\title{
Chemostratigraphy of the Jurassic System: applications, limitations and implications for palaeoceanography
}

\author{
HUGH C. JENKYNS ${ }^{1}$, CHARLES E. JONES ${ }^{2}$, DARREN R. GRÖCKE ${ }^{3}$, STEPHEN P. HESSELBO $^{1} \&$ \\ D. NEIL PARKINSON ${ }^{4}$ \\ ${ }^{1}$ Department of Earth Sciences, University of Oxford, Parks Road, Oxford OX1 3PR, UK \\ (e-mail:hugh.jenkyns@earth.ox.ac.uk) \\ ${ }^{2}$ Department of Geology and Planetary Sciences, 321 Engineering Hall, University of Pittsburgh, Pittsburgh, PA 15260, \\ USA \\ ${ }^{3}$ Department of Geology, Royal Holloway, University of London, Egham Hill, Egham TW20 0EX, UK \\ ${ }^{4}$ Parkinson Geoscience Ltd, 39 Sydney Road, Richmond TW9 1UB, UK
}

\begin{abstract}
Current chemostratigraphical studies of the Jurassic System primarily involve the use of one sedimentary component (marine organic carbon), one divalent transition metal substituted in carbonate (manganese), and two isotopic tracers: strontium-isotope ratios $\left({ }^{87} \mathrm{Sr} /{ }^{86} \mathrm{Sr}\right)$ and carbon-isotope ratios $\left(\delta^{13} \mathrm{C}_{\text {carb }}\right.$ and $\delta^{13} \mathrm{C}_{\text {org }}$ ) in carbonate and in organic matter. Other parameters such as $\mathrm{Mg} / \mathrm{Ca}$ and $\mathrm{Sr} / \mathrm{Ca}$ ratios in calcite, oxygen-isotope ratios $\left(\delta^{18} \mathrm{O}\right)$ in carbonate, sulphur-isotope ratios $\left(\delta^{34} \mathrm{~S}\right)$ in carbonate-hosted sulphate, nitrogenisotope ratios $\left(\delta^{15} \mathrm{~N}_{\mathrm{org}}\right)$ in organic matter, osmium-isotope ratios $\left({ }^{187} \mathrm{Os} /{ }^{188} \mathrm{Os}\right)$ in black shales and neodymiumisotope ratios $\left({ }^{143} \mathrm{Nd} /{ }^{144} \mathrm{Nd}\right)$ in various mineral phases are also useful but at present give poor resolution because the database is incomplete or compromised by various factors. Stratigraphical patterns in total organic carbon (TOC) can be of either local or regional significance, depending on the lateral extent of the former nutrient-rich and productive water mass. Divalent manganese follows a similar pattern, being concentrated, most probably as a very early diagenetic phase, only in oxygen-depleted waters that typically underlie zones of elevated organic productivity. Shifts in $\mathrm{Mg} / \mathrm{Ca}$ and $\mathrm{Sr} / \mathrm{Ca}$ ratios on the time scale of ammonite subzones seem largely to reflect temperature changes. Strontium-isotope ratios from pristine skeletal calcite provide a global signal; $\delta^{13} \mathrm{C}$ values from carbonates with minimal diagenetic overprint potentially do the same, although small spatial differences in palaeo-water-mass composition may have been locally significant. Oxygen-isotope determinations on carbonate rocks and fossils generally yield values that are too scattered to be stratigraphically useful, because they reflect palaeotemperature, the evaporation-precipitation balance in sea water and the impact of any diagenesis involving an aqueous phase. Nitrogen-isotope ratios in organic matter reflect the chemistry of ancient water masses as affected by nitrate utilization and denitrification, and the stratigraphical pattern of this parameter is more likely to correlate only on a regional basis. Neodymiumisotope ratios in sea water are also water mass dependent and greatly affected by regional sources and oceanic current systems. Preliminary data on sulphur-isotope ratios in carbonates and osmium-isotope ratios in organicrich shales, both potentially offering global correlation, indicate that these tracers may be valuable, although the records at present are not sufficiently well established to allow high-resolution regional correlation. In all cases, biostratigraphically well-dated reference sections, against which the relevant geochemical data have been calibrated, are required in the first instance. To date, studies on the stratigraphical distribution of organic carbon have been principally carried out in both northern (Boreal) and southern (Tethyan) Europe; carbonisotope stratigraphy has been undertaken primarily, but not exclusively, on bulk pelagic sediments from the Alpine-Mediterranean or Tethyan domain; and strontium-isotope stratigraphy has been undertaken largely on calcitic skeletal material (belemnites and oysters) from northern and southern Europe. In many sections, including those containing ammonites, multi-parameter chemostratigraphy can give resolution that exceeds that attainable by classic biostratigraphical means. Strontium-isotope ratios in skeletal calcite are a particularly powerful tool for illustrating changes in sedimentary rate and revealing gaps in the stratigraphical record.
\end{abstract}

Keywords: Jurassic, chemostratigraphy, palaeoceanography, strontium isotopes, carbon isotopes, oxygen isotopes, black shales.

A number of geochemical parameters showing stratigraphical variation through the Jurassic have been successfully employed as an aid to correlation and as an index of changing palaeoceanographical conditions. These parameters include the following: total organic carbon (TOC) values of clay-rich sediments; magnesium, manganese and strontium contents of carbonate phases; carbon-isotope ratios of carbonates and organic carbon; oxygen-isotope ratios of skeletal calcites; nitrogen-isotope ratios of organic carbon; sulphur-isotope ratios of carbonate phases; strontium-isotope ratios of skeletal calcites; osmium-isotope ratios in organic-rich mudrocks. The degree of stratigraphical resolution attained varies widely between these different chemical parameters, depending both on intrinsic limitations (degree of isotopic homogeneity of the ocean, residence time of the chemical species in question, rates of chemical change through time, effects of diagenesis) and the quality of current databases. The following account draws on data obtained primarily from British and other European Jurassic sections, where the most 
detailed work has been undertaken, to illustrate the increasing importance of chemostratigraphy as a discipline in its own right. The zonal and subzonal scheme adopted in this account, based on ammonite biostratigraphy, is shown in Fig. 1.

\section{Organic carbon}

Development of organic-rich sediments is dependent on a number of variables such as organic-carbon flux to the sea floor, the length of time organic particles are in contact with oxidizing agents such as dissolved oxygen, nitrate and sulphate, particle size and bulk sedimentary rate (Demaison \& Moore 1980). Adsorption of carbon compounds onto smectitic clay-mineral surfaces may also play a role (Kennedy et al. 2001). Of these variables, organic-carbon flux, directly linked to plankton productivity, is commonly the most important (Pedersen \& Calvert 1990). Within the Jurassic period as a whole, a number of horizons are characterized by anomalously high concentrations of organic carbon, predominantly marine in nature. Most such horizons are traceable across the British Isles and, in some instances, into continental Europe. In one case (Toarcian) the black-shale record is apparently of global distribution.

\section{Triassic-Jurassic boundary}

Sediments close to the Triassic-Jurassic boundary in northern Europe are locally relatively enriched in organic carbon and their facies associations suggest deposition in oxygen-depleted conditions (Hallam 1987, 1995). In one section from Somerset, England, organic-carbon (TOC) values rise to around $10 \mathrm{wt} \%$ in the more shaly lithologies (Cohen \& Coe 2002). In Canada, TOC values rise to $4-5 \mathrm{wt} \%$ from a background of $1-3 \mathrm{wt} \%$ in Triassic-Jurassic boundary sections from Queen Charlotte Islands, British Columbia (Ward et al. 2001). However, stratigraphical definition across the system boundary is too problematic at present to say whether or not relative enrichment in organic carbon is confined to any particular interval.

\section{Sinemurian interval}

Within the semicostatum Zone of the British Sinemurian sequence, a shaly unit, locally dark coloured and organic-carbonrich, is developed in the scipionianum Subzone. In Dorset, this interval is represented by the lower part of the Shales-with-Beef (sensu Hallam 1960); in Somerset it occurs within the Doniford Shales; in Yorkshire it is developed within the Calcareous Shales; and in the Hebrides within the Pabay Shale (e.g. Palmer 1972; Page 1992; Hesselbo \& Jenkyns 1995; Hesselbo et al. 1998).

Fig. 1. Ammonite-based zonal and subzonal scheme, based on Boreal faunas, adopted in this account. The subzonal numbering scheme broadly follows Jones et al. $(1994 b, c)$. Zones with no formal subzonal divisions have been divided into two intervals. Data from Cope et al. (1980a, $b$ ) with modifications from Page (1995) and Callomon \& Cope (1995). It should be noted that a number of non-Boreal zones, mentioned in the text, are not listed here. The differences in Toarcian ammonite zonation across Europe are discussed in the text and illustrated in Fig. 5. With regard to the Oxfordian interval, the Tethyan transversarium Zone probably corresponds to the upper part of the tenuiserratum Zone and the glosense Zone; the glosense Zone should equate with the alternoides Zone of the Russian Platform; the Tethyan bifurcates Zone probably corresponds to the serratum and regulare Zones; the Tethyan bimammatum Zone largely corresponds to the rosenkrantzi Zone (Atrops et al. 1993; Matyja \& Wierbowski 1994).

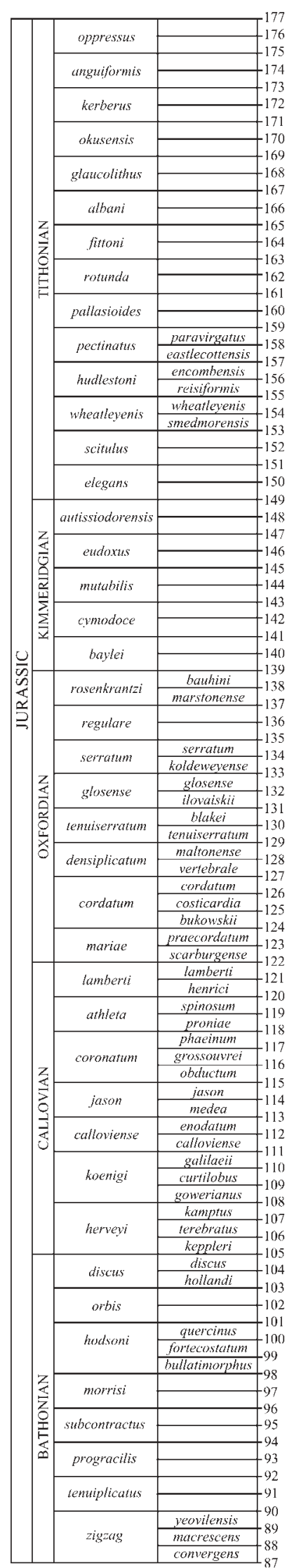


There are no published detailed organic-carbon profiles for these units known to us, but the facies change from underlying lightercoloured, typically coarser-grained clastic sediments into darker shales is striking in all British exposures (Hesselbo \& Jenkyns 1998). An organic-rich shaly horizon of this age can be traced into continental Europe (e.g. Urlichs 1977) and possibly into North and South America (Hallam 1981, 1987); the stratigraphy suggests regional transgression and deepening. In Dorset, black shales with relatively high TOC values extend through the turneri Zone into the obtusum Zone. The chemostratigraphy of the facies developed during Sinemurian time, their regional correlation and palaeoceanographic significance, require further investigation.

\section{Toarcian interval}

The lower Toarcian sequence provides the best-developed and best-documented example of an anomalously carbon-rich shale of regional extent. This is the unit variously known as the Jet Rock in Yorkshire, England, the Posidonienschiefer in northern Germany and Switzerland, and the Schistes Carton(s) in France. Pioneering studies of the stratigraphical variation in TOC and carbon isotopes of carbonate and organic matter in these formations were undertaken by Küspert $(1982,1983)$. Hollander et al. (1991) provided similar data from a core through the Schistes Carton(s) in the Paris Basin, but without the benefit of high-resolution biostratigraphy. Sælen et al. (1996) presented TOC data in a stratigraphical context from the Grey Shales and Jet Rock of Yorkshire. Jenkyns \& Clayton (1997) and Jenkyns et al. (2001) gave detailed TOC profiles through the Jet Rock at Hawsker Bottoms (near Robin Hood's Bay, Yorkshire) and its stratigraphical equivalents in cores from the Mochras (Gwynedd) and Winterborne Kingston (Dorset) Boreholes. The data (Figs. 2 and 3) show clearly that levels of maximum enrichment in organic carbon characterize the lower to middle exaratum Subzone of the falciferum Zone, with highest values in the middle exaratum Subzone in Hawsker Bottoms (10-15 wt $\%$ TOC) and Mochras (2-2.5 wt\% TOC). Zonation is poor over this interval in the Winterborne Kingston Borehole because no ammonites that characterize the tenuicostatum Zone or exaratum Subzone have been found (Ivimey-Cook 1982) and the TOC 'spike' can only be tentatively assigned to the lower falciferum Zone. Detailed chemostratigraphical profiles through the Posidonienschiefer of SW Germany show the same stratigraphical pattern of enrichment in organic carbon (Schmid-Röhl et al. 1999; Röhl et al. 2001) although the zonal scheme is slightly different (maximum TOC, typically 10-15 wt\%, in the elegantulum, exaratum and lowest portion of elegans Subzones, the lower limits of which are based on the first appearances of the index species, together corresponding to the lower to middle exaratum Subzone in England (Howarth 1992)).

Organic-rich shales are also represented within the Abnormal Fish Bed (exaratum Subzone) of Northamptonshire and Oxfordshire, and as the Portree Shales (possibly top of tenuicostatum Zone; middle and upper exaratum Subzone) in the Hebrides (Howarth in Cope et al. 1980a; Howarth 1992). They are also developed offshore in the southern North Sea (Riegraf et al. 1984; Fleet et al. 1987) and the North Celtic Sea (Murphy et al. 1995). They are absent on the Dorset coast, where only the upper part of the exaratum Subzone is proved (Howarth 1992) and much of the Toarcian sequence is condensed into the pinkcoloured calcareous-ferruginous Junction Bed (Howarth in Cope et al. 1980a; Jenkyns \& Senior 1991).

The lower Toarcian organic-carbon-rich shales are unique in the Jurassic sequence because their distribution is effectively global (Fig. 4). Additional examples are known from central and southern Europe (where the black shales are commonly intimately associated with manganese carbonates), north Africa, the Middle East, Siberia, Madagascar, offshore Australia, North and South America and Japan (Guex 1973; Jenkyns 1988; Baudin et al. 1990; Jenkyns et al. 1991; Leith et al. 1992; Nikitenko \& Shurygin 1992; Jenkyns et al. 2001). Their deposition has been attributed to the impact of an Oceanic Anoxic Event, a phenomenon causing excess carbon burial, probably triggered by an increase in productivity of organic-walled and siliceous plankton, across a range of marine environments that consequently became poorly oxygenated (Jenkyns 1999). In North America, Japan and Madagascar the likely age of the organicrich facies is tenuicostatum-falciferum Zone (Jenkyns 1988). In one locality in Japan, Toarcian carbon-rich shales, attributed to the Oceanic Anoxic Event, occur within an allochthonous sequence of radiolarian cherts, derived from the former Pacific Ocean (Hori 1997). This important occurrence shows that organic-rich sediments were deposited in the deep oceans as well as on continental margins and shelf seas, and underscores the global significance of this event.

In the Southern Alps of Italy, the carbon-rich black shales (TOC values typically $1-5 \mathrm{wt} \%$, Jenkyns et al. 2001) are locally interbedded with manganoan carbonates; the sequences are attributed to the falciferum Zone and possibly the tenuicostatum Zone (Jenkyns et al. 1985). However, elsewhere in Italy it has been argued that these characteristic facies could be somewhat older. For example, in the Marche-Umbria region of Italy, the black carbon-rich shales are attributed to the interval between the middle tenuicostatum Zone and lower serpentinus Zone, most probably lying entirely within the tenuicostatum Zone (Bucefalo Palliani \& Mattioli 1994; Monaco et al. 1994; Nini et al. 1996; Parisi et al. 1996). These age assignments are based, at least in part, on ammonite faunas. If we take the TOC maximum as a time-constant horizon, a partial equivalence between the exaratum Subzone of the English Boreal province and the tenuicostatum Zone, as identified in Marche-Umbria, is thus implied (Bucefalo Palliani \& Mattioli 1994; Jenkyns \& Clayton 1997).

According to Nini et al. (1996) and Parisi et al. (1996), the base of the serpentinus Zone in the Italian Apennines is defined by the first occurrence of Hildaites. In the English sections studied by Howarth (1992), however, this form appears midway through the exaratum Subzone, effectively coincident with the upper stratigraphical limit of the TOC maximum (Jenkyns \& Clayton 1997). It seems therefore that, if the first occurrence of Hildaites provides a reliable marker across northern and southern Europe, the palaeontological data and chemostratigraphical data are in perfect agreement (Fig. 5).

In the Subbetic sections of southern Spain, the black shales, whose few TOC values are $c .1 \mathrm{wt} \%$, are ascribed to the upper part of the polymorphum Zone (assumed to largely correlate with the tenuicostatum Zone) and the lower part of the serpentinus Zone (Jiménez et al. 1996). Again, using the same argument, there may be some equivalence in time between the upper part of the polymorphum Zone in the Subbetic of Spain and the exaratum Subzone of the British Boreal province. Some Italian workers also use the polymorphum Zone rather than the tenuicostatum Zone, the base of which is similarly defined by the appearance of the first Dactylioceras; and the levisoni Zone rather than the serpentinus Zone, again similarly defined by the first appearance of Hildaites (Parisi et al. 1998). This zonation, applied to the Marche-Umbrian Apennines and parts of western Greece (Ionian Zone), places the organic-rich black shales in the middle to upper part of the polymorphum Zone (Pettinelli et al. 

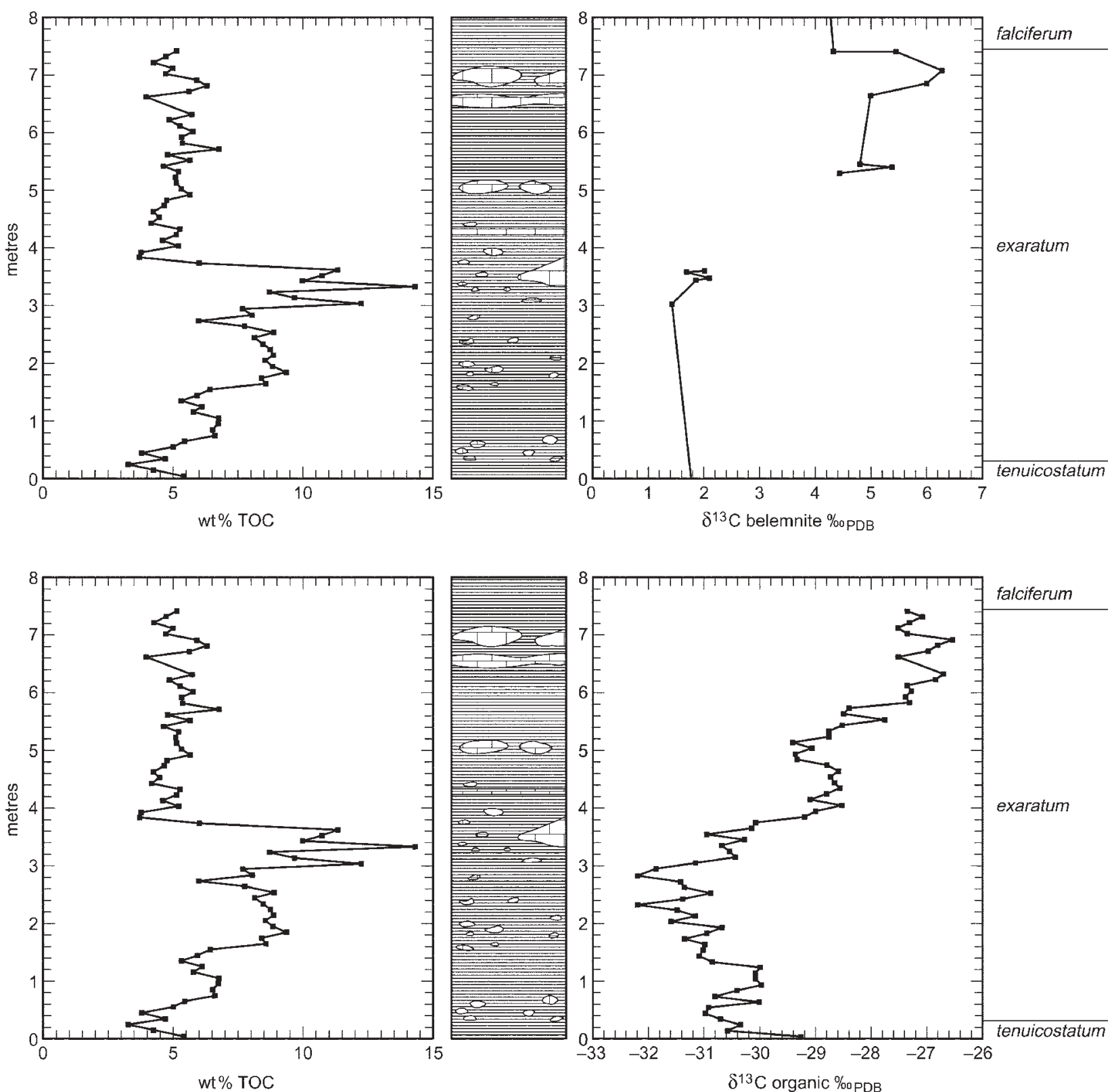

\begin{tabular}{|c|c|}
\hline 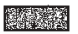 & Dark marl \\
\hline$\square$ & Medium marl \\
\hline$\square$ & Light marl \\
\hline 言 & Laminated Shale \\
\hline$=$ & Mudstone \\
\hline$\therefore \because$ & Sandstone \\
\hline בبـ & Limestone \\
\hline$\infty$ & Carbonate concretions \\
\hline$\triangle \Delta \triangle$ & Crinoid Concentrations \\
\hline$\rightarrow \infty$ & Belemnite Concentrations \\
\hline$\rightarrow$ & Tabular cross-bedding \\
\hline 5 & Soft-sediment deformation \\
\hline & Pyrite nodules \\
\hline
\end{tabular}

Fig. 2. Bio- and chemostratigraphy $\left(\delta^{13} \mathrm{C}_{\text {belemnites }}\right.$ and $\delta^{13} \mathrm{C}_{\text {org }}$ v. total organic carbon (TOC)) for lower Toarcian sequence (Jet Rock), Hawsker Bottoms, near Robin Hood's Bay, Yorkshire, England. It should be noted how the highest values of organic carbon and lowest values of $\delta^{13} \mathrm{C}_{\mathrm{org}}$ characterize the lower half of the exaratum Subzone, as defined in Britain. Relative maxima in $\delta^{13} \mathrm{C}_{\text {belemnites }}$ and $\delta^{13} \mathrm{C}_{\text {org }}$ are characteristic of the upper exaratum Subzone. Data from Howarth (1962, 1992), Jenkyns \& Clayton (1997) and Jenkyns et al. (2001). Belemnite data are from Sælen et al. (1998) and come from several localities along the Yorkshire coast. Key to lithological symbols in this figure and for Figs. 3, 6, 8, 9, 12 and 13 also shown. 

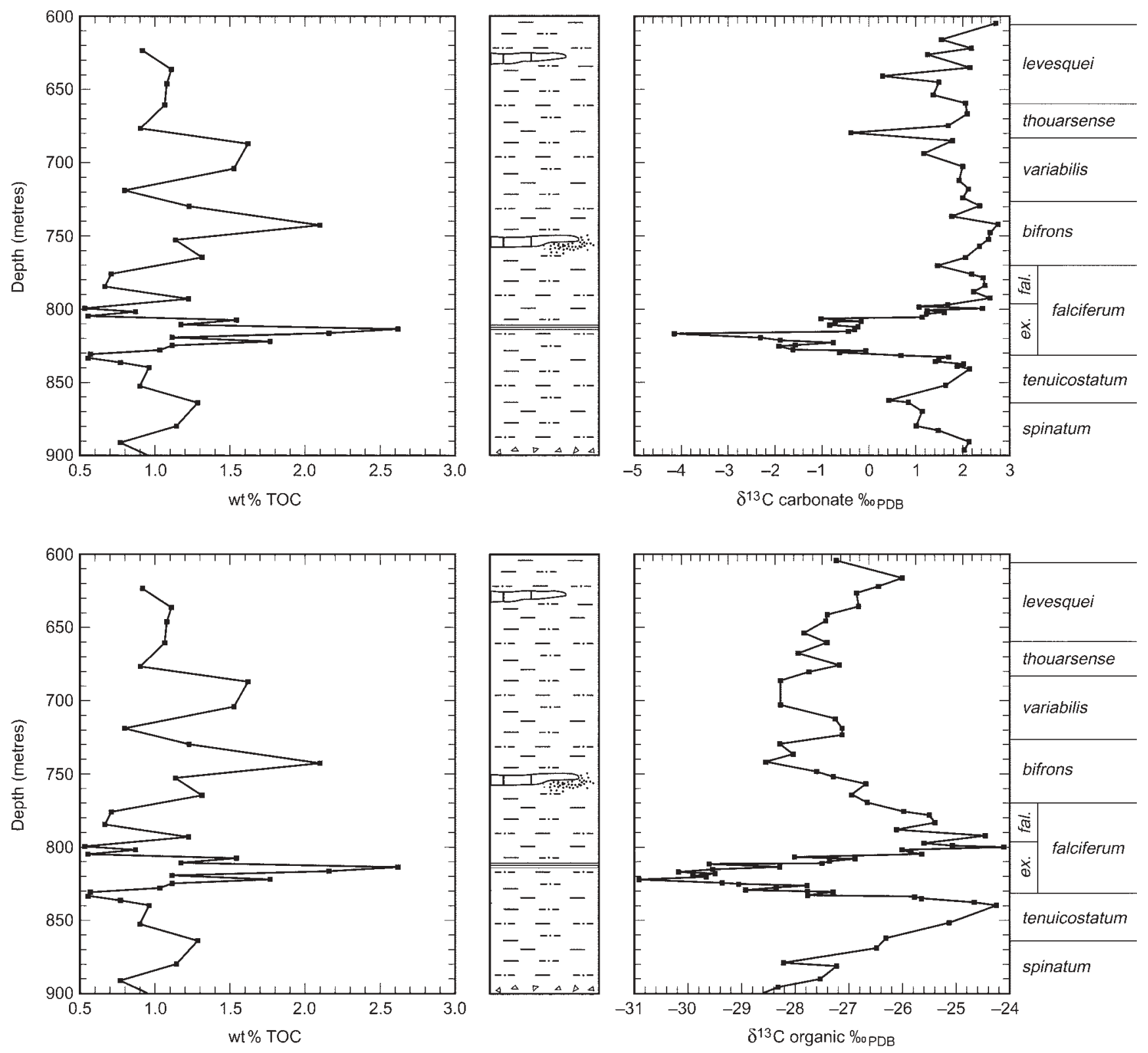

Fig. 3. Bio- and chemostratigraphy $\left(\delta^{13} \mathrm{C}_{\text {carbonate }}\right.$ and $\delta^{13} \mathrm{C}_{\text {org }}$ v. TOC) for the lower Toarcian sequence, Mochras Borehole, Gwynedd, Wales. It should be noted how the highest values of organic carbon characterize the lower half of the exaratum Subzone, as is the case in Yorkshire, although the absolute values are much lower. Relative minima in $\delta^{13} \mathrm{C}_{\text {carbonate }}$ and $\delta^{13} \mathrm{C}_{\text {org }}$ also characterize this interval. It should be noted particularly how the negative $\delta^{13} \mathrm{C}_{\text {org }}$ excursion interrupts a broader positive excursion. These relationships, and those illustrated in Fig. 2, are interpreted as the response to major changes in global carbon cycling, particularly burial of excess planktonic organic matter and release of gas hydrates (Jenkyns 1988, 1999; Hesselbo et al. 2000a). Data from Ivimey-Cook (1971), O’Sullivan et al. (1971), Jenkyns \& Clayton (1997) and Jenkyns et al. (2001). Lithological symbols as in Fig. 2.

1995). In one Greek section on Lefkas Island, analytical data show highest TOC values (c. $0.6-0.7 \mathrm{wt} \%$ ) in the upper part of the black-shale section attributed to the higher part of the polymorphum Zone. TOC values in lower Toarcian sections elsewhere in Greece are similarly low, typically not exceeding $2 \mathrm{wt} \%$ (Baudin \& Lachkar 1990). Again, this pattern is consistent with a coeval TOC maximum across northern and southern (Tethyan) Europe (Fig. 5). In Hungary, the organic-rich shales (TOC typically $0.5-4.5 \mathrm{wt} \%$ ) and associated ore-grade manganoan carbonates are referred to the tenuicostatum and early falciferum Zones (Jenkyns et al. 1991; Dulai et al. 1992; Vetö et al. 1997).
To summarize: the TOC maxima in the British and German sections and the principal level of black carbon-rich shales in the Alpine-Mediterranean domain can be everywhere assigned to the lower to middle exaratum Subzone in terms of the Boreal (British) ammonite zonation (Fig. 5) or its equivalents. Even though organic-carbon values are much higher in northern than Tethyan Europe (Jenkyns 1985), the implication is that, across the whole of this region, the productivity and burial of planktonic organic matter was most pronounced during this interval of early Toarcian time. Increases in productivity imply increases in nutrient availability in the photic zone, probably linked to major changes in climate, in turn probably forced by excess volcano- 


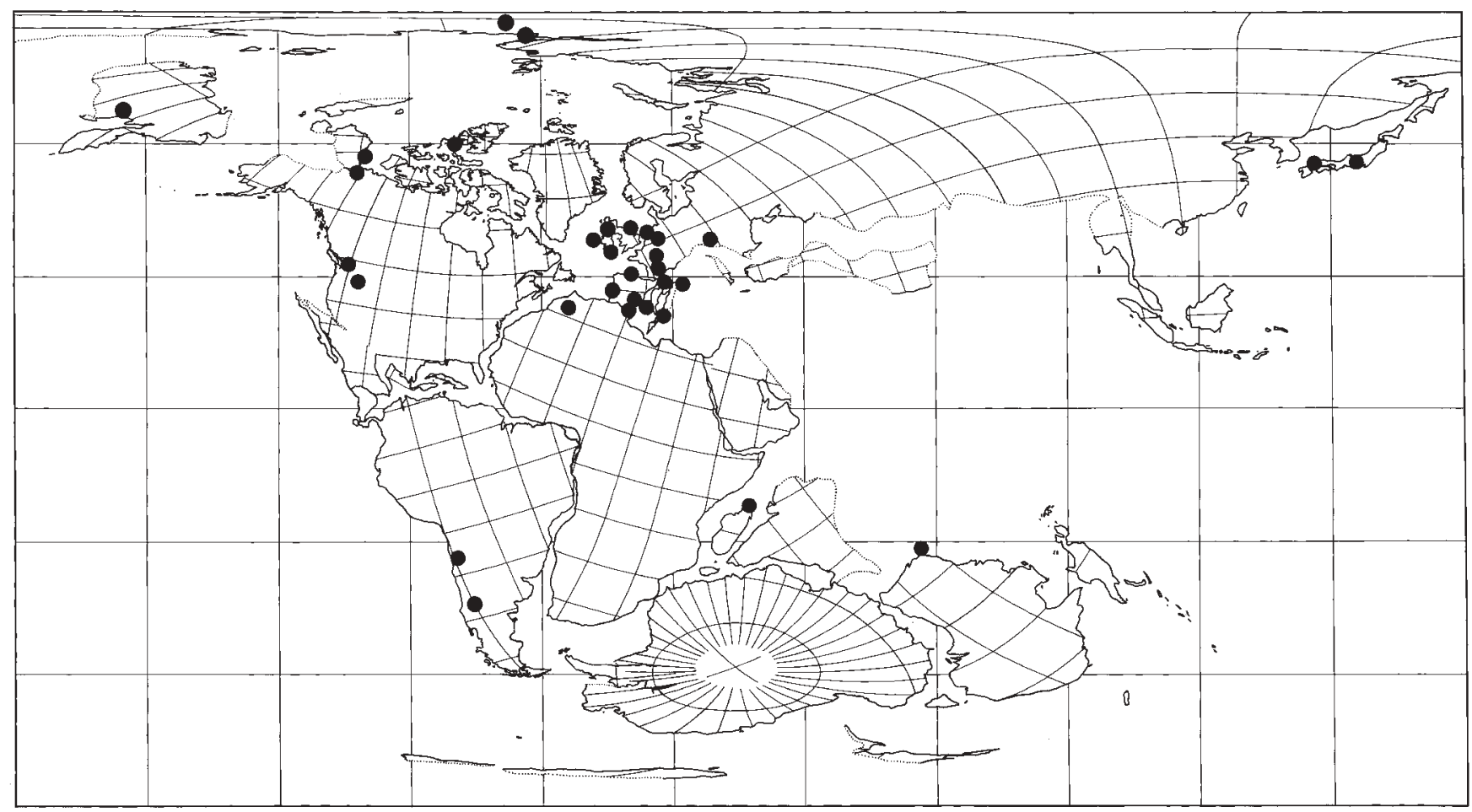

Fig. 4. Global distribution of Toarcian black shales. In the majority of cases, the carbon-rich sediments are dated as tenuicostatum/polymorphum to falciferum/serpentinus/levisoni Zones according to the zonal scheme adopted. Modified from Jenkyns (1988) with additions from Guex (1973), Baudin et al. (1990), Soussi et al. (1990), Dulai et al. (1992), Howarth (1992), Nikitenko \& Shurygin (1992), Bucefalo Palliani \& Mattioli (1994), Murphy et al. (1995), Jiménez et al. (1996), Parisi et al. (1996), Hori (1997) and Vetö et al. (1997). This remarkable global distribution of carbon-rich sediment is attributed to the impact of an Oceanic Anoxic Event fostered by increased production and burial of planktonic organic matter (Jenkyns 1988, 1999).

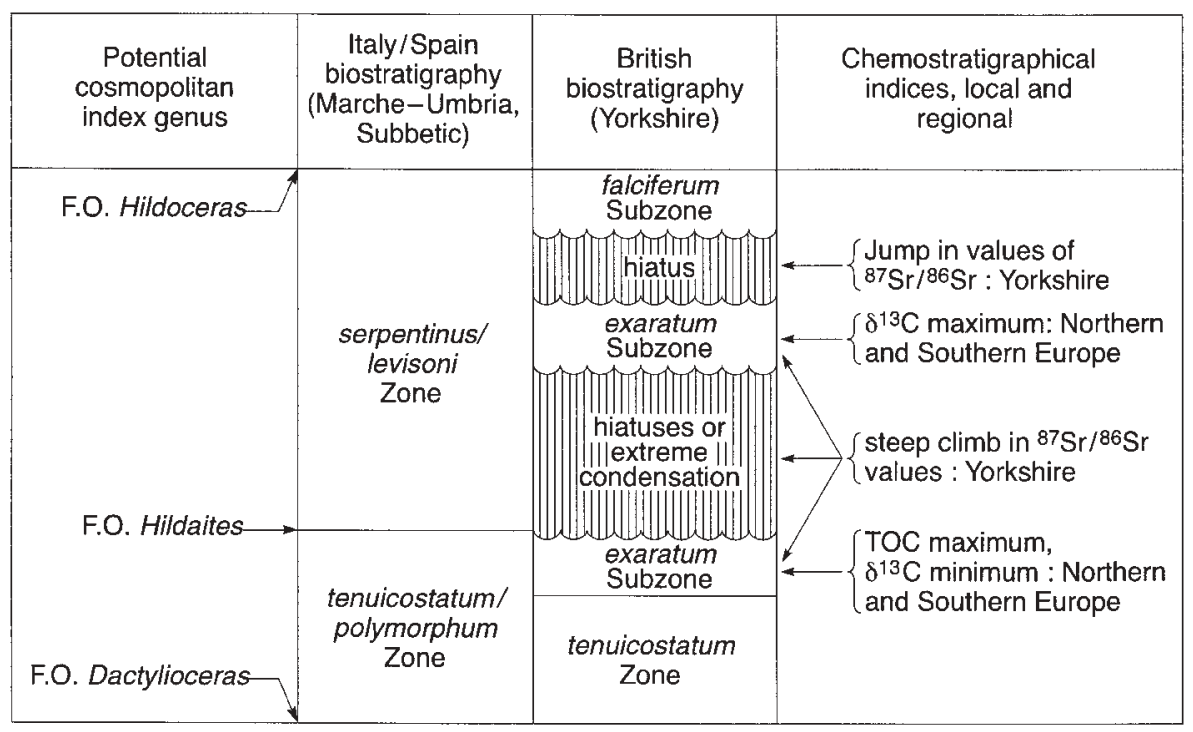

Fig. 5. Comparison between biostratigraphical schemes in Britain (Yorkshire) compared with Italy and Spain. It should be noted that the end of the tenuicostatum Zone is clearly diachronous. The first occurrence of Hildaites, which defines the base of the serpentinus Zone in the Tethyan region, appears midway through the exaratum Subzone in Britain, hence the black shales with the highest TOC fall into the tenuicostatum Zone in Italy and Spain and lower part of the exaratum Subzone of the falciferum Zone in Britain. Data from Howarth (1992), Jiménez et al. (1996), Nini et al. (1996) and Jenkyns \& Clayton (1997). Local strontiumisotope events for the Yorkshire section, indicating the presence of condensed sections and hiatuses, are also indicated. genic carbon dioxide (Jenkyns 1999; Pálfy \& Smith 2000; Jones \& Jenkyns 2001). Regional deepening during the falciferum Zone is established for many areas of the globe (Hallam 1981; Jenkyns 1988; Hesselbo \& Jenkyns 1998).

\section{Callovian interval}

In Britain, the Oxford Clay, of mid-Callovian to early Oxfordian age, crops out between Dorset and Yorkshire. It is organic-rich in its lower levels (jason, coronatum and athleta Zones) where exposed in the English Midlands (Morris 1980; Hudson \& Martil 1991). Organic-carbon values rise above the mid-Callovian background (c. $4 \mathrm{wt} \%$ TOC) in both the lower jason Subzone and the mid-phaeinum Subzone, where values locally attain $15 \mathrm{wt} \%$ (Kenig et al. 1994). Hudson \& Martil (1991) favoured relatively high productivity of marine phytoplankton as the major source of organic matter. The Dunans Shale of the Isle of Skye, with TOC values in the $4-10 \mathrm{wt} \%$ range, is also of jason and coronatum 
Zone age; the overlying Dunans Clay, pertaining to the athleta and lamberti Zones, has few TOC values exceeding $2 \mathrm{wt} \%$ (Cope et al. 1980b; Fisher \& Hudson 1987). There are no highresolution studies of the regional extent of these carbon-rich levels, largely because of paucity of exposure, and they may well be local to the British Isles. Callovian facies are not organic rich in the North Sea, Paris Basin and the western Subalpine region of France (e.g. Espitalié et al. 1987; Dromart et al. 1989). In the Vocontian Trough of SE France the so-called 'Terres Noires' comprise a $>1 \mathrm{~km}$ section of black shales of BathonianCallovian-Oxfordian age whose TOC values, in its upper portion, range between 0.5 and $1.5 \mathrm{wt} \%$ (Tribovillard 1988; de Graciansky et al. 1998), but high-resolution chemostratigraphy is not established. Poorly dated Callovian black shales are known from the Middle East (Bein \& Binstock 1985; Stoneley 1987; Carrigan et al. 1995) and the western central Atlantic (Robertson \& Ogg 1986).

\section{Oxfordian interval}

The only known organic-rich deposit in the Oxfordian of the British area is the Flodigarry Shale on the Isle of Skye, whose basal portion is dated as pertaining to the tenuiserratum and glosense Zones. This organic-rich interval apparently has some lateral continuity outside the British Isles, although the zonal schemes are difficult to cross-correlate because of the provincial nature of Oxfordian ammonites (Jenkyns 1996). In the central Russian Platform, for example, the tenuiserratum Zone and the proposed equivalent to the glosense Zone (the alternoides Zone) are represented by deep-marine organic-rich clays (Sahagian et al. 1996). In the Himalayan region, the Spiti Shale and its correlatives, which crop out over a distance $>1500 \mathrm{~km}$, are black and carbon rich, and locally dated as transversarium Zone. This Tethyan ammonite zone is correlated in part with the tenuiserratum and glosense Zones (Atrops et al. 1993; Matyja \& Wierbowski 1994). Other Oxfordian black shales are documented from SE France (Terres Noires), North Sea, Greenland, Alaska, Svalbard, western Siberia, western Atlantic, Gulf of Mexico and the Middle East, but dating is generally poor (Tribovillard 1988; Leith et al. 1992; Carrigan et al. 1995; Fowler \& McAlpine 1995). The sedimentary evidence from these and other localities suggests regional deepening and transgression during the tenuiserratum-glosense-transversarium Zones (Jenkyns 1996).

\section{Kimmeridgian-Tithonian interval}

Across the British area, five organic-rich bands have been previously recognized as traceable within the black organic-rich shale succession of the Kimmeridge Clay (Gallois 1978; Herbin \& Geyssant 1993; Herbin et al. 1995). Examples occur in the middle of the eudoxus Zone, the upper part of the eudoxus and lower part of autissiodorensis Zones, the elegans Zone, the upper part of the wheatleyensis and the lower part of the hudlestoni Zones, and the upper part of the hudlestoni and lower part of the pectinatus Zones. These horizons can be traced from Dorset to Yorkshire and into the North Sea area: they are characteristic of NW Europe (Herbin et al. 1993). A high-resolution (composite sample, every $20 \mathrm{~cm}$ ) organic-carbon stratigraphy for the type Kimmeridge Clay of Dorset is illustrated in Fig. 6: as well as the horizons alluded to above, relatively high TOC values are also registered in black shales from the scitulus Zone. Throughout the succession there are subsidiary peaks in TOC, clearly seen in the mutabilis, lower eudoxus and pallasioides Zones where background values are relatively low. Some of these TOC maxima represent parts of metre-scale sedimentary cycles but others are indicative of more stratigraphically extensive departures from background values (Morgans-Bell et al. 2001). From the base of the section up to the wheatleyensis-hudlestoni Zones there is an increase in the amplitude of the broader TOC peaks or bands and a decline stratigraphically above. Against this background, up to eight or nine (according to whether the two stratigraphically highest peaks are grouped together or not) organic-rich bands may be recognized (Fig. 6).

In the Boulonnais region of France, where the succession contains intercalations of shallow-water sands, only the lower part of autissiodorensis Zone and the elegans Zone are characterized by carbon-rich clays (Herbin et al. 1995).

In Dorset, a horizon known as the Blackstone Band (Fig. 6) occurs exactly at the top of the wheatleyensis Zone and its upper boundary hence defines the base of the hudlestoni Zone (Cope $1967,1974)$. This unit is extraordinarily rich in organic carbon (>50 wt\% TOC in some parts, Huc et al. 1992; Herbin et al. $1995)$ and readily recognizable in the field and in downhole logs (Cox \& Gallois 1981; Herbin et al. 1993). As well as being well displayed in its type locality in Dorset, this horizon can also be recognized in boreholes in the region of the Wash, eastern England (Gallois \& Cox 1974) and in boreholes in the Vale of Pickering, Yorkshire, and in the North Sea (Herbin et al. 1993). There has been considerable debate as to whether the richness in organic matter of the Kimmeridge Clay relates primarily to enhanced productivity or enhanced preservation, with most workers favouring productivity of planktonic organic matter as the first-order control (e.g. Huc et al. 1992; Ramanampisoa \& Disnar 1994; Tribovillard et al. 1994; Sælen et al. 2000). In this context the formation of the Blackstone must imply the former presence of extremely nutrient-rich and fertile surface waters in parts of northern Europe in latest wheatleyensis Zone time. The time of deposition of this unit corresponds to an extremely rapid rise in palaeotemperature and aridity, as determined by palynological data from the southern North Sea (Abbink et al. 2001), and a relative increase in silt-grade quartz (Williams et al. 2001) in the type locality of the Kimmeridge Clay; these associations are difficult to place in any coherent palaeoceanographic model.

Tracing Kimmeridgian-Tithonian and other organic-rich lithologies, at the highest levels of biostratigraphical resolution, outside the confines of the British and adjacent areas has not proven successful. In the Volga Basin, for example, Kimmeridgian-Volgian organic-rich facies are of different ages (cymodoce and upper rotunda Zones, Hantzpergue et al. 1998). This suggests that individual basins had their own palaeoceanography. In general, Kimmeridgian-Tithonian organic-rich facies are relatively widespread in a global context, being known from South America, western North America, Antarctica, parts of the Atlantic Ocean, Svarlbard, East Greenland, Barents Sea, western Siberia and the Middle East (Farquharson 1983; Dypvik 1985; Stein et al. 1986; Hallam 1987; Stoneley 1987; Surlyk 1987; Leith et al. 1992; Fowler \& McAlpine 1995). In Svalbard, organic-carbon values of Upper Jurassic laminated black shales (Janusfjellet Formation) reach almost $12 \mathrm{wt} \%$ at some levels (Hvoslef et al. 1985). In all, cases, however, stratigraphical resolution is poor. In southern (Tethyan) Europe, Kimmeridgian-Tithonian facies are not generally enriched in organic matter (apart from a possible poorly dated exception described by Danelian \& Baudin 1990) and red radiolarian cherts are commonly developed (de Wever \& Baudin 1996; Bombardiere \& Gorin 2000). Unlike the Toarcian sequence, there is no evidence for a widespread Kimmeridgian Oceanic Anoxic Event. 


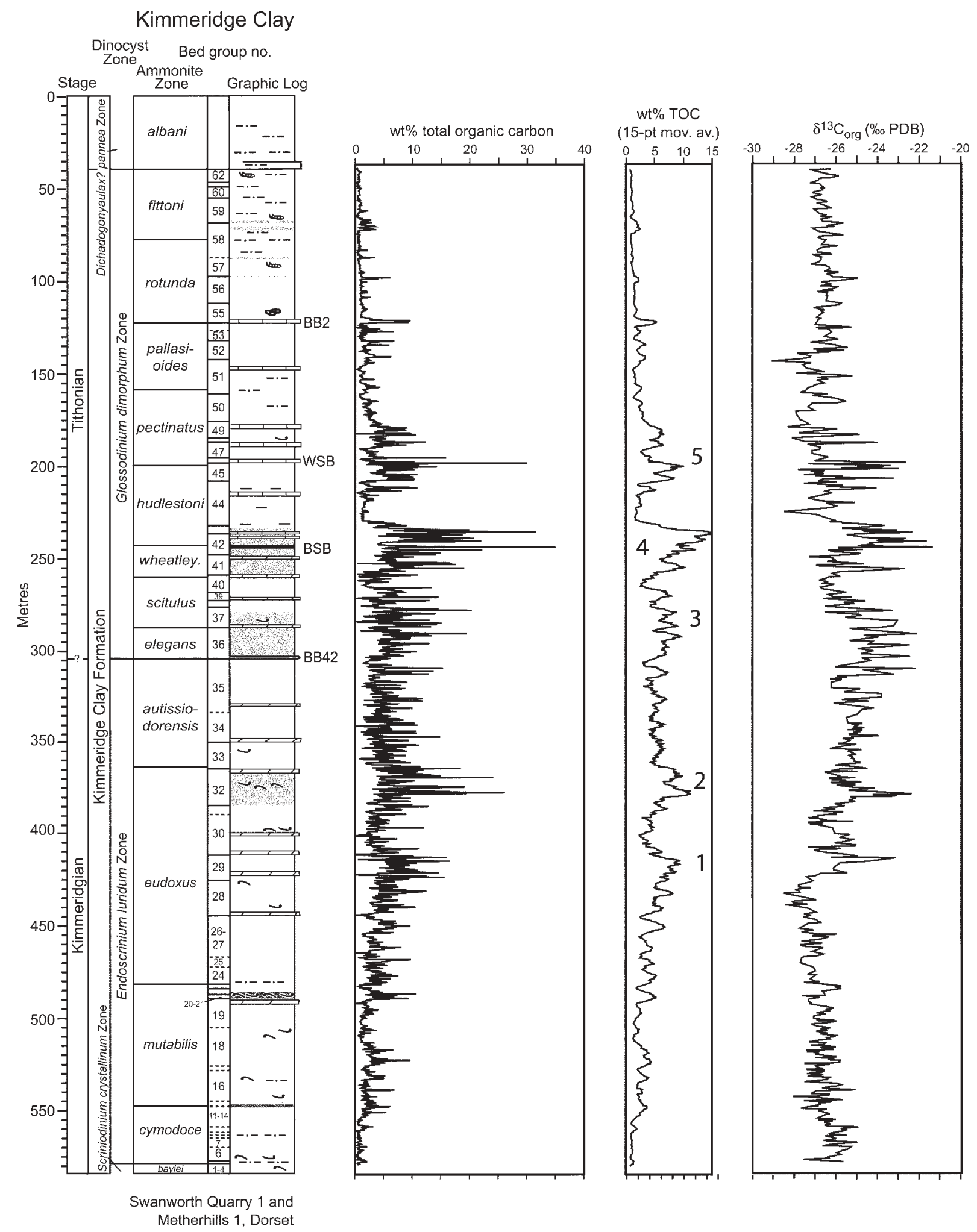

Fig. 6. Organic-carbon and carbon-isotope curves $\left(\delta^{13} \mathrm{C}_{\mathrm{org}}\right)$ and proposed bed numbers for the Kimmeridge Clay, Dorset, England, after Morgans-Bell et al. (2001) and data from the Kimmeridge Drilling Project web site (http://kimmeridge.earth.ox.ac.uk). Note the five major, and several minor peaks in TOC. Smoothed data (15-point moving average) illustrate the five TOC-rich bands particularly clearly. Also noteworthy is the overall fall in $\delta^{13} \mathrm{C}_{\text {org }}$ values from the baylei to the mid-eudoxus Zone, followed by a distinct shift to higher values and an isotopic profile punctuated by a number of positive excursions, generally correlative with high TOC values. The prominent excursion centred on the Blackstone Band (BSB) and the White Stone Band (WSB) should be noted. The $\delta^{13} \mathrm{C}_{\text {org }}$ profile becomes distinctly less 'spiky' above the pallasioides Zone and is similar in character to that in the lowest part of the section. BB42 signifies Blake's Bed 42, tentatively fixed as the Kimmeridgian-Tithonian boundary; BB2 (minor TOC peak) signifies Blake's Bed 2. Detailed biostratigraphy has been given by Callomon \& Cope (1995). Lithological symbols as in Fig. 2. 


\section{Trace elements (magnesium)}

The most important controls on the content of magnesium substituted into the calcite lattice precipitated or secreted from sea water are composition of the enclosing fluid, particularly with respect to $\mathrm{Mg} / \mathrm{Ca}$ ratio, and temperature, given that there are also species-dependent vital effects (e.g. Chave 1954; Katz 1973; Berner 1975; Mucci 1987). The Mg content of sea water is largely controlled by the balance between rates of fluvial supply and rates of removal into both biogenic carbonates and hot basalt during hydrothermal reactions at spreading ocean ridges (Wilkinson \& Algeo 1989). Bulk carbonate geochemistry on pelagic carbonates of latest Jurassic-Cretaceous age has yielded rather scattered Mg data (Renard 1986). By contrast, skeletal calcite offers promise, as shown by the recent application of $\mathrm{Mg}$ / $\mathrm{Ca}$ stratigraphy and palaeothermometry utilizing Cenozoic benthic foraminifera (Lear et al. 2000). Mg/Ca palaeothermometry based primarily on belemnites, however, predates this study by several decades. Although there is petrographical evidence for repeated changes in precipitated carbonate mineralogy through Phanerozoic time, probably dependent on variations in marine $\mathrm{Mg} / \mathrm{Ca}$ ratios among other factors (Sandberg 1985), the available record when coupled with modelling studies (Wilkinson \& Algeo 1989) implies that such changes took place over time scales of many millions of years. Hence temperature change is the most likely factor controlling short-term (duration of ammonite zones or subzones) changes in the $\mathrm{Mg} / \mathrm{Ca}$ ratios in Jurassic skeletal carbonates. Data on $\mathrm{Mg} / \mathrm{Ca}$ ratios in belemnites, brachiopods and bivalves assembled by researchers in the former Soviet Union (Berlin et al. 1967; Yasamanov 1981) indicate relatively high temperatures in early Toarcian time and relatively low temperatures in the Oxfordian-Kimmeridgian interval. The detailed chemostratigraphical study of belemnites from the Toarcian sequence of Yorkshire places the abrupt $\mathrm{Mg} / \mathrm{Ca}$ increase across the tenuicostatum-falciferum Zone boundary and the maximum in the mid-exaratum Subzone (McArthur et al. 2000a). Data from belemnites collected from northern Spain show a similar $\mathrm{Mg} / \mathrm{Ca}$ increase across the tenuicostatum-falciferum Zone boundary (Rosales et al. 2001). Although at present there is little high-resolution work on $\mathrm{Mg} / \mathrm{Ca}$ ratios in belemnites, and certainly no single-species investigations, this parameter may in future be of some use in local correlation when coupled with other geochemical tracers: the prerequisite, obviously, is for the fossils in question to have inhabited water masses with the same temperature structure. However, long time-series derived from widely separated localities across a range of palaeolatitudes could potentially indicate global climate change, even though absolute values of the $\mathrm{Mg} / \mathrm{Ca}$ ratio for any particular interval would vary from place to place.

\section{Trace elements (manganese)}

The relative abundance of the carbonate-bound redox-sensitive element manganese has been explored with respect to the stratigraphy of certain Jurassic strata. The most significant example in Europe is the lower Toarcian sequence where, locally underlying or interbedded with carbon-rich shales, are beds of manganoan carbonates, attributed to the falciferum Zone and possibly the tenuicostatum Zone (Jenkyns et al. 1985): these mineral deposits are another sedimentary manifestation of the Oceanic Anoxic Event and are widespread in Central Europe (Austria, Germany, Hungary, Italy, Slovakia). The metal-rich carbonates belong to the system $\mathrm{CaCO}_{3}-\mathrm{MgCO}_{3}-\mathrm{MnCO}_{3}-$ $\mathrm{FeCO}_{3}$, and the relative concentrations of the different divalent cations are highly variable; in Hungary the deposits are economically viable, as has been the case elsewhere in Europe in the past. Although the source of the metals may be either continental or hydrothermal, transport of the relatively soluble $\mathrm{Fe}^{2+}$ and $\mathrm{Mn}^{2+}$ species was undoubtedly facilitated by the presence of a laterally extensive dysoxic to anoxic water column. The manganese-rich phases have been interpreted as early diagenetic (Polgári et al. 1991).

The stratigraphical distribution of acid-soluble manganese in the Winterborne Kingston section of Dorset shows a 'spike' in the cored section just below the TOC maximum in the basal falciferum Zone, where $\mathrm{Mn}$ values rise to a value in excess of $4000 \mathrm{ppm}$ from a background of about $2000 \mathrm{ppm}$ (Jenkyns, unpublished data). Manganese stratigraphy has also been employed in studies of the Jurassic pelagic carbonates of SE France by Corbin et al. (2000). Those workers documented major manganese excursions to higher values (typically from a background of a few hundred ppm to over $1000 \mathrm{ppm}$ ) in the upper Pliensbachian, lower Bathonian, upper Callovian (athleta and lamberti Zones) and Oxfordian sequences (transversarium and bifurcatus Zones). Two smaller-scale events in the humphriesianum and garantiana Zones of the Bajocian interval are also recorded. Similar relatively high manganese values are also recorded from the Kimmeridgian sequence of the same region (de Rafelis et al. 2001). The regional applicability of this local manganese stratigraphy is not established, although Corbin et al. (2000) attributed the elevated values to episodes of hydrothermal activity in the Tethys and Atlantic that affected the chemistry of global sea water. Clearly, however, the fact that some manganese may reside in or on clay-mineral species will complicate simple acid-soluble-manganese stratigraphy on bulk carbonates. Furthermore, the requirement for oxygen-depleted water masses to facilitate the advection of divalent manganese shows that its use as a chemostratigraphical index in carbonate sediments may be essentially regional except, perhaps, during an Oceanic Anoxic Event. In addition, the possibility of late diagenetic addition of $\mathrm{Mn}$ to carbonate phases has to be eliminated if manganese stratigraphy is to be meaningful.

\section{Trace elements (strontium)}

Strontium is principally supplied to the oceans by rivers and hydrothermal systems on and around oceanic spreading centres and removed by incorporation in biogenic carbonates, particularly skeletal aragonite whose $\mathrm{Sr} / \mathrm{Ca}$ ratio is $2-6$ times that of calcite (Graham et al. 1982). Diagenesis and dissolution of carbonates will add an additional flux to the oceans. Incorporation of strontium into biogenic calcites (planktonic foraminifera, coccoliths) is governed by the $\mathrm{Sr} / \mathrm{Ca}$ ratio of the sea water from which they were secreted as well as by temperature, salinity, $\mathrm{pH}$ and other environmental and biological effects governing calcification rate (e.g. Lea et al. 1999; Stoll \& Schrag 2000). Changes in the strontium flux to the oceans can be produced by decrease in the global fixation rate of shallow-water aragonitic material, linked to drowning of carbonate platforms and reefs or largescale meteoric-water diagenesis of shelf carbonates during eustatic sea-level fall (Graham et al. 1982; Schlanger 1988; Stoll \& Schrag 2001). Changes in $\mathrm{Sr} / \mathrm{Ca}$ ratios in deep-sea carbonates through time have been demonstrated for the Cenozoic period (Graham et al. 1982; Stoll \& Schrag 1998), and studies on bulk Mesozoic pelagic carbonates from oceans and outcrops reveal considerable long-term variation in this parameter (Renard 1986; Stoll \& Schrag 1996, 2001). In Cretaceous deep-sea carbonates, $\mathrm{Sr} / \mathrm{Ca}$ ratios show stratigraphically reproducible trends (Stoll \& 
Schrag 1996) whereas data from outcrops of coeval pelagic limestones from Italy and Spain correlate less well (Stoll \& Schrag 2001); these latter facies, however, contain variable amounts of clay and even careful treatment before dissolution may not have removed all strontium substituted in phases other than calcite. In the case of cyclically bedded claystones and limestones from the Atlantic Cretaceous units, primary trends in $\mathrm{Sr} / \mathrm{Ca}$ ratios have been substantially modified during burial diagenesis by movement of calcium carbonate from clay-rich to clay-poor sediments (T.D. Frank et al. 1999).

Bulk-carbonate data from the Jurassic sequence cover only its uppermost interval and reproducible trends have yet to be demonstrated (Renard 1986). Sr/Ca ratios from belemnites spanning the Pliensbachian-Toarcian boundary from Yorkshire increase across the tenuicostatum-falciferum Zone boundary, correlative with a rise in $\mathrm{Mg} / \mathrm{Ca}$ ratios and a decrease in $\delta^{18} \mathrm{O}$ ratios (McArthur et al. 2001a). Although a rise in water temperature during exaratum Subzone time could explain all these geochemical trends, the complexity of the $\mathrm{Sr} / \mathrm{Ca}$ system in biogenic carbonates implies that other factors must also be considered. It is notable, for example, that widespread disintegration and drowning of Tethyan carbonate platforms took place around Pliensbachian-Toarcian boundary time (Bernoulli \& Jenkyns 1974) and this loss of shallow-water sites would have decreased secretion and precipitation of aragonite and hence increased the $\mathrm{Sr} / \mathrm{Ca}$ ratio in sea water.

Overall, it seems that $\mathrm{Sr} / \mathrm{Ca}$ ratios in Jurassic skeletal calcites, carefully screened for the effects of diagenesis, might have potential for at least local stratigraphical correlation whereas bulk carbonates, with their ubiquitous component of clay, remain more problematic.

\section{Carbon isotopes}

Carbon-isotope stratigraphy began with the pioneering work of Scholle \& Arthur (1980) on Cretaceous pelagic carbonates. They pointed out that, although the $\delta^{13} \mathrm{C}$ composition of Recent oceans was water mass dependent to a degree and varied both vertically and laterally, intercontinental correlation of pelagic carbonates was possible for those parts of the record characterized by distinctive excursions to heavier or lighter values of $\delta^{13} \mathrm{C}$. Because photosynthetic fixation of carbon in the oceanatmosphere system preferentially incorporates ${ }^{12} \mathrm{C}$ into organic matter, the overall $\delta^{13} \mathrm{C}$ value of sea water at any one time primarily reflects the partitioning of the global carbon pool between oxidized (carbonate, bicarbonate, carbon dioxide) reservoirs and reduced (primarily organic carbon) reservoirs. Global increases in the amount of living biomass or the amount of carbon buried in the sedimentary record will affect the isotopic composition of dissolved inorganic carbon in the oceans so as to cause an increase in $\delta^{13} \mathrm{C}$ values; reduction in biomass, increase in oxidation of organic matter or any other flux of reduced carbon into the ocean-atmosphere system will cause the reverse. The stratigraphical association between a globally distributed record of carbon burial, registering an Oceanic Anoxic Event, and a positive carbon-isotope excursion is thus to be predicted (Scholle \& Arthur 1980).

Early studies on carbon-isotope stratigraphy were primarily undertaken on deep-sea carbonates cored from the oceans or collected at outcrop (e.g. Berger \& Vincent 1986). Subsequent work has utilized skeletal calcite and aragonite (Veizer et al. 1999). The fractionation factor between marine bicarbonate and calcite is small $(c .+1 \%)$, whereas for aragonite it is a little larger $(c .+2.7 \%)$ : these effects appear to be broadly indepen- dent of temperature and precipitation rate (Romanek et al. 1992). So-called 'vital effects', physiological processes such as respiration and the photosynthetic activity of symbionts, may also affect the ${ }^{13} \mathrm{C} /{ }^{12} \mathrm{C}$ ratio of a particular skeletal carbonate (e.g. Fig. 7). Furthermore, changes in the concentration of sea-water carbonate, perhaps dependent on shifts in the partial pressure of $\mathrm{CO}_{2}$, are also implicated in affecting $\delta^{13} \mathrm{C}$ ratios in carbonates (Spero et al. 1997). The influence of diagenesis also needs to be carefully evaluated in each case (Marshall 1992): this is particularly evident in the case of negative carbon-isotope excursions, which may either reflect a real change in ocean chemistry or represent diagenetic artefacts caused by the introduction of an isotopically light cement. Despite these potentially significant factors, useful chemostratigraphical signals are commonly preserved, even if original isotopic values are modified to some degree.

The isotope curve has its greatest potential as a high-resolution correlative tool at those stratigraphical levels where it is characterized by distinctive shape and form. Carbon-isotope studies in the Jurassic period have concentrated on bulk samples of pelagic facies of the Alpine-Mediterranean domain (rosso ammonitico and associated facies), but some studies on the Jurassic sequences of northern Europe have also been undertaken, both on bulk carbonate and skeletal calcite. Unfortunately, however, such common macrofossils as ammonites, belemnites and oysters commonly give relatively scattered data, even when carefully screened for diagenetic alteration (Fig. 7). General $\delta^{13} \mathrm{C}_{\text {carb }}$ trends for pelagic carbonates and belemnites through much of Jurassic time have been illustrated by Bartolini et al. (1996) and Podlaha et al. (1998), respectively. In the Lower Jurassic succession of the Basque Cantabrians, northern Spain, belemnite rostra give consistently heavier and presumably palaeoceanographically more reliable $\delta^{13} C_{\text {carb }}$ values than do brachiopods or the enclosing organic-rich hemipelagic carbonates (Rosales et al. 2001). The Jurassic $\delta^{13} \mathrm{C}$ values determined and compiled by Gruszczyński (1998), based on analyses of ammonites, belemnites, bivalves, echinoderms, foramifera, nautiloids and bulk rock, follow the same general trends as those illustrated in Figure 7.

Future work will involve additional carbon-isotope stratigraphy of lacustrine and pedogenic carbonates (calcretes) carbonate phases in oolitic goethite as well as fossil wood and other terrestrial organic matter from shallow-marine and fluvial deposits (e.g. Yapp \& Poths 1996; Ekart et al. 1999; Hesselbo et al. 2000a). Studies of Cretaceous and Tertiary examples have shown that correlation between the marine carbonate and continental record is possible when isotopic shifts characterize the whole of the ocean-atmosphere system (e.g. Koch et al. 1992; Hasegawa 1997; Gröcke et al. 1999).

In addition to carbonate samples, isotopic changes in the composition of organic matter, although applicable only to carbon-rich sequences, may also be of stratigraphical worth. Controls on the $\delta^{13} \mathrm{C}$ composition of preserved organic matter are considerably more complex than those on carbonate and include, in addition to the isotopic composition of dissolved inorganic carbon in sea water, one or more of the following: (1) a change in the relative proportionality of marine and terrestrial organic carbon; (2) a change in primary producers to organisms exhibiting different selectivity against ${ }^{13} \mathrm{C}$; (3) changes in the levels of $\mathrm{CO}_{2}$ in the ocean-atmosphere system; (4) post-burial bacterial reworking of the organic matter; (5) variations in the amount of ${ }^{13} \mathrm{C}$-enriched sulphur-bound carbohydrate carbon preserved in the organic matter (Jenkyns \& Clayton 1986, 1997; Hollander et al. 1991; Kenig et al. 1994; Sinninghe Damsté et 


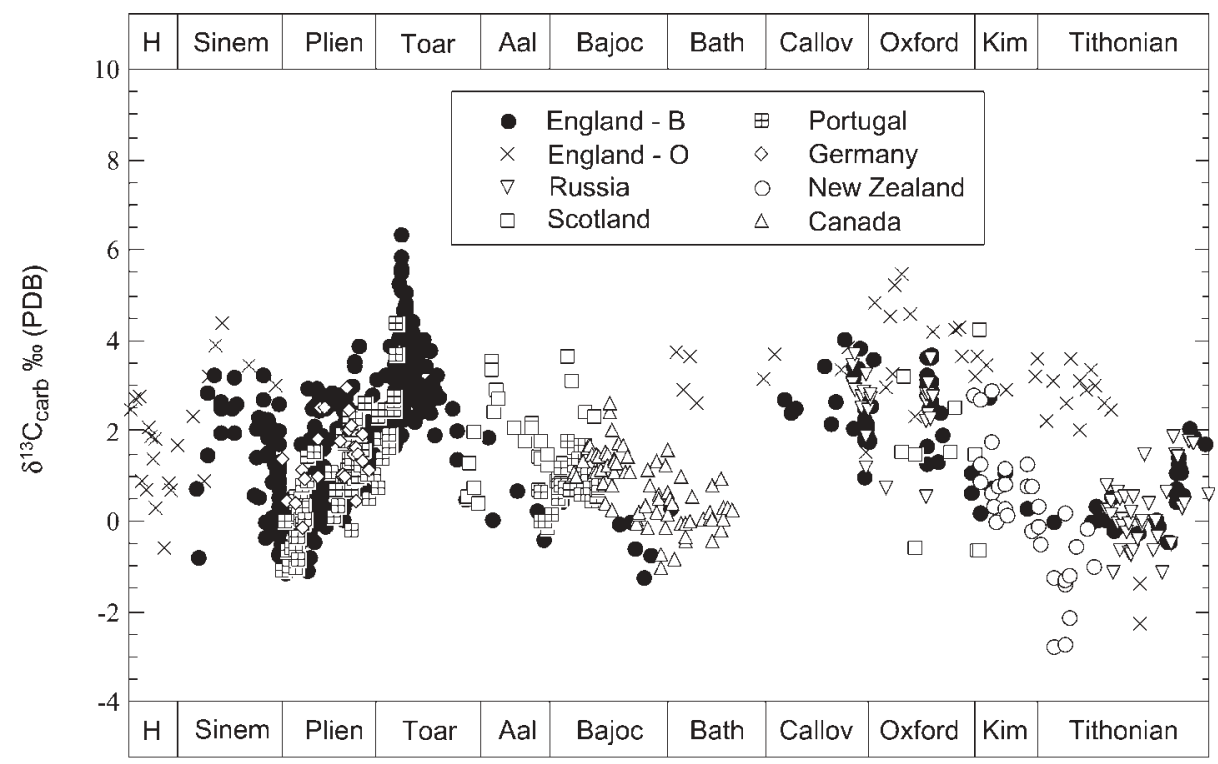

Fig. 7. Carbon-isotope plot for the Jurassic, based on diagenetically screened belemnites (Fe $<150 \mathrm{ppm}$ ) from England (England-B), Scotland, Germany, Portugal, Russia, New Zealand and non-screened oysters from England (England-O). The latter dataset, although not as reliable as the former, is necessary to provide detailed coverage of the Callovian-Tithonian interval. The trends are interpreted as global. Data from Jones et al. (1994b, 1994c), Parkinson (1994), Podlaha et al. (1998), McArthur et al. (2000a) and Gröcke (2001). Significant features are the negative $\delta^{13} \mathrm{C}$ excursion around the SinemurianPliensbachian boundary and the positive excursion in early Toarcian time, a feature that is reproducible in bulk carbonate across Europe. Relatively low values define the Bajocian-Bathonian boundary interval and the Tithonian interval. The relatively high values of $\delta^{13} \mathrm{C}$, characteristic of early Oxfordian time, derive from oysters whose carbon-isotope values generally plot above those of coeval belemnites, probably as a result of diagenesis or vital effects. Further work is necessary to determine whether apparent excursions are reproducible on a regional scale. Conflation of datasets from different faunal provinces, with different biostratigraphical schemes, will introduce some stratigraphical error. Duration of stages is plotted according to the number of subzone units.

al. 1998; Sælen et al. 2000). Also, in areas of vigorous upwelling, recycling of waters containing oxidized carbon may locally impart a more negative carbon-isotope signature than that typical of adjacent water masses, and such a signature could be transmitted to planktonic organic carbon and carbonate, as suggested for various Jurassic black shales (Küspert 1982; Hollander et al. 1991; Sælen et al. 1998). These complications may render the stratigraphical interpretation of the $\delta^{13} \mathrm{C}_{\text {org }}$ record more problematic than the $\delta^{13} C_{\text {carb }}$ record.

\section{Triassic-Jurassic boundary}

Until very recently, the carbon-isotope data for the TriassicJurassic boundary interval, from both marine carbonates (McRoberts et al. 1997) and organic matter (McElwain et al. 1999), were of relatively low resolution. When contrasting bulkcarbonate $\left(\delta^{13} \mathrm{C}_{\text {carb }}\right)$ and bulk marine organic-matter $\left(\delta^{13} \mathrm{C}_{\text {org }}\right)$ curves have been derived from the same section in Austria, both signals have been interpreted as of dubious stratigraphical significance (Morante \& Hallam 1996). New data from marine organic matter in NW Canada (Ward et al. 2001) and organic matter and carbonates from a marine section in Hungary (Pálfy et al. 2001) demonstrate the existence of a negative carbonisotope excursion close to the system boundary. The same excursion is recognized in bulk organic matter from SW England and in terrestrial organic matter from East Greenland (Hesselbo et al. 2002) and, in both sections, the excursion corresponds to a level of abrupt biotic turnover. The widespread recognition of the excursion in many different facies and geological materials leads to the suggestion that it may make a suitable marker for definition of the boundary. The origin of the negative excursion in this case may be attributed either to a global collapse of organic productivity (Ward et al. 2001) or to the emission of isotopically light $\left(\delta^{13} \mathrm{C} c\right.$. $\left.-7 \%\right)$ volcanogenic carbon dioxide coincident with massive extrusion of lavas of the Central Atlantic Magmatic Province (Hesselbo et al. 2002).

\section{Hettangian-Sinemurian-Pliensbachian interval}

The compilation of $\delta^{13} \mathrm{C}$ values of oysters and belemnites from England and Portugal (Fig. 7) shows a possible negative excursion in Hettangian time followed by a positive excursion centred in mid-Sinemurian time and subsequently by a well-defined negative excursion around the Sinemurian-Pliensbachian boundary. This latter excursion, defined by belemnite data only, is discernible in material from English, German and Portugese sections and has clear potential as a feature of chemostratigraphical use.

\section{Pliensbachian-Toarcian interval}

Pliensbachian carbon-isotope stratigraphy, based on studies of pelagic-carbonate sections in the Apennines of Italy, has been comprehensively investigated by Morettini (1998). Her data show a positive $\delta^{13} \mathrm{C}_{\text {carb }}$ step of $c .0 .5 \%$ from a background of $c$. $1.5 \%$ in the upper jamesoni Zone followed by a rise to a maximum in the upper ibex Zone of the Pliensbachian interval, where values reach a little more than $2.5 \%$ and then decay away into the davoei Zone. This ibex Zone relative maximum was also identified by Rosales et al. (2001) in belemnite rostra from the Basque-Cantabrian Basin of northern Spain. A carbon-isotope stratigraphy of the Pliensbachian-Toarcian boundary interval in Switzerland, Italy and Hungary was undertaken by Jenkyns \& Clayton (1986). They documented, from bulk pelagic limestones, 
a small positive $\delta^{13} \mathrm{C}_{\text {carb }}$ excursion (of $c .1 \%$ from a background of c. $2 \%$ ) in the subnodosus Subzone of the margaritatus Zone, and this event was also identified by Morettini (1998) in her study of additional Italian and Spanish sections.

A larger positive excursion (a shift of c. $2 \%$ from a background of $2-2.5 \%$ ) during the early falciferum Zone was identified by Jenkyns \& Clayton (1986). An extension of this work by Jenkyns et al. (1991) recorded the falciferum Zone positive $\delta^{13} \mathrm{C}$ excursion from additional sections in Hungary and Austria. Subsequent work on British sections by Jenkyns \& Clayton (1997) revealed this excursion in the lower falciferum Zone from bulk carbonate in the Junction Bed of Somerset and from coeval clay-rich limestones in the Winterborne Kingston Borehole in Dorset. This positive $\delta^{13} \mathrm{C}_{\text {carb }}$ excursion is localized in the uppermost part of the exaratum Subzone according to data from belemnite rostra in the Jet Rock of Yorkshire (McArthur et al. 2000a). This latter occurrence is important as it gives the most refined date for the positive $\delta^{13} \mathrm{C}$ excursion of early Toarcian time (Figs 2 and 5). Isotopic studies of the Mochras Borehole in Wales are also particularly instructive (Fig. 3) because they illustrate a broad positive excursion extending over the tenuicostatum and falciferum Zones, interrupted by an abrupt negative excursion centred in the exaratum Subzone. Again, this same $\delta^{13} \mathrm{C}$ trend is illustrated by high-resolution data from belemnites in the Hawsker Bottoms and other sections in Yorkshire (McArthur et al. 2000a). Essentially this pattern defines two positive excursions, one centred in the upper tenuicostatum Zone and another centred around the exaratum-falciferum Subzone boundary. In these sections the stratigraphically higher positive $\delta^{13} \mathrm{C}$ excursion immediately post-dates the TOC maximum.

The assignment of the early Toarcian positive $\delta^{13} \mathrm{C}$ excursion to the upper part of the serpentinus Zone in the Subbetic Zone of Spain by Jiménez et al. (1996) was taken by them to suggest that the shift was diachronous across the Tethyan region and related to poor mixing of water masses. However, this apparent mismatch is more plausibly related to difficulties in correlation, at the subzonal level, between the Spanish and other sections, particularly as there are apparently at least two positive excursions over the lower Toarcian interval, if the Mochras section is diagnostic. In the Italian sections from the Marche-Umbrian Apennines studied by Morettini (1998), the $\delta^{13} \mathrm{C}$ maximum was variously identified in the early, mid- and late serpentinus Zone, probably reflecting marked local differences in the rate of sedimentation and erosion during this interval. Maximum $\delta^{13} \mathrm{C}$ values in belemnites from the Jet Rock of Yorkshire straddle the exaratum-falciferum Subzone boundary, which probably lies close to the middle part of the serpentinus Zone in the Spanish and Italian sections (Fig. 5). In the Basque-Cantabrian Basin belemnites give a maximum $\delta^{13} \mathrm{C}$ value of $4.3 \%$ in the lower serpentinus Zone (Rosales et al. 2001).

In the Lusitanian Basin of Portugal, the negative $\delta^{13} \mathrm{C}$ excursion, documented from stratigraphically expanded hemipelagic limestones and marls, characterizes the boundary between the semicelatum and the serpentinus Zones, and the subsequent positive excursion is centred in the middle part of the serpentinus Zone (Duarte 1998). In Portugal, the base of the serpentinus Zone is defined not by the first appearance of Hildaites but by the first appearance of Harpoceratoides (Elmi et al. 1989) and the zone is not exactly equivalent to that in the Subbetic ranges of Spain or in Italy. The isotope stratigraphy shows clearly, however, that the negative $\delta^{13} \mathrm{C}$ excursion must be assigned to the lower exaratum Subzone in terms of British stratigraphical nomenclature (Fig. 5).

The $\delta^{13} \mathrm{C}_{\text {org }}$ signatures through part of the lower Toarcian sequence are also established from the work of Küspert (1982, 1983), Jenkyns \& Clayton (1986, 1997), Hollander et al. (1991), Hesselbo et al. (2000a), Jenkyns et al. (2001) and Röhl et al. (2001). Küspert $(1982,1983)$ demonstrated the presence of a broad negative excursion in $\delta^{13} \mathrm{C}_{\mathrm{org}}$ values (from about -28 to $-32 \%$ ) centred in the lower exaratum Subzone in sections from Yorkshire and southern France (Mende). A negative excursion in organic carbon, of similar magnitude and absolute values, was documented by Hollander et al. (1991) from a core through the Schistes Carton(s) of the Paris Basin, but there is no fine-scale biostratigraphy against which this event can be calibrated. Jenkyns Jenkyns \& Clayton (1997), Hesselbo et al. (2000a) and Jenkyns et al. (2001) documented the same negative excursion in $\delta^{13} \mathrm{C}_{\mathrm{org}}$ through the Jet Rock as did Küspert $(1982,1983)$, but with more data points, and demonstrated that the negative shift began abruptly towards the close of the tenuicostatum Zone with lowest values attained in the early exaratum Subzone. Those workers also found a similarly structured negative excursion, in both $\delta^{13} \mathrm{C}_{\text {org }}$ and $\delta^{13} \mathrm{C}_{\text {carb }}$, in organic-rich shales from the Mochras Borehole. In both the Yorkshire (Jet Rock) and Mochras sections, the more negative $\delta^{13} \mathrm{C}_{\text {org }}$ values generally correlate with the most carbonrich part of the sequence (Figs 2 and 3). Similar chemostratigraphical patterns were found in the Posidonienschiefer of Germany by Küspert $(1982,1983)$ and Röhl et al. (2001). Van Kaam-Peters (1997) and Schouten et al. (2000) demonstrated that the negative excursion in the Posidonienschiefer was of similar magnitude in a range of organic geochemical biomarkers and hence probably reflected the carbon-isotope composition of near-surface waters.

Carbon-isotope stratigraphy through Toarcian organic-rich sections from the Southern Alps of Italy (Lombardian Basin) and the Italian Apennines, described by Jenkyns \& Clayton (1986) and Morettini \& Bartolini (1999), respectively, also contain a negative excursion, of c. $3 \%$, in $\delta^{13} \mathrm{C}_{\text {carb. }}$. On the basis of available ammonite stratigraphy, this excursion can be taken to correlate in time with the same event in northern Europe. A similar negative excursion in $\delta^{13} \mathrm{C}_{\text {carb }}$, correlative with a maximum in TOC, was also recorded by Bellanca et al. (1999) from a sequence of Toarcian black shales and manganoan carbonates, of probable falciferum Zone age, cropping out elsewhere in the Southern Alps (Belluno Basin, Italy; Jenkyns et al. 1985). These sediments, reanalysed by Jenkyns et al. (2001), show an abrupt negative carbon-isotope excursion in both carbonate and organic carbon, and the isotopic profile is essentially identical to that from Yorkshire, allowing application of a notional north European ammonite biostratigraphy to the Italian section.

Looking at the Toarcian interval as a whole across Europe, a negative $\delta^{13} \mathrm{C}$ excursion in organic matter and, locally, in carbonates characterizes the lower exaratum Subzone, and this level is relatively organic-carbon-rich with respect to sub- and suprajacent strata. Further, a positive $\delta^{13} \mathrm{C}$ excursion in organic matter locally (Mochras Borehole) characterizes the tenuicostatum Zone, and a positive $\delta^{13} \mathrm{C}$ excursion in organic matter, bulk carbonate and belemnite rostra characterizes the upper exaratum Subzone and is apparently traceable across northern and southern Europe (Fig. 5). Application of these chemostratigraphical indices to the section cored in the Winterborne Kingston Borehole indicates the definitive presence of the exaratum Subzone, even though it has not been proved palaeontologically (Jenkyns \& Clayton 1997).

The same principles have also been applied to shallow-water platform carbonates of the Southern Alps of Italy (Woodfine et al. 2001). Recognition of a characteristic negative followed by a positive $\delta^{13} \mathrm{C}_{\text {carb }}$ excursion has allowed definition of the falciferum Zone in a sequence generally devoid of stratigraphically useful 
biota. In this instance the impact of the early Toarcian Oceanic Anoxic Event is illustrated by the development of a more clayrich and sponge-rich cherty facies over the interval in question.

The $\delta^{13} \mathrm{C}_{\text {org }}$ values of Toarcian organic matter that define the negative excursion, commonly in the range of -29 to $-34 \%$ wherever they have been analysed in Europe, are unusual enough amongst Jurassic black shales to offer a potential correlative tool, even if sampling is too incomplete to illustrate the complete isotopic profile (Jenkyns 1988). $\delta^{13} \mathrm{C}_{\text {org }}$ values of around $-30 \%$ in certain levels of Toarcian black shales are recorded, in northern Europe, from England, France and northern Germany (Küspert 1982, 1983; Hollander et al. 1991; Jenkyns \& Clayton 1997) and, in Tethyan Europe, from Austria-southern Germany, Greece (Ionian Zone and Pindos Zone: Kastelli Pelites and correlatives; Jenkyns 1988 and unpublished data), the Bakony Mountains of Hungary and the Marche-Umbrian Apennines and Southern Alps of Italy (Jenkyns \& Clayton 1986, 1997; Vetö et al. 1997; Ebli et al. 1998; Morettini 1998). Whether or not all these low $\delta^{13} \mathrm{C}_{\text {org }}$ values are unique to the lower exaratum Subzone, in terms of British stratigraphical usage, must in part relate to whether the controlling factors behind these particular carbon-isotope compositions are regional or local (see Jenkyns \& Clayton 1986, 1997; van Kaam-Peters 1997; Sælen et al. 1998; Hesselbo et al. 2000a; Schouten et al. 2000). Assignment to the exaratum Subzone is, however, established for the north European examples. In Winterborne Kingston, $\delta^{13} \mathrm{C}_{\text {org }}$ values of between -31 and $-30 \%$ have been determined from the organic-rich part of the Lower Toarcian section (Jenkyns et al. 2001), further reinforcing the evidence for the presence of the (lower) exaratum Subzone.

Organic-rich shales of probable Toarcian age from the Arctic Slope of Alaska yield $\delta^{13} C_{\text {org }}$ values of between -33 and $-31 \%$ (Kingak Shales; Magoon \& Claypool 1984). Such low values are thus not solely a European phenomenon.

With regard to local versus regional controls on these characteristic $\delta^{13} \mathrm{C}_{\text {org }}$ values, the recent work by Hesselbo et al. $(2000 a)$ on carbon-isotope signatures of terrestrial wood fragments from the marginal marine Toarcian sequence of Bornholm, Denmark, is particularly significant in that it has revealed the same negative excursion as seen in marine organic matter, albeit with higher absolute values. These data suggest that the whole of the exchangeable carbon reservoir in the ocean-atmosphere system underwent a change in isotopic composition, which rules out the influence of local oceanographical effects. Specifically, Hesselbo et al. (2000a) suggested that dissociation of gas hydrates $\left(\delta^{13} \mathrm{C}_{\text {methane }}\right.$ c. $\left.-60 \%\right)$ in continental-margin sediments during a period of relative global warmth, realignment of bottom currents and/or regional extensional tectonics led to the observed isotopic response, which must necessarily have been a global phenomenon. After this abrupt and apparently rapid negative $\delta^{13} \mathrm{C}$ shift, there was a more gradual return to more positive values because of a steady transfer of excess organic carbon into the burial environment as was the case before the putative release of methane from gas hydrates.

Sections through Tethyan pelagic limestones and British shelf carbonates from Mochras (Fig. 3) and Winterborne Kingston show a small positive $\delta^{13} \mathrm{C}_{\text {carb }}$ excursion of $c .1 \%$ in the bifrons Zone (Jenkyns \& Clayton 1986, 1997). This excursion may prove to be a stratigraphically reproducible feature.

\section{Aalenian-Bajocian interval}

The work of Bartolini et al. (1996, 1999) demonstrated the presence of a small positive carbon-isotope excursion, from about 2.5 to $3.5 \%$ in $\delta^{13} \mathrm{C}_{\text {carb }}$, in the middle part of early Bajocian time in a pelagic-carbonate section in the MarcheUmbrian Apennines. More precise dating of this event, by Corbin (1994) through a well-dated section in the Digne area of southern France and by Bartolini \& Cecca (1999) from another section in March-Umbria, showed that $\delta^{13} \mathrm{C}$ values increase during the laeviscula Zone to peak in the sauzei Zone; after a decline in the lower humphriesianum Zone values rise again in the higher part of that Zone. This positive excursion has also been identified from a sequence of redeposited radial calcitic oolites in the Belluno Trough, Southern Alps, Italy (Zempolich \& Erba 1999). More work is needed to define this excursion in other well-dated sections. In the Italian section there is a stratigraphical association of the positive excursion with more chert-rich lithologies, suggestive of increases in radiolarian abundance and more nutrient-rich waters at this time (Bartolini et al. 1999).

New data from belemnites from the Bearreraig section in the Isle of Skye also show a sharp $\delta^{13} \mathrm{C}$ peak in the murchisonae Zone (Aalenian time) and a broad $\delta^{13} \mathrm{C}$ maximum in the laeviuscula, sauzei and humphriesianum Zones (Fig. 8). In both cases values rise from a background of $1-1.5 \%$ to $c$. $3.5 \%$. The stratigraphically higher excursion in the Scottish section clearly has regional significance. Probable negative excursions are present close to the limit of Toarcian and Aalenian time and around the discites-ovalis zonal boundary.

\section{Callovian-Oxfordian interval}

A number of sections through the Callovian-Oxfordian sequence in France, Italy and Switzerland have shown the presence of several small-scale $\delta^{13} \mathrm{C}$ excursions registered in pelagic carbonate (Bartolini et al. 1996, 1999; Jenkyns 1996; Weissert \& Mohr 1996; Cecca et al. 2001). Jenkyns (1996) and Cecca et al. (2001) recorded a single peak within the lower-middle Callovian sequence of, respectively, the Southern Alps of north Italy and western Sicily, but the sections are extremely condensed. Bartolini et al. $(1996,1999)$ tentatively recognized a double $\delta^{13} \mathrm{C}$ peak within the Callovian sequence of a more expanded but less well-dated section in the Italian Apennines. This they suggested may correlate with the two excursions in $\delta^{13} \mathrm{C}_{\mathrm{org}}$, in the calloviense and lower jason Subzones, respectively, illustrated by Kenig et al. (1994) from the Kellaways Formation and the Oxford Clay of central England. As noted above, this latter horizon is characterized by a TOC maximum. Carbon-isotope data from macrofossils (ammonites, belemnites, bivalves) through the Oxford Clay are relatively scattered and do not evince obvious trends, although relatively high values $\left(\delta^{13} \mathrm{C} c\right.$. $5 \%$ ) are recorded from bivalves in the lower jason Subzone (Anderson et al. 1994). Although Kenig et al. (1994) specifically excluded secular changes in the carbon-isotope composition of the dissolved inorganic carbon pool as an explanation for the positive shifts of $\delta^{13} \mathrm{C}_{\text {org }}$, in the Oxford Clay, the regional extent of a mid- to early Callovian positive $\delta^{13} \mathrm{C}_{\text {carb }}$ excursion/s shows that this explanation needs to be reconsidered.

Jenkyns (1996) documented a distinct $\delta^{13} \mathrm{C}$ excursion (from about 2.5 to $3.5 \%$ ) in the tranversarium Zone (partly correlative with the glosense Zone; Fig. 1) of sections from Italy and southern France, and this excursion, although not resolved to zonal level, is almost certainly shown in the Italian data of Bartolini et al. (1996). Weissert \& Mohr (1996) also illustrated this excursion in strata from eastern Switzerland, and Bill et al. (1995) recorded it in crinoid and echinoid skeletal material from sequences of tranversarium Zone age in the Swiss Jura, although the details of the zonal stratigraphy are not unambiguous 


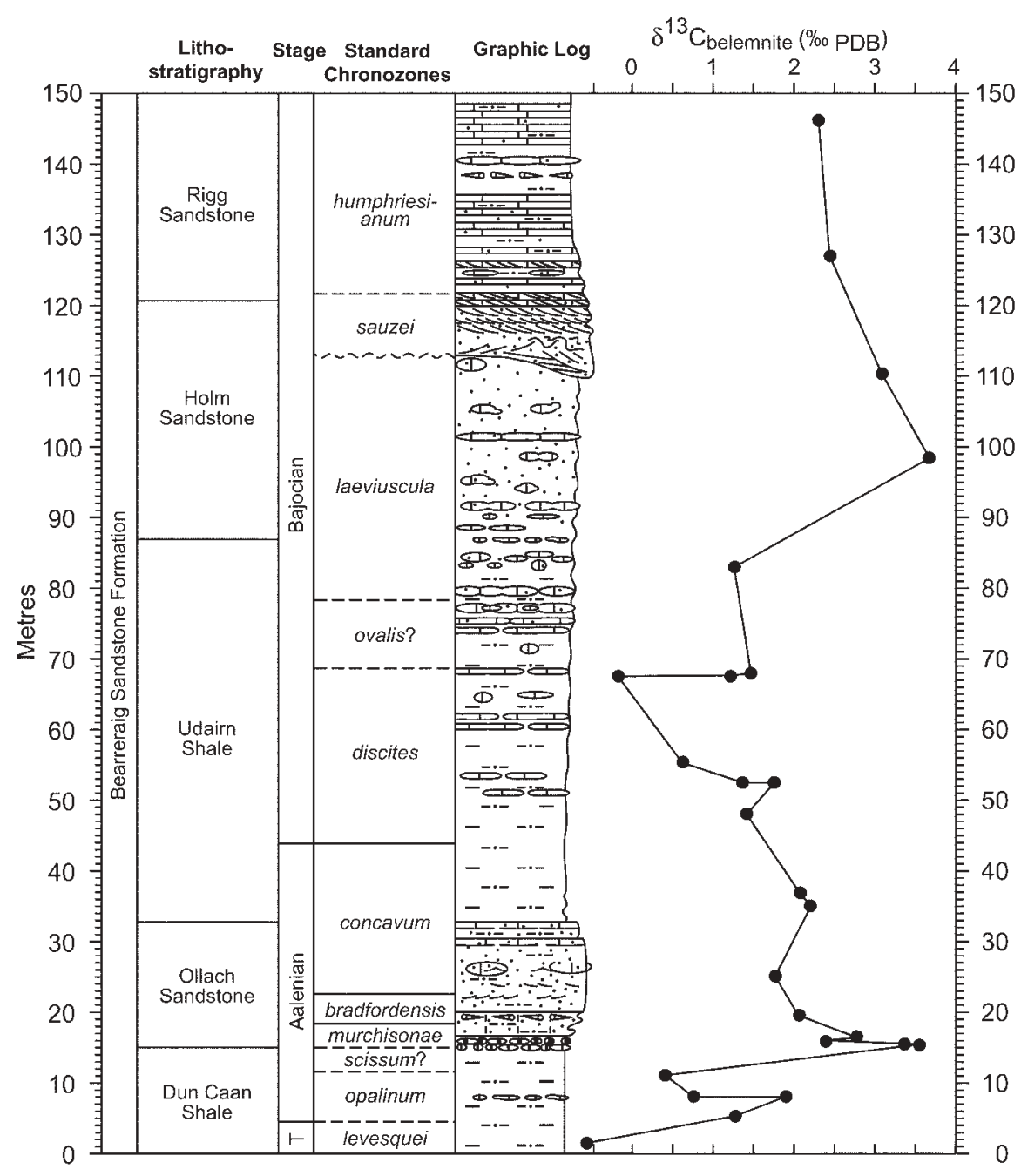

Fig. 8. Lithological section through the Bearreraig Sandstone, Trotternish, Isle of Skye, Scotland, showing carbon-isotope data from diagenetically screened belemnites ( $\mathrm{Fe}<150 \mathrm{ppm})$. The positive $\delta^{13} \mathrm{C}$ excursions should be noted in the murchisonae and laeviuscula Zones, the latter correlating with patterns seen elsewhere in Europe. Isotopic data in Gröcke (2001); biostratigraphy after Morton \& Hudson (1995). Lithological symbols as in Fig. 2.
(Jenkyns 1996). A subdued peak in $\delta^{13} \mathrm{C}$ values (rising from a background of c. $3 \%$ to a maximum of c. $4 \%$ ), based on brachiopod shell material, is also recognized in the tranversarium Zone of central Poland (Hoffman et al. 1991). Belemnites from the same area show a broadly similar trend, although their $\delta^{13} \mathrm{C}$ values are some $2.5-3 \%$ lower than those of coeval brachiopods, perhaps as a result of different 'vital effects' in either or both of these organisms (Wierzbowski 2002). The positive excursion correlates with the onset of deposition of organic-rich shales in a number of localities around the world (Jenkyns 1996); in Italian sections there is an association with more chert-rich lithologies, suggestive of increases in radiolarian abundance and more nutrient-rich waters during this interval (Bartolini et al. 1999). Brachiopod-based curves from Poland and southern Germany show a $\delta^{13} \mathrm{C}$ maximum in the bimmmamatum (equivalent to rosenkrantzi) Zone (Pisera et al. 1992).

Values of $\delta^{13} \mathrm{C}$ in excess of $5 \%$ are determined from upper Callovian-mid-Oxfordian oysters from Britain (Fig. 7), and relatively high values are also recorded from coeval belemnites from Russia (Podlaha et al. 1998; Barskov \& Kiyashko 2000). Very high-resolution studies of bulk carbonate across the tranversarium Zone from sections in the Jura Mountains and Helvetic Alps of Switzerland and the Vocontian Basin of SE France $\left(\delta^{13} \mathrm{C}_{\text {carb }}\right.$ and $\left.\delta^{13} \mathrm{C}_{\text {org }}\right)$ show a pronounced negative excursion of $1-3 \%$, locally followed by a positive excursion in $\delta^{13} \mathrm{C}_{\text {carb }}$ to $3 \%$ then a decay to background values of c. 2\%o (Padden 2001;
Padden et al. 2001). As with the negative excursion in the exaratum Subzone of the Toarcian interval, this similar isotopic shift has been explained as due to dissociation of gas hydrates from continental-margin sediments (see Hesselbo et al. 2000a). The belemnite data from this interval (Fig. 7) are too scattered to indicate distinct trends.

\section{Kimmeridgian-Tithonian interval}

The $\delta^{13} \mathrm{C}_{\text {org }}$ record through the type Kimmeridge Clay of Dorset (Morgans-Bell et al. 2001; Fig. 6) indicates a declining trend from the cymodoce to the mid-eudoxus Zone, followed by a step up from average values of c. $-28 \%$ to $c$. $-25 \%$ and a subsequent peak at $c$. $-23 \%$ (the mid-eudoxus positive shift). There is also a fundamental change in the nature of the isotopic curve at this level: below, $\delta^{13} \mathrm{C}_{\text {org }}$ values show variability typically in the range of $1-2 \%$ and the curve is coherent and well defined; above, values are much more variable and the curve more 'spiky'. A notable feature is the difference in correlation between values of total organic carbon and $\delta^{13} \mathrm{C}_{\text {org }}$ in these two parts of the section. From the baylei Zone to the mid-eudoxus Zone the correlation is broadly negative. The reverse (i.e. positive) relationship is apparent above the mid-eudoxus Zone, a phenomenon also observed, albeit with smaller datasets, by Huc et al. (1992), Van Kaam-Peters et al. (1998) and Sælen et al. (2000) and variously interpreted. 
From the mid-eudoxus interval upwards, $\delta^{13} \mathrm{C}_{\text {org }}$ values increase somewhat, as do the TOC values. Sections of organic-rich sediment with relatively high $\delta{ }^{13} \mathrm{C}_{\mathrm{org}}$ values are present in the stratigraphical vicinity of the Nannocardioceras Beds (eudoxus Zone: $\delta^{13} \mathrm{C}_{\text {org }}$ values rising to $c$. $-22.5 \%$ from a background of c. $-26 \%$ ), the Blackstone Band (top of wheatleyensis Zone, base of hudlestoni Zone: $\delta^{13} \mathrm{C}_{\text {org }}$ values rising to $c$. $-23 \%$ from a background of $c$. $-27 \%$ ), and a more well-defined peak of similar magnitude and similar absolute values is located around the White Stone Band (top of hudlestoni Zone, base of pectinatus Zone). A number of other peaks of similar relative magnitude and absolute values are present in the upper autissiodorensis, elegans and scitulus Zones. The overall trend, however, upwards from the elegans Zone is towards lower carbon-isotope values.

The mid-eudoxus positive shift is also registered in the $\delta^{13} \mathrm{C}_{\mathrm{carb}}$ values of pelagic-hemipelagic carbonates from the Helvetic Nappes of eastern Switzerland, northern Tethys (Weissert \& Mohr 1996; Padden 2001), and is clearly a regional event of potential use for correlation. Because of the widespread nature of this event, it cannot be interpreted as related to local oceanographical conditions, such as increases in productivity in the water masses in and around the Late Jurassic Wessex Basin, or to stratigraphical changes in the relative abundance of different components in the organic matter. This positive shift must reflect the overall isotopic composition of dissolved inorganic carbon in European (?global) Kimmeridgian sea water. Consequently, it is most simply interpreted as the isotopic response to increases in organic-carbon burial in north European and possibly other Kimmeridgian-Tithonian basins, beginning in the mid-eudoxus Zone as clearly reflected in the organic carbon profile (Fig. 6). This interpretation could equally explain the positive relationship between TOC and $\delta^{13} \mathrm{C}_{\text {org }}$ above the mid-eudoxus Zone.

However, whether or not the other excursions similarly reflect the overall isotopic composition of dissolved inorganic carbon in Kimmeridgian-Tithonian sea water, or whether they relate to high producivity of phytoplankton and consequent local enrichment of a near-surface water mass in $\delta^{13} \mathrm{C}$, or indeed either of these palaeoceanographical effects, is not established, although the former interpretation has the virtue of simplicity. Sælen et al. (2000) favoured productivity variations of the phytoplankon, accompanied by a change between calcareous and organic-walled species, as a first-order control on both $\delta^{13} \mathrm{C}_{\text {org }}$ and TOC. Van Kaam-Peters et al. (1998) noted that individual biomarkers show smaller changes in their $\delta^{13} \mathrm{C}$ values than does $\delta^{13} \mathrm{C}_{\mathrm{org}}$, indicating a change in the nature of the preserved organic matter through the section; they attributed the relatively high $\delta^{13} \mathrm{C}$ values of the Blackstone and similar lithologies to the presence of enhanced quantities of isotopically heavy sulphurized carbohydrates.

Additional carbon-isotope stratigraphy through coeval carbonate sequences will establish the regional significance or otherwise of these post-mid-eudoxus Kimmeridgian-Tithonian chemostratigraphical trends in carbon-isotope values. In this regard, extant $\delta^{13} \mathrm{C}_{\text {carb }}$ data from Kimmeridgian-Tithonian pelagic to hemipelagic carbonates from the Swiss Alps, Southern Alps (Italy), western Sicily and neighbouring regions do not compare well with the $\delta^{13} \mathrm{C}_{\text {org }}$ record from the Kimmeridge Clay. The Tethyan signal shows a steady monotonic decline in $\delta^{13} \mathrm{C}_{\text {carb }}$ values, from c. $2-$ 2.5 to $1.5 \%$, during Tithonian time (Weissert \& Channell 1989; Cecca et al. 2001; Padden 2001). These discrepancies may indicate increasing lack of exchange between waters of the north European Kimmeridge Clay basin and the seaways and oceans to the south and west as well as stratigraphical changes in the nature of the Kimmeridgian-Tithonian organic matter. The $\delta^{13} \mathrm{C}_{\text {carb }}$ curve from Cuba (Gruszczyński 1998) more closely follows the aforemen- tioned Tethyan isotope trend, particularly with respect to a positive shift of variable magnitude close to the Kimmeridgian-Tithanian boundary, than that of it Kimmeridge Clay of Dorset. However, the Cuban record is too low resolution for accurate comparison.

British belemnites typically give $\delta^{13} \mathrm{C}$ values of $0-1 \%$ in the two preceding stages but values increase at the end of Jurassic time. Kimmeridgian-Tithonian belemnites from New Zealand plot on a similar trend (Fig. 7).

\section{Nitrogen isotopes}

Nitrogen-isotope $\left(\delta^{15} \mathrm{~N}\right)$ ratios can be determined from organic matter and may have a potential role in the chemostratigraphy of black shales. Stratigraphical variation through time has been demonstrated for the falciferum Zone of the Toarcian interval by Jenkyns et al. (2001), who documented a positive excursion in the lower exaratum Subzone, approximately coincident with the negative excursion in $\delta^{13} \mathrm{C}_{\mathrm{org}}$ and maximum values of TOC. This excursion, illustrated by the British sections from Hawsker Bottoms, and the Mochras and Winterborne Kingston Boreholes, rises from background $\delta^{15} \mathrm{~N}$ values of $c$. $-1.5 \%$ to peak at around $1.5-2 \%$, then decay to $c$. $-1.5 \%$ (Fig. 9). Similar $\delta^{15} \mathrm{~N}$ trends are present in a Toarcian Tethyan black-shale section from the Belluno Basin, Southern Alps, Italy (Jenkyns et al. 2001)

Interpretation of these trends may be made with reference to studies of Recent and sub-Recent sediments demonstrating that nitrogen-isotope values are water mass dependent (e.g. Altabet \& Francois 1994; Altabet et al. 1995; Holmes et al. 1997; Pride et al. 1999). The key chemostratigraphical association is that of the higher $\delta^{15} \mathrm{~N}$ values with the higher values of TOC in the falciferum Zone. Although increasing values of TOC are typically viewed as reflecting relatively enhanced productivity, dilution by other sedimentary components may change through time, as may the degree of preservation of the organic matter. However, given the regional distribution of these Toarcian black shales, an increase in productivity, at least or organic-walled plankton and possibly bacteria, seems likely. Quaternary-Recent sediments showing a positive relationship between TOC and $\delta^{15} \mathrm{~N}$ are known from a number of upwelling areas where organic productivity is high and the underlying water masses are oxygen depleted (Ganeshram et al. 2000). In these areas denitrification takes place, a process involving the oxidation of falling planktonic organic matter by dissolved nitrate and its reduction to elemental dinitrogen. Preferential uptake of the lighter isotope ${ }^{14} \mathrm{~N}$ during this reaction leads to water mass enrichment in ${ }^{15} \mathrm{~N}$, and upwelling relays this chemical signature in the remaining dissolved nitrate to the photic zone where the nutrient can be utilized by the planktonic and bacterial population and subsequently transmitted into the sedimentary record. Such a process is inferred to have taken place during early exaratum Subzone time across much of Europe during the early Toarcian Oceanic Anoxic Event (Jenkyns et al. 2001).

Given that the nitrogen-isotope signatures are water mass dependent, their use in high-resolution stratigraphical correlation is likely to be local rather than regional. In the case of the Toarcian interval, the $\delta^{15} \mathrm{~N}$ maximum does not exactly correlate with the TOC maximum in the exaratum Subzone in the sections examined to date, and the relatively elevated organic carbon values are deemed the more reliable stratigraphical index.

\section{Oxygen isotopes}

Oxygen-isotope stratigraphy of Paleogene to Recent deep-sea carbonates and their constituent calcareous nanno- and micro- 

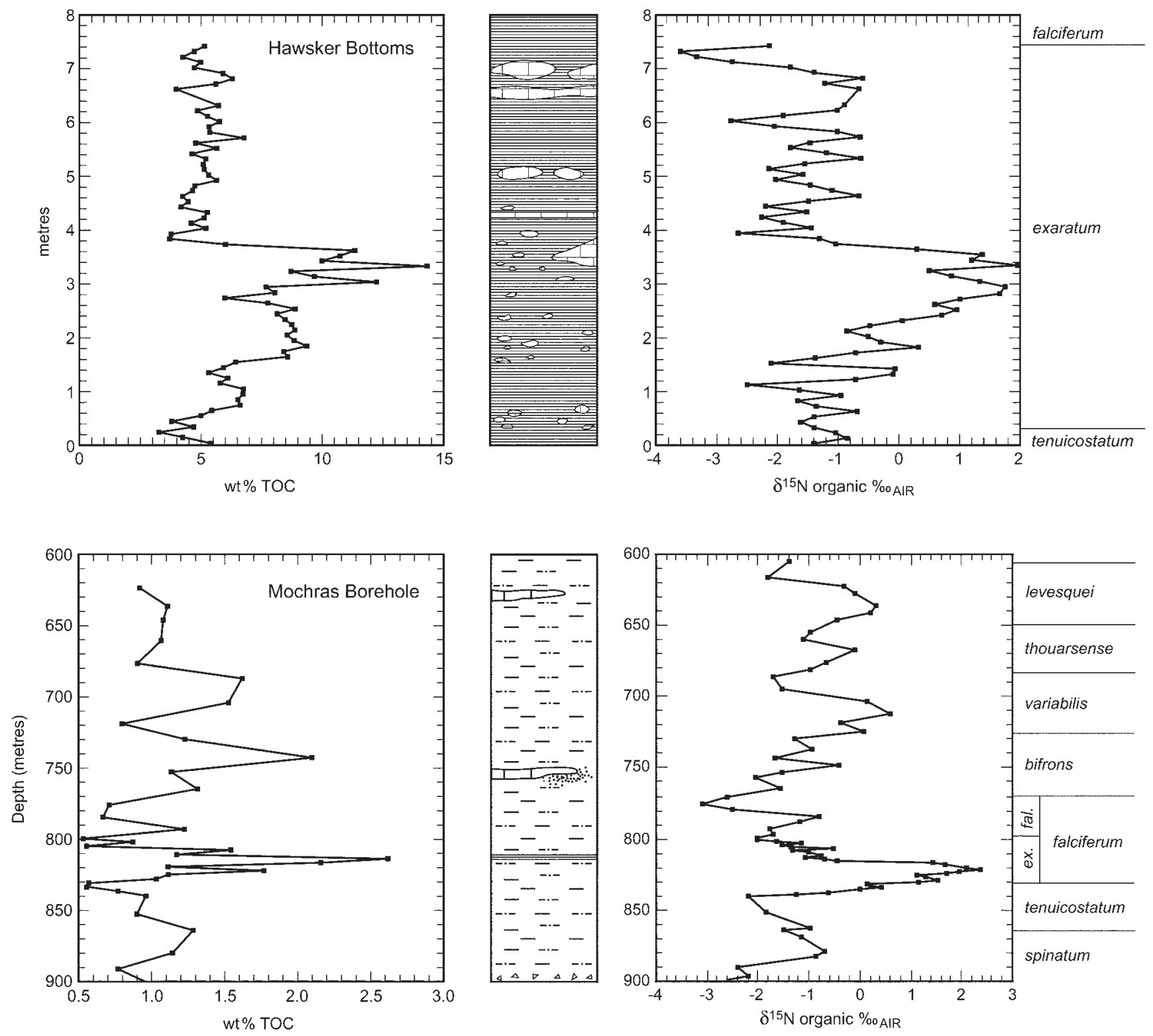

Fig. 9. Nitrogen-isotope curve for the lower Toarcian sequence (Jet Rock), Hawsker Bottoms, near Robin Hood's Bay, Yorkshire, England and the Mochras Borehole, Gwynedd, Wales. The general correlation with wt $\%$ TOC should be noted. Such a correlation probably reflects an increase in productivity of organic-walled plankton related to denitrification and upwelling of an oxygen-depleted subsurface water mass. Subsequent transmission of the isotopic signature into the sediment must then have taken place. Similar nitrogen-isotope profiles are recorded from other sections in England and Italy (Jenkyns et al. 2001). Lithological symbols as in Fig. 2.

fossils is well developed because of the presence of clearly defined and reproducible signals. Such signals primarily reflect the oxygen-isotope composition of the sea water from which the skeletal material was secreted. During Neogene time, particularly, $\delta^{18} \mathrm{O}$ values of sea water were greatly influenced by Antarctic ice volume, whereas for Mesozoic time, usually viewed as predominantly warm and equable, this factor is generally ignored (Hudson \& Anderson 1989; Zachos et al. 1994). Additional controls on the $\delta^{18} \mathrm{O}$ values of carbonates relate to the evaporation-precipitation balance in sea water and palaeotemperature, both potentially dependent on latitude and climate patterns. Furthermore, with older material, particularly if exposed on land, diagenesis is a potentially severe problem because of the interchange between interstitial waters and carbonates. Introduction of meteoric water will cause major isotopic readjustment of carbonate phases, as will recrystallization at progressively higher temperatures in the burial-diagenetic environment (Marshall 1992). Unlike carbon, the ratio of oxygen in pore waters to oxygen in calcareous sediment is relatively high (Scholle \& Arthur 1980).

Most work on oxygen isotopes in Jurassic and older deposits has concentrated on skeletal material (e.g. Veizer et al. 1999), although long time-series derived from bulk pelagic carbonates may in the future yield meaningful trends, as they do with Cretaceous samples (Hudson \& Anderson 1989; Jenkyns et al. 1994; Clarke \& Jenkyns 1999). A considerable body of literature on oxygen-isotope values of Jurassic belemnites was generated in the 1960 s and 1970 s by workers in the former Soviet Union (e.g. Berlin et al. 1967; Naydin \& Teys 1976) and in Europe (e.g. Fritz 1965), although the density of coverage and level of 
stratigraphical control was not particularly high and the question of vital effects, possible migration of the animals through the water column and diagenetic alteration largely unresolved (Spaeth et al. 1971; Veizer 1974; Veizer \& Fritz 1976). However, as shown by the exhaustive and painstaking study of Stevens \& Clayton (1971), $\delta^{18} \mathrm{O}$ values of belemnites show considerable scatter even if the fossils derive from the same stratigraphical horizon and lack evidence for diagenetic alternation, so that detailed chemostratigraphical correlation is impossible. More recent studies have only reinforced this conclusion (Anderson et al. 1994).

None the less, reproducible long-term trends in $\delta^{18} \mathrm{O}$ may be discernible. A recent compilation of oxygen-isotope ratios in belemnites through the whole of the Jurassic sequence, largely derived from Jones (1992), was given by Podlaha et al. (1998), and a slightly different dataset drawn from areas of similar palaeolatitude, presumably reflecting similar palaeotemperatures at any one time, is illustrated in Fig. 10 (Gröcke 2001). The isotopic determinations of oysters and belemnites, primarily from northern Europe, illustrates a rise in $\delta^{18} \mathrm{O}$ values from the basal Sinemurian (c. $-1 \%$ ) to peak in Aalenian-Bajocian time (c. $1 \%$ ) then decline from the Callovian-Oxfordian boundary into Tithonian time (c. $-2 \%$ ). Comparable values for Kimmeridgian-Tithonian time are known from southern Europe (Mallorca, Balearic Islands; Price \& Sellwood 1994). The Hettangian and lower Toarcian units buck the trend, however, by evincing sharp negative excursions to lower values. An excursion to higher oxygen-isotope values is characteristic of the Callovian-Oxfordian boundary, particularly evident in data from Russia (Riboulleau et al. 1998; Barskov \& Kiyashko 2000) and parts of Poland (Gruszczyński 1998). These patterns, if they prove to be globally reproducible, may be interpreted in terms of palaeotemperature change (highest palaeotemperature is indicated by low- est values of $\delta^{18} \mathrm{O}$ ) with relatively high temperatures in Hettangian and early Toarcian time and lowest temperatures in mid- to late Jurassic time. Palynological data from the southern North Sea region support the interpretation of relatively low palaeotemperatures around the Callovian-Oxfordian boundary (Abbink et al. 2001).

However, given that the Hettangian results derive from oysters, and these may register different vital effects and diagenetic imprints from belemnites, the palaeotemperature optimum in early Toarcian time (mid-exaratum Subzone from $\delta^{18} \mathrm{O}$ values in belemnites from Yorkshire) is deemed the more secure, particularly as it is supported by the maximum in $\mathrm{Mg} / \mathrm{Ca}$ ratios in belemnites of this age (McArthur et al. 2000a). Toarcian belemnites of early serpentinus Zone age from the Basque-Cantabrian Basin give minimum $\delta^{18} \mathrm{O}$ values when compared with Pliensbachian counterparts (Rosales et al. 2001), indicating that these isotopic signals are regionally reproducible. Further support for the interpretation that these broad $\delta^{18} \mathrm{O}$ trends largely reflect Jurassic palaeotemperature comes from the good correspondence to climatic trends, Callovian-Oxfordian boundary 'cold snap' excepted, adduced from the abundance of warmth-loving Classopollis pollen in the former Soviet Union (Vakhrameyev 1982).

\section{Sulphur isotopes}

The sulphur-isotope composition of sea water predominantly reflects the partitioning of sulphur between oxidized (sulphate) reservoirs and reduced (predominantly sulphide) reservoirs. Bacterial suphate reduction involves preferential incorporation of the lighter isotope ${ }^{32} \mathrm{~S}$ relative to ${ }^{34} \mathrm{~S}$; hence an increase in rates of sulphide formation would produce higher $\delta^{34} \mathrm{~S}$ values in sea

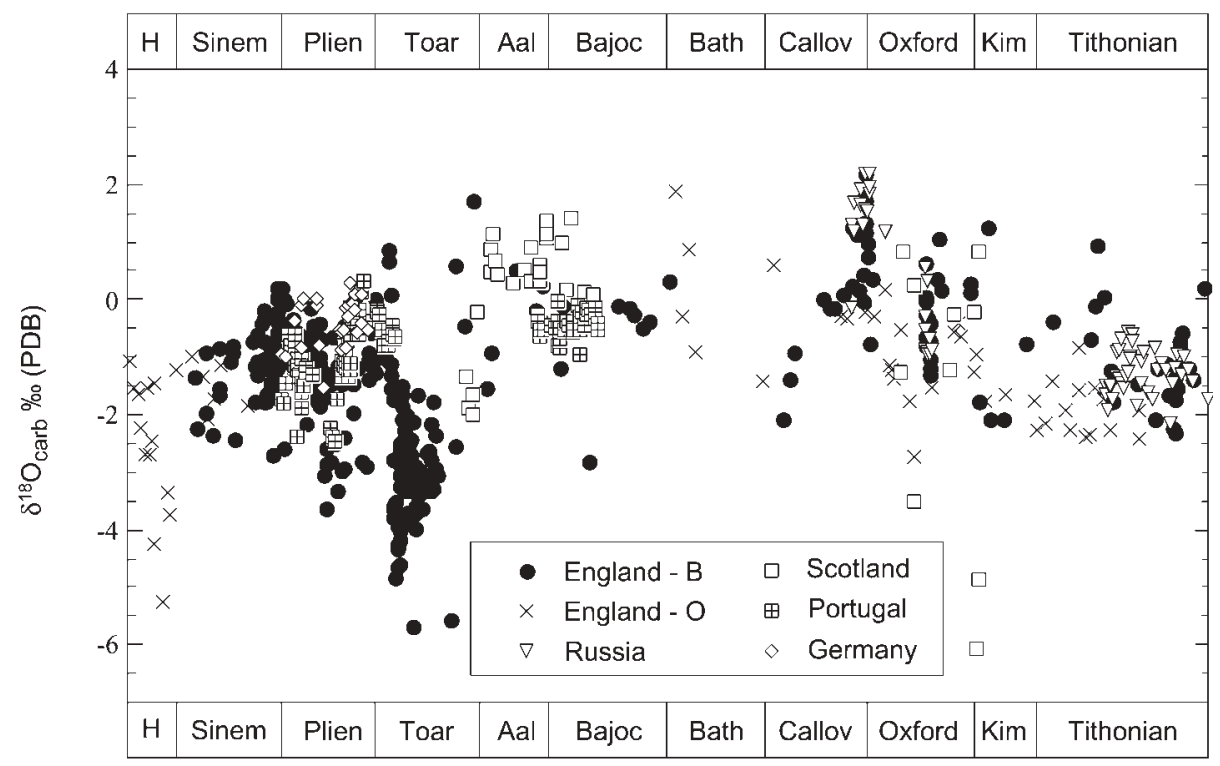

Fig. 10. Oxygen-isotope plot for the Jurassic, based on diagenetically screened (Fe $<150 \mathrm{ppm}$ ) belemnites (B) from England, Scotland, Germany, Portugal and Russia, and non-screened oysters $(\mathrm{O})$ from England. The latter dataset, although not as reliable as the former, is necessary to provide detailed coverage of the Callovian-Tithonian interval. The areas selected were relatively close to one another during Jurassic time and isotopic and temperature characteristics of the water masses should have been similar. Data from Jones et al. (1994b, c), Parkinson (1994), Podlaha et al. (1998), McArthur et al. $(2000 a)$ and Gröcke (2001). Significant features recorded in belemnites are low values of $\delta^{18} \mathrm{O}$ in early Toarcian time. The data deriving from Hettangian oysters are probably influenced by diagenesis or vital effects. A general trend towards heavier values characterizes the Sinemurian-Bajocian interval; a general trend towards lighter values characterizes the Bajocian-Tithonian interval. Conflation of datasets from different faunal provinces, with different biostratigraphical schemes, will introduce some stratigraphical error. Duration of stages is plotted according to the number of subzone units (Fig. 1). 
water. At present the world ocean is isotopically homogeneous with respect to sulphur-isotope ratios (Rees et al. 1978).

There are few data published on sulphur isotopes from sulphate in Jurassic sediments, although a high-resolution curve, derived from marine barite, now exists for the Cenozoic sequence (Paytan et al. 1998). A promising approach has utilized sulphate substituting for carbonate in Miocene microfossil tests (Burdett et al. 1989), Cretaceous limestones (Ohkouchi et al. 1999) and Carboniferous brachiopods (Kampschulte et al. 2001). Evaporites also give good results but typically lack high-resolution biostratigraphy and may have precipitated in restricted water bodies whose isotopic composition does not reflect that of the world ocean. The sedimentary sulphur cycle is coupled with the carbon cycle because both are sensitive to changing redox conditions. For example, the observed positive $\delta^{34} \mathrm{~S}$ shift at the Cenomanian-Turonian boundary can be related to selective withdrawal of ${ }^{32} \mathrm{~S}$ during bacterial pyrite fixation consequent upon widespread deposition of black shales (and coincident positive $\delta^{13} \mathrm{C}$ shift) during the Oceanic Anoxic Event (Ohkouchi et al. 1999). Similar phenomena should have characterized the early Toarcian Oceanic Anoxic Event, but the only available Jurassic $\delta^{34} \mathrm{~S}$ profiles across this interval derive from organicrich bulk sediment and probably largely reflect the isotopic composition of variable quantities of included diagenetic pyrite (Vetö et al. 1997; Ebli et al. 1998). The extant AalenianTithonian $\delta^{34} \mathrm{~S}_{\text {sulphate }}$ curve, derived from skeletal (e.g. belemnites) and bulk carbonates (Strauss 1999), is too patchy at present to allow detailed interpretation.

\section{Strontium isotopes}

The modern ${ }^{87} \mathrm{Sr} /{ }^{86} \mathrm{Sr}$ sea-water ratio of 0.7092 is primarily determined by the balance between continent-derived and mantle-derived strontium. Early segregation of continental crust left it with high rubidium/strontium ratios relative to the mantle. Because ${ }^{87} \mathrm{Rb}$ passes to ${ }^{87} \mathrm{Sr}$ via $\beta$-decay, continental rocks today have relatively higher average ${ }^{87} \mathrm{Sr} /{ }^{86} \mathrm{Sr}$ ratios than do mantle rocks. Consequently, fluvial ${ }^{87} \mathrm{Sr} /{ }^{86} \mathrm{Sr}$ ratios average 0.7119 and sea-floor hydrothermal fluids circulating through basaltic crust average ${ }^{87} \mathrm{Sr} /{ }^{86} \mathrm{Sr}$ of 0.7035 (Palmer \& Edmond 1989). A buffering effect is produced by the return into the oceans of old marine strontium from dissolution or recrystallization of carbonate sediments and limestones $\left({ }^{87} \mathrm{Sr} /{ }^{86} \mathrm{Sr} c\right.$. 0.707-0.709).

Strontium-isotope stratigraphy is founded on three guiding principles (Burke et al. 1982; Palmer \& Elderfield 1985; Elderfield 1986; McArthur 1994; Veizer et al. 1997). First, it is assumed that the ${ }^{87} \mathrm{Sr} /{ }^{86} \mathrm{Sr}$ ratio in sea water always has been, as it is at present, homogeneous throughout the oceans, this being a consequence of the long residence time of strontium compared with the short mixing times of oceanic water masses. Second, it is assumed that the ${ }^{87} \mathrm{Sr} /{ }^{86} \mathrm{Sr}$ ratio has varied systematically throughout geological time. Third, it is assumed that this isotopic ratio is accurately recorded by calcium-bearing minerals precipitated from sea water.

The first high-resolution strontium-isotope curve for the Jurassic was produced by Jones et al. $(1994 b, c)$, who analysed a series of diagenetically screened belemnites and oysters from the British successions, primarily Dorset and Yorkshire; earlier attempts (e.g. Faure et al. 1978) lacked sufficient data points and stratigraphical resolution to define the isotopic profile. Highresolution curves now exist for older periods of geological time (Veizer et al. 1999). Diagenetic screening of Jurassic skeletal material involved the rejection of samples with $>150 \mathrm{ppm} \mathrm{Fe}$, as these were considered likely to have suffered isotopic exchange registered by the precipitation of post-depositional ferroan calcite in the fossil guard or shell. Bulk-rock samples give much more scattered data (Koepnick et al. 1990), although careful leaching protocols can eliminate potentially contaminating phases such as clay minerals (Bailey et al. 2000). The original ${ }^{87} \mathrm{Sr} /{ }^{86} \mathrm{Sr}$ ratios of Jones et al. $(1994 b, c)$, with additions from Scotland, Germany, Portugal, Russia, Canada and New Zealand (Parkinson 1994; Gröcke 2001), are illustrated in Fig. 11. Critical data are still missing for the Bathonian-Callovian and upper Kimmeridgian sequences, and the amount of scatter in the data derived from Upper Jurassic sections is too great for comfort. It is not clear whether this data scatter is related to analysis of diagenetically compromised samples (oysters, for example, typically plot higher than coeval belemnites), or whether it is related to stratigraphical error and/or difficulties in intercontinental correlation.

Despite these problems, it is apparent that the Jurassic strontium-isotope curve has a well-defined structure. Hence, if an unknown piece of pristine skeletal carbonate or, better, a number of pieces of pristine skeletal carbonate collected in vertical sequence are analysed, and if the approximate biostratigraphical position is known, comparison with a reference curve may give an unambiguous age determination (e.g. Howarth \& McArthur 1997; McArthur et al. 2001). Strontium-isotope data from a number of 'unknowns' collected in stratigraphical sequence are to be preferred as, should they illustrate a rising or falling trend, this may aid in accurate dating. Furthermore, the scatter in a large dataset gives a better idea of the extent of post-depositional alteration. It is thus vital that diagenetic screening be undertaken to eliminate demonstrably altered samples because, were the original ${ }^{87} \mathrm{Sr} /{ }^{86} \mathrm{Sr}$ value to have been compromised, a spurious age determination would be made. As well as pristine skeletal carbonate, primary calcitic ooids may record original strontiumisotope variations. Examples from the Belluno Trough, Southern Alps, Italy, give Bajocian ${ }^{87} \mathrm{Sr} /{ }^{86} \mathrm{Sr}$ values in accord with the biostratigraphy (Zempolich \& Erba 1999).

As is illustrated in Fig. 11, the strontium-isotope curve plunges steeply across the Sinemurian-Pliensbachian interval, potentially allowing correlation and dating of unknown pristine carbonate to within one or two ammonite subzones for this interval (Jones et al. 1994c). The steep descent in mid- to late Bajocian time also permits comparable resolution, as does the Late Jurassic rise, but other parts of the curve are either less refined or relatively flat, as in late Toarcian, Aalenian and early Bajocian time, and hence of less use for secure dating. Nevertheless, relatively low values, such as characterize the Pliensbachian-Toarcian boundary, could be diagnostic if derived from a handful of samples. Inflection points of this type are particularly useful in fixing stratigraphical level, even if the isotopic data points are scattered to some degree.

Suggestions for specific values of ${ }^{87} \mathrm{Sr} /{ }^{86} \mathrm{Sr}$ characteristic of the basal Hettangian, basal Sinemurian, basal Pliensbachian and basal Toarcian units have been given by Weedon \& Jenkyns (1999). Similar chemostratigraphical definitions of the Sinemurian-Pliensbachian and Aalenian-Bajocian boundaries, based on analysis of belemnites from potential stratotypes, have been put forward by Hesselbo et al. (2000b) and McArthur et al. (2000b). However, when absolute values are used to define stratigraphical boundaries uncertainties may arise for those workers using different mass spectrometers and different normalization techniques, apart from any problems resulting from unrecognized diagenetic alteration in the material analysed. In essence, it would be difficult to know whether a handful of ${ }^{87} \mathrm{Sr} /{ }^{86} \mathrm{Sr}$ ratios determined on skeletal calcite for a section with incomplete biostratigraphical data were exactly comparable with published 


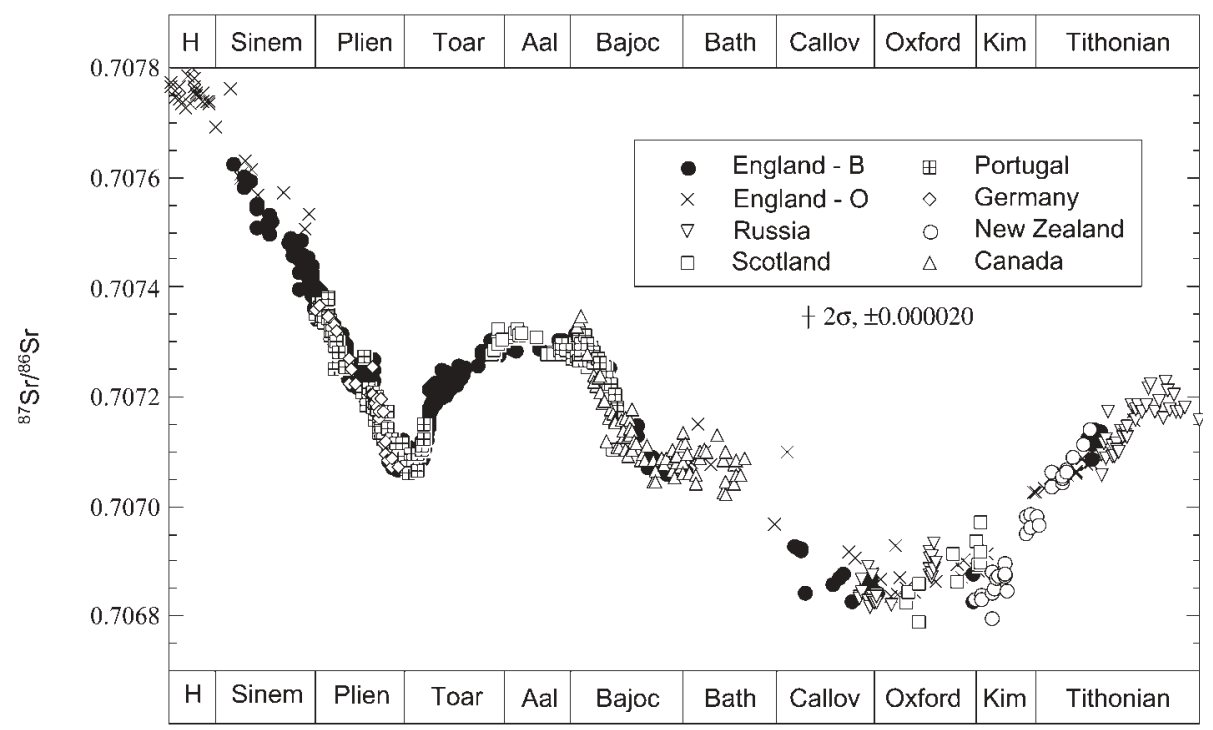

Fig. 11. Strontium-isotope curve for the Jurassic, based on diagenetically screened (Fe $<150 \mathrm{ppm}$ ) belemnites (B) from England, Scotland, Germany and Portugal, New Zealand, Russia and Canada and non-screened oysters (O) from England. The latter dataset, although not as reliable as the former (note how some values plot high), is necessary to provide detailed coverage of the Callovian-Tithonian interval. Data from Jones $e t a l$. (1994b, $c$ ), Parkinson (1994), Podlaha et al. (1998), McArthur et al. (2000a) and Gröcke (2001). Significant features are the sharp fall in ${ }^{87} \mathrm{Sr} /{ }^{86} \mathrm{Sr}$ values from Hettangian through Sinemurian and Pliensbachian time; the abrupt rise across the Pliensbachian-Toarcian boundary; the levelling out of values from mid-Toarcian to mid-Bajocian time; the subsequent fall in values to the Callovian-Oxfordian boundary, and the steady rise in ${ }^{87} \mathrm{Sr} /{ }^{86} \mathrm{Sr}$ through late Tithonian time. All samples are normalized to a value of the NBS987 standard of $0.710250\left(24 \times 10^{-6}\right.$ has been added to the published data of Jones et al. (1994b, $\left.c\right)$, which were normalized to a different standard). Conflation of datasets from different faunal provinces, with different biostratigraphic schemes, will introduce some stratigraphical error. Duration of stages is plotted according to the number of subzone units (Fig. 1).

values for materials from better-dated rocks of the same inclusive age elsewhere.

As well as providing a dating tool, strontium-isotope stratigraphy can also offer insights into variations in sedimentary accumulation rates in the stratigraphical record, as exemplified by the Lower Jurassic sequence in Dorset (Belemnite Marls and the Green Ammonite Beds; Fig. 12). There is a biostratigraphically calibrated gap at the base of the thin limestone bed known as the Hummocky, where the two highest subzones of the raricostatum Zone are missing. The limestone itself contains derived ammonites and fragments of concretions, and must have formed under conditions of very slow sedimentary rate (Sellwood 1972; Hesselbo \& Jenkyns 1995). In the overlying taylori Subzone, the rapid change in Sr-isotope ratios as a function of stratigraphical thickness suggests either a rapid rate of change of sea-water Sr-isotope ratios and/or slow accumulation rate compared with that of the overlying sediments. Given the presence of the hiatus at the base of the Belemnite Marls, the steep decline in Sr-isotope ratios, plotted against stratigraphical thickness, is best interpreted as resulting from relatively slow accumulation rates.

A very similar rapid decline in ${ }^{87} \mathrm{Sr} /{ }^{86} \mathrm{Sr}$ ratios is seen at the top of the Belemnite Marls (Fig. 12). Here there is independent evidence for a decline in the rate of sedimentation: the thicknesss of the pronounced light-dark bands decreases markedly in this part of the section and the abundance of fossils increases (Lang et al. 1928). Assuming an orbital-climatic (i.e. Milankovitch) control on sedimentation of the light-dark couplets (e.g. Weedon \& Jenkyns 1990, 1999, who interpreted them as precession cycles), their duration should be effectively constant. Hence accumulation rates of the sedimentary cycles must have slowed, allowing fossils to become relatively more concentrated. Distinct jumps in ${ }^{87} \mathrm{Sr} /{ }^{86} \mathrm{Sr}$ values (most pronounced across the Belemnite Bed, less so across the Belemnite Stone, Fig. 12) suggest the presence of hiatuses at these horizons. There is biostratigraphical evidence for the latter, in that the upper part of the luridum Subzone and the lower maculatum Subzone are missing at the base of the Green Ammonite Beds (Callomon \& Cope 1995).

Rather more unexpected is the distinct jump, or very steep rise in ${ }^{87} \mathrm{Sr} /{ }^{86} \mathrm{Sr}$ ratios across the exaratum-falciferum Subzone boundary in the section across the Jet Rock-Bituminous Shales boundary (Mulgrave Shale) in Yorkshire (Figs 5 and 13). This was detected by Jones et al. (1994c), who estimated a potential gap, between two samples $1.9 \mathrm{~m}$ apart, of $c$. 2.5 ammonite subzones, based on the average rate of change in ${ }^{87} \mathrm{Sr} /{ }^{86} \mathrm{Sr}$ observed during the late Sinemurian-early Pliensbachian interval (c. 0.000025 per Subzone). Assuming a higher rate of change of ${ }^{87} \mathrm{Sr} /{ }^{86} \mathrm{Sr}$ (c. 0.000050 per Subzone), as characteristic of the midstokesi to late apyrenum interval in Pliensbachian time, would reduce the duration of the hiatus to $c$. 1.3 Subzone units. Using the sedimentary rates for the exaratum Subzone computed by Cope (1998), on the assumption that the sub-millimetre-scale laminae in the Jet Rock were annual, would translate the duration of the gap into the likely range 200-400 ka. More detailed work across this interval by McArthur et al. (2000a) also documented the remarkably steep rise in ${ }^{87} \mathrm{Sr} /{ }^{86} \mathrm{Sr}$ values through the upper exaratum Subzone and across the boundary into the overlying falciferum Subzone. Given the implied unusual length of the exaratum Subzone, McArthur et al. suggested that it be further divided into the elegantulum, exaratum and elegans Subzones, as is the case in Germany.

This Toarcian shale-mudrock succession is in no way extraordinary, although the exaratum-falciferum boundary itself is characterized by a group of carbonate concretions (the Mill- 


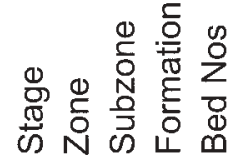

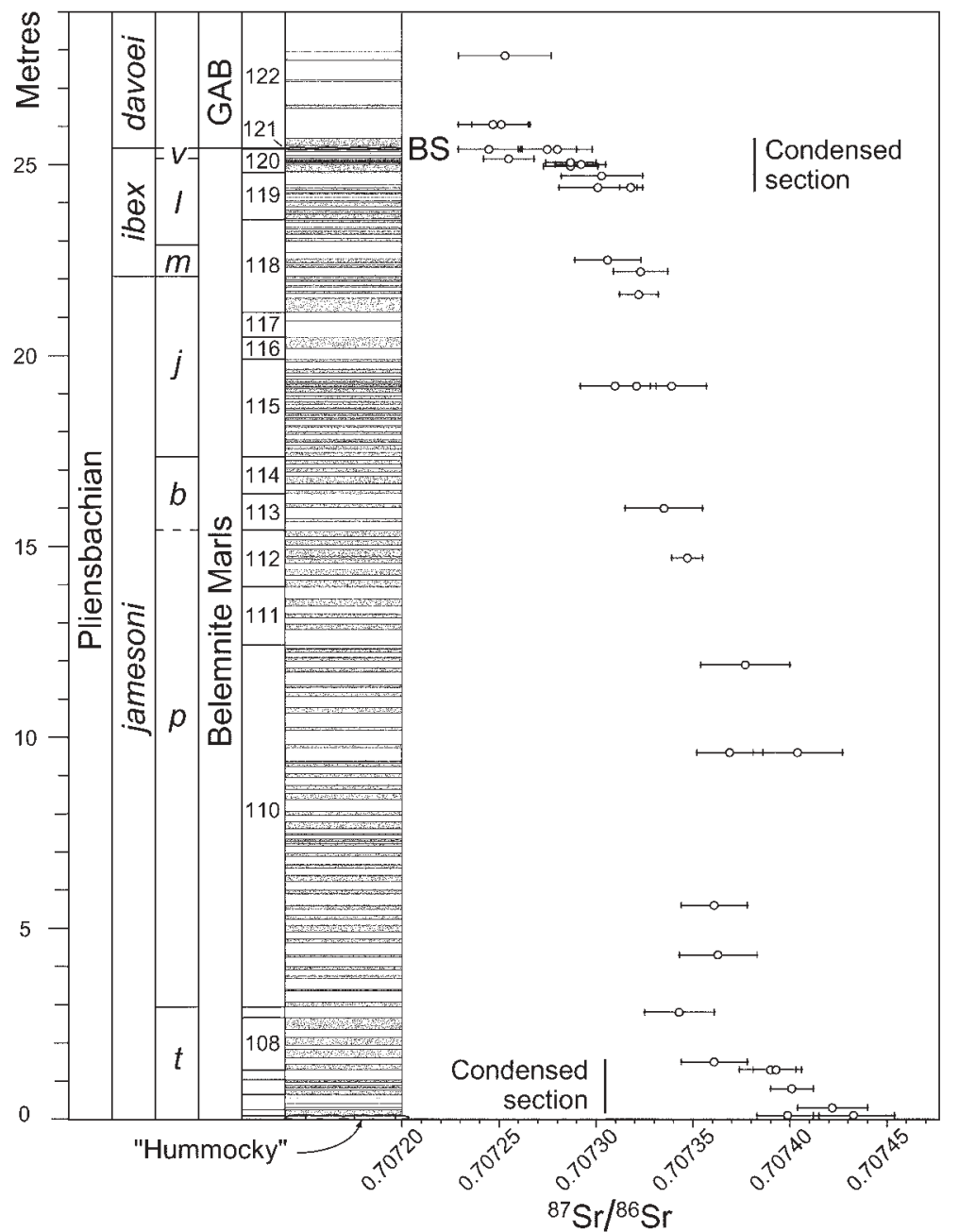

B

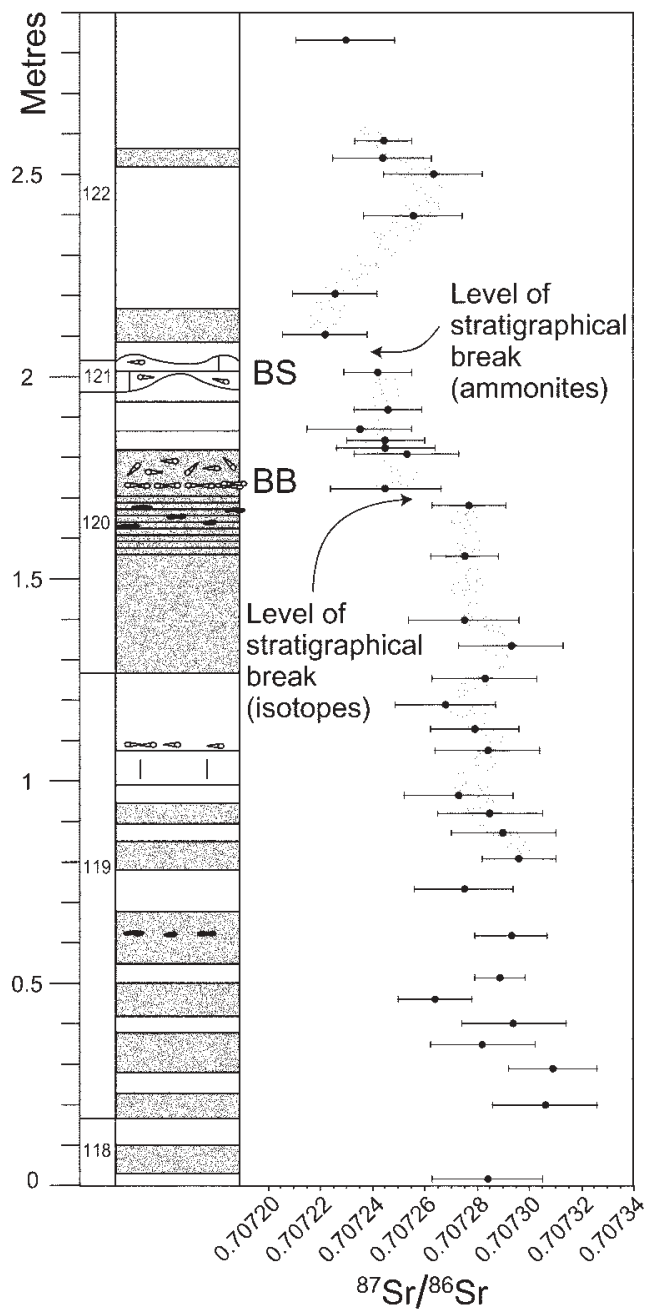

Fig. 12. (a) Strontium-isotope data, based on diagenetically screened belemnites ( $\mathrm{Fe}<150 \mathrm{ppm}$ ), plotted against the lithological log of Hesselbo \& Jenkyns (1995) through the Belemnite Marls and Green Ammonite Beds (GAB) of Dorset, England (Pliensbachian). The steep climb should be noted in ${ }^{87} \mathrm{Sr} /{ }^{86} \mathrm{Sr}$ values close to the top and bottom of the Belemnite Marls ('Hummocky' is located at the base of the section; BS, Belemnite Stone), indicating slow accumulation rates and the presence of hiatuses, as verified by the biostratigraphical evidence for sedimentary gaps. Bed numbers after Lang et al. (1928). Subzones: t, taylori; p, polymorphus; b, brevispina; j, jamesoni; $\mathrm{m}$, masseanum; 1, luridum; v, valdani. (b) Detailed strontium-isotope stratigraphy, based on a different set (note different symbol) of diagenetically screened belemnites ( $\mathrm{Fe}<150 \mathrm{ppm}$ ), across the boundary between the Belemnite Marls and the Green Ammonite Beds. Biostratigraphical data (Callomon \& Cope 1995) suggest a gap at the level of the Belemnite Stone (BS) where the ${ }^{87} \mathrm{Sr} /$ ${ }^{86} \mathrm{Sr}$ values show a small offset. A larger offset is characteristic of the Belemnite Bed (BB), which is rich in the eponymous fossil, and there is probably a gap at this level also, albeit below the level of biostratigraphical resolution. Whether the apparently cyclic pattern of change in strontium-isotope values is real or an analytical artifact, or whether it relates to unequal distribution of time in the record (reflecting gaps and changes in sedimentation rate) is not established. Bed numbers after Lang et al. (1928). Analytical errors are shown as $\pm 2 \sigma$. All samples are normalized to a value of the NBS987 standard of $0.710250\left(24 \times 10^{-6}\right.$ has been added to the published data of Jones et al. (1994c), which were normalized to a different standard. New data from Gröcke (2001). Lithological symbols as in Fig. 2.

stones) and underlain by the so-called Whalestones, of metre scale, which lie some $3 \mathrm{~m}$ lower in the section. Unlike other concretions in the Jet Rock, the Whalestones are not coated in pyrite (Morris 1980) and do not appear to have formed under conditions of sulphate reduction; they more probably represent the products of redistribution of marine carbonate, possibly influenced by methanogenesis (Raiswell 1988). The time needed to allow diffusional $\mathrm{Ca}^{2+}$ and $\mathrm{HCO}_{3}^{-}$to precipitate and form large concretions requires maintenance in the growth-promoting environment, most readily achieved during a drastic slowing or pause in sedimentation. Taken together, these phenomena suggest the presence of extremely condensed strata or a major hiatus at the exaratum-falciferum Subzone boundary, for which there is no biostratigraphical evidence.

These examples show the use of strontium-isotope stratigraphy as an indicator of condensed sections and gaps in the 


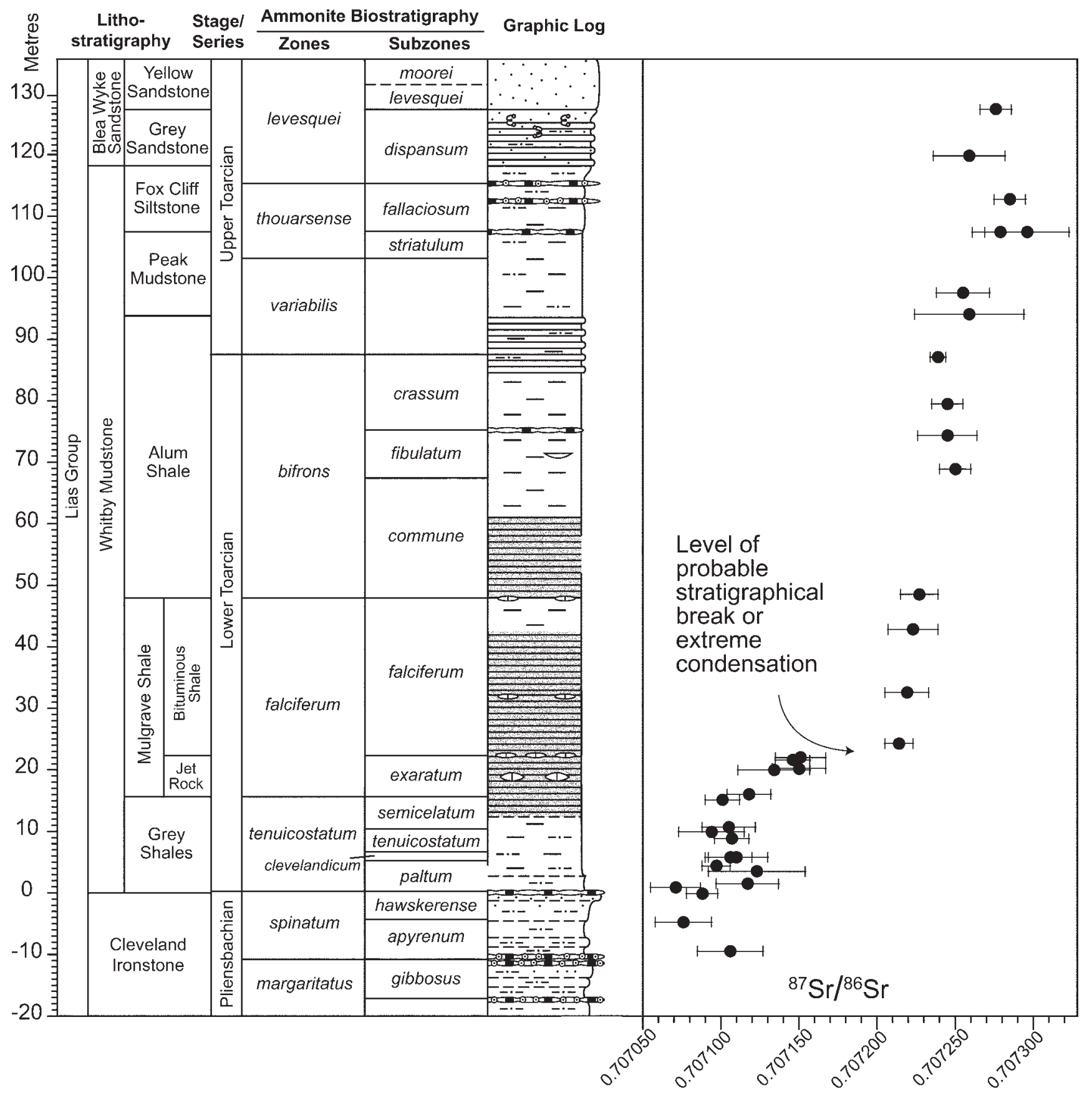

Fig. 13. Strontium-isotope data, based on diagenetically screened belemnites ( $\mathrm{Fe}<150 \mathrm{ppm}$ ) plotted against the lithological log of Hesselbo \& Jenkyns (1995) and the description of Howarth (1962) through the Jet Rock (Toarcian) of Yorkshire. Stratigraphically lower sample set (19 samples) derives from the section at Hawsker Bottoms; the stratigraphically higher dataset (14 samples) comes from Ravenscar (sections described by Howarth 1962). The abrupt jump should be noted in ${ }^{87} \mathrm{Sr} /{ }^{86} \mathrm{Sr}$ values at the exaratum-falciferum Subzone boundary, indicative of a stratigraphical gap at this level, for which there is no documented palaeontological evidence. The same feature is illustrated in the data of McArthur et al. (2000a). The relative steepness of the curve in the exaratum Subzone also indicates that this part of the section is probably condensed and/or contains a number of gaps (Fig. 5). All samples are normalized to a value of the NBS987 standard of $0.710250\left(24 \times 10^{-6}\right.$ has been added to the published data of Jones et al. (1994c), which were normalized to a different standard). Analytical errors are shown as $\pm 2 \sigma$. Lithological symbols as in Fig. 2.

record, including cases where such hiatuses are below the level of biostratigraphical resolution, and as a monitor of gross changes in sedimentary rate. As far as the controls on the strontium-isotope curve are concerned, the most important variable during Jurassic time is thought to be changing rates of sea-floor spreading and accompanying hydrothermal activity
(Jones et al. 1994c). Possible relationships between the Pliensbachian-Toarcian shift to lower and subsequent higher ${ }^{87} \mathrm{Sr} /$ ${ }^{86} \mathrm{Sr}$ values and the early Toarcian Oceanic Anoxic Event, in the context of enhanced sea-floor spreading, subduction and hydrothermal activity, were explored by Jones \& Jenkyns (2001). 


\section{Neodymium isotopes}

Because ${ }^{147} \mathrm{Sm}$ decays to ${ }^{143} \mathrm{Nd}$ (by $\alpha$-emission), the neodymium-isotope composition of a rock (its ${ }^{143} \mathrm{Nd} /{ }^{144} \mathrm{Nd}$ ratio) is a function of its initial ${ }^{143} \mathrm{Nd} /{ }^{144} \mathrm{Nd}$ ratio, its ${ }^{147} \mathrm{Sm} /{ }^{144} \mathrm{Nd}$ ratio and its age. Fractionation during early separation of the mantle and continental crust has resulted in the former having a higher ${ }^{147} \mathrm{Sm} /{ }^{144} \mathrm{Nd}$ ratio and the latter having a lower ${ }^{147} \mathrm{Sm} /{ }^{144} \mathrm{Nd}$ ratio relative to the whole-Earth average. As a result, rocks recently extracted directly from the mantle (oceanic basalts, island-arc basalts, ocean-island basalts) have the highest (most radiogenic) ${ }^{143} \mathrm{Nd} /{ }^{144} \mathrm{Nd}$ ratios. Ancient continental crust long ago inherited low ${ }^{147} \mathrm{Sm} /{ }^{144} \mathrm{Nd}$ ratios and has the lowest (least radiogenic) ${ }^{143} \mathrm{Nd} /{ }^{144} \mathrm{Nd}$ values. This situation is the opposite of the rubidium/strontium system, in which the radioactive parent $(\mathrm{Rb})$ is depleted in the mantle and concentrated in the continents, which consequently have the highest ${ }^{87} \mathrm{Sr} /{ }^{86} \mathrm{Sr}$ ratios.

Neodymium is highly insoluble in sea water and has an oceanic residence time that is approximately the same as the mixing time of the oceans $\left(10^{2}-10^{3}\right.$ years $)$. As a result, the neodymium-isotope composition of sea water varies both between and within different parts of the world ocean (Piepgras et al. 1979). The main source of neodymium to the oceans appears to be rivers or river-borne particles (Piepgras \& Wasserburg 1980; Goldstein \& Jacobsen 1987); aeolian sources appear to be relatively unimportant (Jones et al. 1994a). Hydrothermal vents from ocean ridges do not at present contribute significant neodymium to sea water, because of rapid scavenging by iron oxyhydroxide particles (Halliday et al. 1992). As the overall input to the world oceans is from continental sources, oceanic ${ }^{143} \mathrm{Nd} /{ }^{144} \mathrm{Nd}$ ratios are today relatively non-radiogenic. The residence time of neodymium is long enough that deep water masses, at least, retain their isotopic identity over considerable distances. Neodymium in North Atlantic Deep Water is little modified as it flows from its source toward the Equator (Piepgras \& Wasserburg 1987), and its imprint is still clearly seen south of $30^{\circ} \mathrm{S}$ (Jeandel 1993). Similarly, deep-water neodymium originating in the Southern Ocean is clearly seen at several levels in the Atlantic (Piepgras \& Wasserburg 1987), throughout the Indian Ocean (Bertram \& Elderfield 1993) and across large areas of the South Pacific (Aplin et al. 1986). Thus, in these cases, the neodymium-isotope composition of the deep ocean does not reflect local or even regional fluvial inputs, but rather fluvial inputs to the source areas of North Atlantic Deep Water or the mixing of Atlantic and Pacific waters in the circum-Antarctic flow of the Southern Ocean. Only the sluggish deep waters of the North Pacific apparently reflect regional fluvial inputs from young continental crustal sources (Albarède \& Goldstein 1992; Piepgras \& Jacobsen 1988). The upper few hundred metres of most oceans are commonly isotopically distinct from deeper waters, but too few data exist to assess the extent to which these differences reflect local fluvial inputs and surface-current transport. Cenozoic neodymium-isotope records show smooth, regionally reproducible variations of palaeoceanographical significance (Burton et al. 1999; M. Frank et al. 1999).

Various materials have been analysed to give Jurassic neodymium-isotope data, and all probably reflect bottom-water chemistry. These materials include skeletal calcite, fish teeth and sedimentary phosphate (carbonate fluorapatite), glauconite, and hydrothermal manganese deposits (Chyi et al. 1984; Grandjean et al. 1987; Fischer \& Gygi 1989; Stille et al. 1989, 1996; Stille $\&$ Fischer 1990). Many of these phases contain considerably more neodymium than their recent counterparts, implying that most neodymium was added during early and/or late diagenesis.
In the case of fish teeth, this process apparently takes place postmortally within a few tens of thousands of years (Toyoda \& Tokonami 1990). As such, the neodymium-isotope ratios of fish teeth appear to offer a reliable index of bottom water neodymium-isotopic variations (Shaw \& Wasserburg 1985; Martin \& Haley 2000).

A Jurassic sea-water neodymium-isotope curve is likely to have at least regional significance. At deep-ocean sites, evolving sea-water neodymium isotopes could reflect the geochemical evolution of fluvial inputs to the source area(s) of the water mass in question and/or changes in the source, depth, or relative flux of ambient currents. Most sample sites for the Jurassic period will derive from ancient shelf environments, for which there are few corresponding modern data. Waters flowing across such Jurassic shelves are likely to obtain their neodymium from deep waters impinging on the shelf or from regional fluvial inputs to the surface ocean. An interesting possibility is that, during times of development of widespread oxygen-depleted deep waters such as characterized the early Toarcian Oceanic Anoxic Event, hydrothermal inputs of neodymium would not have been fixed in iron oxyhydroxides because such phases would not have been stable. In such circumstances ocean ridges might have changed the geochemistry of the world oceans by adding large fluxes of radiogenic neodymium.

Given the abundance of fish teeth and scales in Jurassic marine sediments, there is clearly potential for using these fossils for generating high-resolution neodymium-isotope curves from a number of regions. Sedimentary phosphates and glauconite are typically associated with condensed sequences and hiatuses, with consequent loss of stratigraphical resolution; Jurassic hydrothermal manganese deposits are commonly intercalated between radiolarian cherts that are difficult to date accurately. Belemnites, as in the case of strontium-isotope stratigraphy, may be of use, as long as the effects of diagenesis can be demonstrated to be of no consequence. At present, there are no high-resolution neodymium-isotope curves for the Jurassic period, although data are more plentiful for Cretaceous and Tertiary time (Stille et al. 1996).

\section{Osmium isotopes}

The crust of the Earth has a very high rhenium/osmium ratio compared with that of the mantle or meteoritic material. Because of the decay, by $\beta$-emission, of ${ }^{187} \mathrm{Re}$ to ${ }^{187} \mathrm{Os}$, the average ${ }^{187} \mathrm{Os} /{ }^{188} \mathrm{Os}$ ratio of the continents is an order of magnitude greater than that of the mantle or meteoritic dust. Hence, similarly to the ${ }^{87} \mathrm{Sr} /{ }^{86} \mathrm{Sr}$ curve, stratigraphical variation in osmium-isotope ratios is controlled by the changing balance of fluxes from continental weathering and oceanic hydrothermal activity, as well as by dissolution of meteoritic material (Pegram et al. 1992; Ravizza 1993; Peucker-Ehrenbrink et al. 1995; Peucker-Ehrenbrink \& Ravizza 2000). Continental fluxes are dominated by relatively radiogenic osmium; hydrothermal fluids reflect relatively unradiogenic mantle sources. However, because the residence time of osmium is some two orders of magnitude less than that of strontium, this isotopic tracer will, unlike ${ }^{87} \mathrm{Sr} /$ ${ }^{86} \mathrm{Sr}$, potentially record changes in sea-water composition operating on time scales of tens of thousands of years. Also, although modern oceans are relatively homogeneous with respect to osmium isotopes, this may not necessarily have been the case for Mesozoic oceans, if they were characterized by relatively slow mixing times.

Osmium-isotope ratios have potential stratigraphical use in the Jurassic interval, as demonstrated by the work of Cohen et al. 
(1999) and Cohen \& Coe (2002), who analysed a number of samples of immature organic-rich mudrocks from Britain and found that they recorded primary sea-water signatures. Osmium levels in these rocks are much higher than general crustal abundances. The analysed material derives from the Blue Lias, the Shales-with-Beef, the Black Ven Marls (Hettangian-Sinemurian), the Jet Rock (Toarcian) and the Kimmeridge Clay (Kimmeridgian-Tithonian). Available data illustrate falling values of ${ }^{187} \mathrm{Os} /{ }^{188} \mathrm{Os}$ across the Triassic-Jurassic boundary into Hettangian time followed by a rise to more radiogenic values in Toarcian time; Kimmeridgian values are lower than Toarcian values. The current state of definition of the Jurassic osmiumisotope curve does not allow straightforward correlation with that of ${ }^{87} \mathrm{Sr} /{ }^{86} \mathrm{Sr}$. The drop in ${ }^{187} \mathrm{Os} /{ }^{188} \mathrm{Os}$ ratios across the TriassicJurassic boundary was interpreted by Cohen \& Coe (2002) as related to influx of unradiogenic osmium from weathering of fresh basalts belonging to the Central Atlantic Magmatic Province.

A particularly powerful aspect of this technique is that the same organic-rich samples yield absolute ages based on the decay of ${ }^{187} \mathrm{Rh}$ to ${ }^{187} \mathrm{Os}$, allowing direct chronometric calibration of the osmium-isotope curve (Ravizza \& Turekian 1989; Cohen et al. 1999). Useful osmium-isotope data may in future be obtainable from Jurassic metal-rich species such as manganese nodules, crusts and pisoliths in the Tethyan region (Jenkyns 1970a, b; Drittenbass 1979; Prescott 1988; Cronan et al. 1991) where these are dated to zonal level, from ferruginous concretions, such as the Bajocian 'Snuff Boxes' of Dorset and Normandy (Gatrall et al. 1972), and possibly oolitic ironstones. With the addition of many more secure data points, the osmiumisotope curve will become an increasingly useful chemostratigraphical index for the Jurassic.

\section{Conclusions}

To date, Jurassic chemostratigraphy has been predominantly a European science. Nevertheless, it has considerable promise for dating and correlation on a trans-continental scale between different faunal provinces. Black-shale events can be demonstrated to be synchronous across parts of Europe, and beyond, in the case of the Toarcian interval. Most powerful in terms of dating and correlation is a combination of strontium- and carbon-isotope stratigraphy for those parts of the Jurassic sequence characterized by steep Sr-isotope profiles and/or distinctive carbon-isotope excursions. These two parameters, coupled with TOC values, can locally give stratigraphical resolution better than that achieved by ammonites. Carbon-isotope stratigraphy in carbonate and organic matter has potential not only in marine sediments but also in lacustrine deposits containing calcite and in shallow-marine, lacustrine and non-marine sediments containing fossil wood. Correlation between calcreteand wood-bearing continental red beds and deep-marine carbonates may be possible in future for certain parts of the Jurassic record. Osmium-isotope stratigraphy, based on analyses of Jurassic organic-rich mudrocks, shows considerable promise. Sulphur-isotope stratigraphy on carbonate sediments awaits further developments. Nitrogen-isotope stratigraphy, neodymiumisotope stratigraphy, manganese, magnesium and strontium stratigraphy may also be valuable in future, at least on a local scale.

Work by Jenkyns and Hesselbo was largely sponsored by an NERCIndustrial Consortium (Rapid Global Geological Events Project). While at Oxford, Jones was supported by the Rhodes Scholarship Trust, Gröcke by ESSO and Parkinson by BP. We were aided by J. Arden, J. Cartlidge,
D. Cummins, R. Goodwin, P. Taylor, S. Wyatt and M. Whitehouse in the Oxford Isotope Laboratory. Material from the Mochras Borehole was made available courtesy of the British Geological Survey. We are grateful to A. Cohen, J. Cope, J. Hudson and J. Veizer for their reviews of this paper, and to H. Morgans-Bell for her help with Fig. 6. We gratefully acknowledge provision of samples by Anthony Challinor, Angela Coe, Russell Hall, Giselle Jakobs, Alastair Ruffell and Paul Smith.

\section{References}

Abbink, O., Targarona, J., Brinkhuis, H. \& Visscher, H. 2001. Late Jurassic to earliest Cretaceous palaeoclimatic evolution of the southern North Sea. Global and Planetary Change, 30, 231-256.

Albarède, F. \& Goldstein, S.L. 1992. World map of Nd isotopes in sea-floor ferromanganese deposits. Geology, 20, 761-763.

Altabet, M.A. \& Francois, R. 1994. Sedimentary nitrogen isotopic ratio as a recorder for surface ocean nitrate utilization. Global Biogeochemical Cycles, 8, 103-116.

Altabet, M.A., Francois, R., Murray, D.W. \& Prell, W.R. 1995. Climaterelated variations in denitrification in the Arabian Sea from sediment ${ }^{15} \mathrm{~N} /{ }^{14} \mathrm{~N}$ ratios. Nature, 373, 506-509.

Anderson, T.F., Popp, B.N., Williams, A.C., Ho, L.-Z. \& Hudson, J.D. 1994. The stable isotope records of fossils from the Peterborough Member, Oxford Clay Formation (Jurassic), UK: palaeoenvironmental implications. Journal of the Geological Society, London, 151, 125-138.

Aplin, A., Michard, A. \& Albarède, F. $1986 .{ }^{143} \mathrm{Nd} /{ }^{144} \mathrm{Nd}$ in Pacific ferromanganese encrustations and nodules. Earth and Planetary Science Letters, 81, 7-14.

Atrops, F., Gygi, R., Matyja, B.A. \& Wierzbowski, A. 1993. The Amoeboceras faunas in the Middle Oxfordian-lowermost Kimmeridgian, Submediterranean succession, and their correlation value. Acta Geologica Polonica, 43, $213-227$.

Bailey, T.R., McArthur, J.M., Prince, H. \& Thirlwall, M.F. 2000. Dissolution methods for strontium isotope stratigraphy: whole rock analysis. Chemical Geology, 167, 313-319.

Barskov, I.S. \& KiYAShKo, S.I. 2000. Thermal regime variations in the Jurassic marine basin of the East European Platform at the Callovian/Oxfordian boundary: evidence from stable isotopes in belemnite rostra. Doklady Earth Sciences, 372, 643-645.

Bartolini, A. \& CECCA, F. 1999. 20 My hiatus in the Jurassic of Umbria-Marche Apennines (Italy): carbonate crisis due to eutrophication. Comptes Rendus de l'Académie des Sciences, Paris, Sciences de la Terre et des Planètes, 329, $587-595$.

Bartolini, A., Baumgartner, P.O. \& Guex, J. 1999. Middle and Late Jurassic radiolarian palaeoecology versus carbon-isotope stratigraphy. Palaeogeography, Palaeoclimatology, Palaeoecology, 145, 43-60.

Bartolini, A., Baumgartner, P.O. \& Hunziger, J. 1996. Middle and Upper Jurassic carbon stable-isotope stratigraphy and radiolarite sedimentation of the Umbria-Marche Basin (Central Italy). Eclogae Geologicae Helvetiae, 98, $811-844$.

Baudin, F. \& LachKar, G. 1990. Géochimie organique et palynologie du Lias supérieur en zone ionienne (Grèce). Exemple d'une sédimentation anoxique conservée dans une paléo-marge en distension. Bulletin de la Societé Géologique de France, Série 8, 6, 123-132.

Baudin, F., Herbin, J.-P., Bassoulet, J.-P., Dercourt, J., Lachkar, G., Manivit, H. \& Renard, M. 1990. Distribution of organic matter during the Toarcian in the Mediterranean and Middle East. In: Huc, A.Y. (ed.) Deposition of Organic Facies. American Association of Petroleum Geologists Studies in Geology, 30, 73-91.

Bein, A. \& Binstock, R. 1985. Depositional environments and source rock potential of the Jurassic Kidod Shales, Israel. Journal of Petroleum Geology, 8, 187-198.

Bellanca, A., Masetti, D., Neri, R. \& Venezia, F. 1999. Geochemical and sedimentological evidence of productivity cycles recorded in Toarcian black shales from the Belluno Basin, Southern Alps, northern Italy. Journal of Sedimentary Research, 69B, , 466-476.

Berger, W.H. \& Vincent, E. 1986. Deep-sea carbonates: reading the carbonisotope signal. Geologische Rundschau, 75, 249-269.

Berlin, T.S., Naydin, D.P., Saks, V.N., Teis, R.V. \& Khabakov, A.V. 1967. Jurassic and Cretaceous climate in northern USSR, from paleotemperature determinations. International Geology Review, 9, 1080-1092.

Berner, R.A. 1975. The role of magnesium in the crystal growth of calcite and aragonite from sea water. Geochimica et Cosmochimica Acta, 39, 489-504.

Bernoulli, D. \& Jenkyns, H.C. 1974. Alpine, Mediterranean and Central Atlantic Mesozoic Facies in relation to the early evolution of the Tethys. In: DotT, R.H. \& Shaver, R.H. (eds) Modern and Ancient Geosynclinal Sedimentation. Special Publication of the Society of Economic Paleontologists and Miner- 
alogists, 19, 129-160.

Bertram, C.J. \& Elderfield, H. 1993. The geochemical balance of the rare earth elements and neodymium isotopes in the oceans. Geochimica et Cosmochimica Acta, 57, 1957-1986.

Bill, M., Baumgartner, P.O., Hunziker, J.C. \& Sharp, Z.D. 1995. Carbon isotope stratigraphy of the Liesberg Beds Member (Oxfordian, Swiss Jura). Eclogae Geologicae Helvetiae, 88, 135-155.

Bombardiere, L. \& Gorin, G.E. 2000. Stratigraphical and lateral distribution of sedimentary organic matter in Upper Jurassic carbonates of SE France. Sedimentary Geology, 132, 177-203.

Bucefalo Palliani, R. \& Mattioli, E. 1994. Enrichment in organic matter within the Early Toarcian Marne di Monte Serrone Formation: a synchronous event in the Umbria-Marche Basin (Central Italy). Palaeopelagos, 4, $129-140$.

Burdett, J.K., Arthur, M.A. \& Richardson, M. 1989. A Neogene seawater sulfur isotope curve from calcareous pelagic microfossils. Earth and Planetary Science Letters, 94, 189-198.

Burke, W.H., Denison, R.E., Hetherington, E.A., Koepnick, R.B., Nelson, H.F. \& Отто, J.В. 1982. Variation of seawater ${ }^{87} \mathrm{Sr} /{ }^{86} \mathrm{Sr}$ throughout Phanerozoic time. Geology, 10, 515-519.

Burton, K.W., Lee, D.C., Christensen, J.N., Halliday, A.N. \& Hein, J.R. 1999. Actual timing of neodymium isotopic variations recorded by $\mathrm{Fe}-\mathrm{Mn}$ crusts in the western North Atlantic. Earth and Planetary Science Letters, 171, 149-156

Callomon, J.H. \& Cope, J.C.W. 1995. The Jurassic Geology of Dorset. In: TAYLOR, P.D. (ed.) Field Geology of the British Jurassic. Geological Society, London, 51-103.

Carrigan, W.J., Cole, G.A., Colling, E.L. \& Jones, P.J. 1995. Geochemistry of the Upper Jurassic Tuwaiq Mountain and Hanifa Formation petroleum source rocks of eastern Saudi Arabia. In: KATZ, B.J. (ed.) Petroleum Source Rocks. Springer, Berlin, 67-87.

Cecca, F., Savary, B., Bartolini, A., Remane, J. \& Cordey, F. 2001. The Middle Jurassic-Lower Cretaceous Rosso Ammonitico succession of Monte Inici (Trapanese domain, estern Sicily): sedimentology, biostratigraphy and isotope stratigraphy. Bulletin de la Société Géologique de France, 172, $647-660$.

Chave, K.E. 1954. Aspects of the biogeochemistry of magnesium, 1. Calcareous marine organisms. Journal of Geology, 62, 266-283.

Chyi, M.S., Crerar, D., Carlson, R.W. \& Stallard, R.F. 1984. Hydrothermal Mn-deposits of the Franciscan Assemblage: II. Isotope and trace element geochemistry and implications for hydrothermal convection at spreading centers. Earth and Planetary Science Letters, 71, 31-45.

Clarke, L.J. \& Jenkyns, H.C. 1999. New oxygen-isotope evidence for long-term Cretaceous climatic change in the Southern Hemisphere. Geology, 27, 699-702.

Cohen, A.S. \& CoE, A.L. 2002. New geochemical evidence for the onset of volcanism in the Central Atlantic magmatic province and environmental change at the Triassic-Jurassic boundary. Geology, 30, 267-270.

Cohen, A.S., Coe, A.L., Bartlett, J.M. \& Hawkesworth, C.J. 1999. Precise $\mathrm{Re}-\mathrm{Os}$ ages of organic-rich mudrocks and the Os isotope composition of Jurassic seawater. Earth and Planetary Science Letters, 167, 159-173.

Cope, J.C.W. 1967. The palaeontology and stratigraphy of the lower part of the Upper Kimmeridge Clay of Dorset. Bulletin of the British Museum (Natural History), Geology Series, 15, 1-79.

CopE, J.C.W. 1974. Upper Kimmeridgian ammonites of the Wash area and a subzonal scheme for the lower part of the Upper Kimmeridgian. Bulletin of the Geological Survey of Great Britain, 47, 29-37.

Cope, J.C.W. 1998. Discussion on estimates of the amount and rate of sea-level change across the Rhaetian-Hettangian and Pliensbachian-Toarcian boundaries (latest Triassic to early Jurassic); reply by Hallam, A. Journal of the Geological Society, London, 155, 421-422.

Cope, J.C.W., Duff, K.L., Parsons, C.F., Torrens, H.S., Wimbledon, W.A. \& Wright, J.K. 1980a. A Correlation of Jurassic Rocks in the British Isles. Part One: Introduction and Lower Jurassic. Special Report of the Geological Society, London, 14.

Cope, J.C.W., Getty, T.A., Howarth, M.K., Morton, N. \& Torrens, H.S. 1980b. A Correlation of Jurassic Rocks in the British Isles. Part Two: Middle and Upper Jurassic. Special Report of the Geological Society, London, 15.

Corbin, J.-C. 1994. Evolution géochimique du jurassique du sud-est de la France: influence des variations du niveau marin et de la téctonique. Thesis, Université de Paris VI.

Corbin, J.-C., Person, A., Iatzoura, A., Ferré, B. \& Renard, M. 2000. Manganese in pelagic carbonates: indication of major tectonic events during the geodynamic evolution of a passive continental margin (the Jurassic European margin of the Tethys-Ligurian Sea). Palaeogeography, Palaeoclimatology, Palaeoecology, 156, 123-138.

Cox, B.M. \& Gallois, R.W. 1981. The stratigraphy of the Kimmeridge Clay of the Dorset type area and its correlation with some other Kimmeridgian sequences. Report of the Institute of Geological Sciences, 80/4, 1-44.

Cronan, D.S., Galácz, A., Mindszenty, A., Moorby, A. \& Polgari, M. 1991. Tethyan ferromanganese oxide deposits from Jurassic rocks in Hungary. Journal of the Geological Society, London, 148, 655-668.

Danelian, T. \& Baudin, F. 1990. Découverte d'un horizon carbonaté, riche en matière organique, au sommet des radiolarites d'Épire (zone ionienne, Grèce): le Membre de Paliambela. Comptes Rendus de l'Académie des Sciences, Paris, Série II, 311, 421-428.

De Graciansky, P.-C., Dardeau, G., Bodeur, Y. \& 5 others 1998. Les Terres Noires du Sud-Est de la France (Jurassique moyen et supérieur): interprétation en termes de stratigraphie séquentielle. Bulletin du Centre de Recherches Elf Exploration-Production, 22, 35-66.

Demaison, G. \& Moore, G.T. 1980. Anoxic environments and oil source bed genesis. AAPG Bulletin, 64, 1179-1209.

De Rafelis, M., Emmanuel, L., Renard, M., Atrops, F. \& Jan du Chene, R. 2001. Geochemical characterization (MnO content) of third order eustatic sequences in Upper Jurassic pelagic carbonates of the Vocontian Trough (SE France). Eclogae Geologicae Helvetiae, 94, 145-152.

De Wever, P. \& Baudin, R. 1996. Palaeogeography of radiolarite and organic-rich deposits in Mesozoic Tethys. Geologische Rundschau, 85, 310-326.

Drittenbass, W. 1979. Sedimentologie und Geochemie von Eisen-Mangan führenden-Knollen und Krusten im Jura der Trento-Zone (östliche Südalpen, Norditalien). Eclogae Geologicae Helvetiae, 72, 313-345.

Dromart, G., Crumière, J.-P., Elmi, S. \& Espitalié, J. 1989. Géodynamique et potentialités pétrolières d'une marge de bassin: le Jurassique de la bordure ardéchoise (France Sud-Est). Comptes Rendus de l'Académie des Sciences, Paris, Série II, 309, 1495-1502.

DuARTE, L.V. 1998. Clay minerals and geochemical evolution in Toarcian-Lower Aalenian of the Lusitanian Basin (Portugal). Cuadernos de GeologÍa Ibérica, 24, 69-98.

Dulai, A., Suba, Z. \& Szarka, S. 1992. Toarcian (Lower Jurassic) organic-rich black shale in the Réka Valley (Mecsek Hills, Hungary). Földani Közlöny, 122, 67-87.

DypviK, H. 1985. Jurassic and Cretaceous black shales of the Janusfjellet Formation, Svalbard, Norway. Sedimentary Geology, 41, 235-248.

Ebli, O., Vetö, I., Lobitzer, H., SAJgó, C., Demény, A. \& Hetényi, M. 1998. Primary productivity and early diagenesis in the Toarcian Tethys on the example of the Mn-rich black shales of the Sachrang Formation, Northern Calcareous Alps. Organic Geochemistry, 29, 1635-1647.

Ekart, D.D., Cerling, T.E., Montañez, I.P. \& Tabor, N.J. 1990. A 400 million year carbon isotope record of pedogenic carbonate: implications for paleoatmospheric carbon dioxide. American Journal of Science, 299, $805-827$.

Elderfield, H. 1986. Strontium isotope stratigraphy. Palaeogeography, Palaeoclimatology, Palaeoecology, 57, 71-90.

Elmi, S., Goy, A., Mouterde, P., Rivas, P. \& Rocha, R. 1989. Correlaciones bioestratigráficas en el Toarciense de la Peninsula Ibérica. Cuadernos de Geología Ibérica, 13, 265-277.

Espitalié, J., Marquis, F. \& Sage, L. 1987. Organic geochemistry of the Paris Basin. In: Brooks, J. \& Glennie, K. (eds) Petroleum Geology of North West Europe. Geological Society, London, 1, 71-86.

FARQUharson, G.W. 1983. The Nordenskjöld Formation on the northern Antarctic peninsular: an Upper Jurassic radiolarian mudstone and tuff sequence. British Antarctic Survey Bulletin, 60, 1-22.

Faure, G., Assereto, R. \& Tremba, E.L. 1978. Strontium isotope composition of marine carbonates of Middle Triassic to Early Jurassic age, Lombardic Alps, Italy. Sedimentology, 25, 523-543.

FIscher, H. \& GygI, R. 1989. Numerical and biochronological time scales correlated at the ammonite subzone level; $\mathrm{K}-\mathrm{Ar}, \mathrm{Rb}-\mathrm{Sr}$ ages, and $\mathrm{Sr}, \mathrm{Nd}$, and $\mathrm{Pb}$ sea-water isotopes in an Oxfordian (Late Jurassic) succession of northern Switzerland. Geological Society of America Bulletin, 101, 1584-1597.

Fisher, I.St.J. \& Hudson, J.D. 1987. Pyrite formation in Jurassic shales of contrasting biofacies. In: Brooks, J. \& FleEt, A.J. (eds) Marine Petroleum Source Rocks. Geological Society, London, Special Publications, 26, 69-78.

Fleet, A.J., Clayton, C.J., Jenkyns, H.C. \& Parkinson, D.N. 1987. Liassic source-rock deposition in western Europe. In: Brooks, J. \& GlenniE, K.W. (eds) Petroleum Geology of North West Europe. Graham and Trotman, London, 1, 59-70.

Fowler, M.G. \& MCAlpine, K.D. 1995. The Egret Member, a prolific Kimmeridgian source rock from offshore Eastern Canada. In: KATZ, B.J. (ed.) Petroleum Source Rocks. Springer, Berlin, 111-130.

Frank, M., O'Nions, R.K., Hein, J.R. \& BanaKaR, V.K. 1999. 60 Myr records of major elements and $\mathrm{Pb}-\mathrm{Nd}$ isotopes from hydrogenous ferromanganese crusts: reconstruction of seawater paleochemistry. Geochimica et Cosmochimica Acta, 63, 1689-1708.

Frank, T.D., Arthur, M.A. \& Dean, W.E. 1999. Diagenesis of Lower Cretaceous pelagic carbonates, North Atlantic: paleoceanographic signals obscured. 
Journal of Foraminiferal Research, 29, 340-351.

FRITZ, P. 1965. O ${ }^{18} / \mathrm{O}^{16}$-Isotopenanalysen und Paleotemperaturbestimmungen an Belemniten aus dem schwäb. Jura. Geologische Rundschau, 54, 261-269.

Gallois, R.W. 1978. A pilot study of oil shale occurrences in the Kimmeridge Clay. Report of the Institute of Geological Sciences, 78/13, 1-26.

GalloIs, R.W. \& Cox, B.M. 1974. Stratigraphy of the Upper Kimmeridge Clay of the Wash area. Bulletin of the Geological Survey of Great Britain, 47, 1-28.

Ganeshram, R.S., Pedersen, T.F., Calvert, S.E., McNeill, G.W. \& Fontugne, M.R. 2000. Glacial-interglacial variability in denitrification in the world's oceans: causes and consequences. Paleoceanography, 15, 361-376.

Gatrall, M., Jenkyns, H.C. \& Parsons, C.F. 1972. Limonitic concretions from the European Jurassic with particular reference to the 'Snuff-Boxes' of Southern England. Sedimentology, 18, 79-103.

Goldstein, S.J. \& JACOBSEN, S.B. 1987. The Nd and Sr isotopic systematics of river-water dissolved material: implications for the sources of $\mathrm{Nd}$ and $\mathrm{Sr}$ in seawater. Chemical Geology, 66, 245-272.

Graham, D.W., Bender, M.L., Williams, D.F. \& Keigwin, L.D. JR 1982. Strontium-calcium ratios in Cenozoic planktonic foraminifera. Geochimica et Cosmochimica Acta, 46, 1281-1292.

Grandjean, P., Cappetta, H., Michard, A. \& Albarède, F. 1987. The assessment of REE patterns and ${ }^{143} \mathrm{Nd} /{ }^{144} \mathrm{Nd}$ ratios in fish remains. Earth and Planetary Science Letters, 84, 181-196.

GRöcKE, D. 2001. Isotope stratigraphy and ocean-atmosphere interactions in the Jurassic and Early Cretaceous. D.Phil. thesis, University of Oxford.

Gröcke, D., Hesselbo, S.P. \& Jenkyns, H.C. 1999. Carbon-isotope composition of Lower Cretaceous fossil wood: ocean-atmosphere chemistry and relation to sea-level change. Geology, 27, 155-158.

GRUSZCZYŃSKI, M. 1998. Chemistry of Jurassic seas and its bearing on the existing organic life. Acta Geologica Polonica, 48, 1-29.

Guex, J. 1973. Aperçu biostratigraphique sur le Toarcien inférieur du Moyen-Atlas marocain et discussion sur la zonation de ce sous-étage dans les series méditerranéennes. Eclogae Geologicae Helvetiae, 66, 493-523.

Hallam, A. 1960. A sedimentary and faunal study of the Blue Lias of Dorset and Glamorgan. Philosophical Transactions of the Royal Society, London, B243, $1-44$.

Hallam, A. 1981. A revised sea-level curve for the Early Jurassic. Journal of the Geological Society, London, 138, 735-743.

Hallam, A. 1987. Mesozoic marine organic-rich shales. In: Brooks, J. \& FleEt, A.J. (eds) Marine Petroleum Source Rocks. Geological Society, London, Special Publications, 26, 251-261.

Hallam, A. 1995. Oxygen-restricted facies of the basal Jurassic of north west Europe. Historical Biology, 10, 247-257.

Halliday, A.N., Davidson, J.P., Holden, P., Owen, R.M. \& Olivarez, A.M. 1992. Metalliferous sediments and the scavenging residence time of $\mathrm{Nd}$ near hydrothermal vents. Geophysical Research Letters, 19, 761-764.

Hantzpergue, P., Baudin, F., Mitta, A., Olferiev, A. \& Zakharov, V. 1998. The Upper Jurassic of the Volga Basin: ammonite biostratigraphy and occurrence of organic-carbon rich facies. Correlations between borealsubboreal and submediterranean provinces. In: Crasouin-SolEAU, S. \& Barrier, É. (eds) Péri-Tethys Memoir 4: Epicratonic Basins of Peri-Tethyan Platforms. Mémoires du Muséum National d'Histoire Naturelle, 179, 9-33.

Hasegawa, T. 1997. Cenomanian-Turonian carbon isotope events recorded in terrestrial organic matter from northern Japan. Palaeogeography, Palaeoclimatology, Palaeoecology, 130, 251-273.

Herbin, J.P. \& Geyssant, J.R. 1993. 'Ceintures organiques' au Kimmeridgien/ Tithonien en Angleterre (Yorkshire, Dorset) et en France (Boulonnais). Comptes Rendus de l'Académie des Sciences, Paris, Série II, 317, $1309-1316$.

Herbin, J.P., Fernandez-Martinez, J.L., Geyssant, J.R. \& 5 others 1995. Sequence stratigraphy of source rocks applied to the study of the Kimmeridgian/Tithonian in the north-west European shelf (Dorset/UK, Yorkshire/UK and Boulonnais/France). Marine and Petroleum Geology, 12, 177-194.

Herbin, J.P., Müller, C., Geyssant, J.R., Mélières, F., Penn, I.E. \& Yorkim GROUP 1993. Variation of the distribution of organic matter within a transgressive system tract: Kimmeridge Clay (Jurassic), England. In: KATZ, B.J. \& PratT, L.M. (eds) Source Rocks in a Sequence Stratigraphic Framework. American Association of Petroleum Geologists Studies in Geology, 37, 67-100.

Hesselbo, S.P. \& Jenkyns, H.C. 1995. A comparison of the Hettangian to Bajocian successions of Dorset and Yorkshire. In: TAYLoR, P.D. (ed.) Field Geology of the British Jurassic. Geological Society, London, 105-150.

Hesselbo, S.P. \& Jenkyns, H.C. 1998. British Lower Jurassic sequence stratigraphy. In: DE Graciansky, P.C., Hardenbol, J., JACQuin, T., FARley, M. \& VAIL, P.R. (eds) Mesozoic-Cenozoic Sequence Stratigraphy of European Basins. Special Publication of the Society for Sedimentary Geology (SEPM), 60, 561-581

Hesselbo, S.P., Jenkyns, H.C. \& OAtes, M.J. 1998. The lower Lias Group of the Hebrides Basin. Scottish Journal of Geology, 34, 23-60.
Hesselbo, S.P., Gröcke, D., Jenkyns, H.C., Buerrum, C.J., Farrimond, P., Morgans Bell, H.S. \& Green, O. 2000a. Massive dissociation of gas hydrate during a Jurassic Oceanic Anoxic Event. Nature, 406, 392-395.

Hesselbo, S.P., Meister, C. \& Gröcke, D. 2000b. A potential global stratotype for the Sinemurian-Pliensbachian boundary (Lower Jurassic), Robin Hood's Bay, UK: ammonite faunas and isotope stratigraphy. Geological Magazine, 137, 601-607.

Hesselbo, S.P., Robinson, S.A., Surlyk, F. \& Piasecki, S. 2002. Terrestrial and marine extinction at the Triassic-Jurassic boundary synchronized with major carbon-cycle perturbation: a link to initiation of massive volcanism? Geology, 30, 251-254.

Hoffman, A., Gruszczynski, M., Malkowski, K., Halas, S., Matyja, B.A. \& Wierbowski, A. 1991. Carbon and oxygen isotope curves for the Oxfordian of central Poland. Acta Geologica Polonica, 43, 157-164.

Hollander, D.J., Bessereau, G., Belin, S. \& Huc, A.Y. 1991. Organic matter in the Early Toarcian shales, Paris Basin, France: a response to environmental changes. Revue de l'Institut Français du Pétrole, 46, 543-562.

Holmes, M.E., Schneider, R.R., Müller, P.J., Segl, M. \& Wefer, G. 1997. Reconstruction of past nutrient utilization in the eastern Angola Basin based on sedimentary ${ }^{15} \mathrm{~N} /{ }^{14} \mathrm{~N}$ ratios. Paleoceanography, 12, 604-614.

HoRI, R.S. 1997. The Toarcian radiolarian event in bedded cherts from southwestern Japan. Marine Micropaleontology, 30, 159-169.

Howarth, M.K. 1962. The Jet Rock Series and the Alum Shale Series of the Yorkshire Coast. Proceedings of the Yorkshire Geological Society, 33, $381-422$.

Howarth, M.K. 1992. The Ammonite Family Hildoceratidae in the Lower Jurassic of Britain. Part 1. Monograph of the Palaeontographical Society, London.

Howarth, R.J. \& McArthur, J.M. 1997. Statistics for strontium isotope stratigraphy: a robust LOWESS fit to the marine Sr-isotope curve for 0 to $206 \mathrm{Ma}$, with look-up table for derivation of numeric age. Journal of Geology, 105, 441-456.

Huc, A.Y., Lallier-Verges, E., Bertrand, P., Carpentier, B. \& Hollander, D.J. 1992. Organic matter response to change of depositional environment in Kimmeridgian Shales. In: Whelan, J.K. \& Farrington, J.W. (eds) Organic Matter: Productivity, Accumulation, and Preservation in Recent and Ancient Sediments. Columbia University Press, New York, 469-486.

Hudson, J.D. \& Anderson, T.F. 1989. Ocean temperatures and isotopic compositions through time. Transactions of the Royal Society of Edinburgh: Earth Sciences, 80, 183-192.

Hudson, J.D. \& MarTIL, D.M. 1991. The Lower Oxford Clay: production and preservation of organic matter in the Callovian (Jurassic) of central England. In: Tyson, R.V. \& Pearson, T.H. (eds) Modern and Ancient Continental Shelf Anoxia. Geological Society, London, Special Publications, 58, 363-397.

Hvoslef, S., Dypik, H. \& Solli, H. 1985. A combined sedimentological and organic geochemical study of the Jurassic/Cretaceous Janusfjellet Formation (Svalbard), Norway. Organic Geochemistry, 10, 101-111.

IvimEY-CooK, H.C. 1971. Stratigraphical palaeontology of the Lower Jurassic of the Llanbedr (Mochras Farm) Borehole. In: WoodLand, A.W. (ed.) The Llanbedr (Mochras Farm) Borehole. Report of the Institute of Geological Sciences, 71/18, 87-92.

IvIMEY-CooK, H.C. 1982. Biostratigraphy of the Lower Jurassic and Upper Triassic (Rhaetian) rocks of the Winterborne Kingston borehole, Dorset. In: RHYS, G.H., LotT, G.K. \& CALver, M.A. (eds) The Winterborne Kingston Borehole, Dorset, England. Report of the Institute of Geological Sciences, $\mathbf{8 1 / 3}, 97-106$.

JEANDEL, C. 1993. Concentration and isotopic composition of $\mathrm{Nd}$ in the South Atlantic Ocean. Earth and Planetary Science Letters, 117, 581-591.

JENKYNS, H.C. 1970a. Submarine volcanism and the Toarcian iron pisolites of western Sicily. Eclogae Geologicae Helvetiae, 63, 741-774.

JenKyns, H.C. 1970b. Fossil manganese nodules from the west Sicilian Jurassic. Eclogae Geologicae Helvetiae, 63, 741-774.

Jenkyns, H.C. 1985. The early Toarcian and Cenomanian-Turonian anoxic events in Europe: comparisons and contrasts. Geologische Rundschau, 74, 505-518.

JENKYNS, H.C. 1988. The early Toarcian (Jurassic) anoxic event: stratigraphic, sedimentary, and geochemical evidence. American Journal of Science, 288, $101-151$.

JENKYNS, H.C. 1996. Relative sea-level change and carbon isotopes: data from the Upper Jurassic (Oxfordian) of central and Southern Europe. Terra Nova, 8, 75-85.

JENKYNS, H.C. 1997. Mesozoic anoxic events and palaeoclimate. Zentralblatt für Geologie und Paläontologie, 1999, 943-949.

Jenkyns, H.C. \& Clayton, C.J. 1986. Black shales and carbon isotopes in pelagic sediments from the Tethyan Lower Jurassic. Sedimentology, 33, 87-106.

Jenkyns, H.C. \& Clayton, C.J. 1997. Lower Jurassic epicontinental carbonates and mudstones from England and Wales: chemostratigraphic signals and the early Toarcian anoxic event. Sedimentology, 44, 687-706.

JENKYNS, H.C. \& SENIOR, J.R. 1991. Geological evidence for intra-Jurassic faulting in the Wessex Basin and its margins. Journal of the Geological Society, 
London, 148, 245-260.

Jenkyns, H.C., Gale, A.S. \& CoRfield, R.M. 1994. Carbon- and oxygen-isotope stratigraphy of the English Chalk and Italian Scaglia and its palaeoclimatic significance. Geological Magazine, 131, 1-34.

Jenkyns, H.C., GÉcZY, B. \& MarshaLL, J.D. 1991. Jurassic manganese carbonates of central Europe and the early Toarcian anoxic event. Journal of Geology, 99, 137-149.

JenKYNS, H.C., GröcKe, D. \& Hesselbo, S.P. 2001. Nitrogen isotope evidence for water mass denitrification during the early Toarcian Oceanic Anoxic Event. Paleoceanography, 16, 593-603.

Jenkyns, H.C., Sarti, M., Masetti, D. \& Howarth, M.K. 1985. Ammonites and stratigraphy of Lower Jurassic black shales and pelagic limestones from the Belluno Trough, Southern Alps, Italy. Eclogae Geologicae Helvetiae, 78, 299-311.

JiméneZ, A.P., Jiménez de Cisneros, C., Rivas, P. \& Vera, J.A. 1996. The Early Toarcian anoxic event in the westernmost Tethys (Subbetic): paleogeographic and paleobiogeographic significance. Journal of Geology, 104, 399-416.

Jones, C.E. 1992. Strontium isotopes in Jurassic and early Cretaceous seawater. D.Phil. thesis, University of Oxford.

Jones, C.E. \& JenKyns, H.C. 2001. Seawater strontium isotopes, oceanic anoxic events, and seafloor hydrothermal activity in the Jurassic and Cretaceous. American Journal of Science, 301, 112-149.

Jones, C.E., Halliday, A.N., Rea, D.K. \& Owen, R.M. 1994a. Neodymium isotopic variations in North Pacific modern silicate sediment and the insignificance of detrital REE contributions to seawater. Earth and Planetary Science Letters, 127, 55-66.

Jones, C.E., Jenkyns, H.C., Coe, A.L. \& Hesselbo, S.P. 1994b. Sr-isotopic variations in Jurassic and Cretaceous seawater. Geochimica et Cosmochimica Acta, 58, 3061-3074.

Jones, C.E., Jenkyns, H.C. \& Hesselbo, S.P. 1994c. Strontium isotopes in Early Jurassic seawater. Geochimica et Cosmochimica Acta, 58, 1285-1301.

Kampschulte, A., Bruckschen, P. \& Strauss, H. 2001. The sulphur isotopic composition of trace sulphates in Carboniferous brachiopods: implications for coeval seawater, correlation with other geochemical cycles and isotope stratigraphy. Chemical Geology, 175, 149-173.

KATZ, A. 1973. The interaction of magnesium with calcite during crystal growth at one atmosphere. Geochimica et Cosmochimica Acta, 37, 1563-1587.

KeniG, F., Hayes, J.M., PopP, B.N. \& Summons, R.E. 1994. Isotopic biogeochemistry of the Oxford Clay Formation (Jurassic), UK. Journal of the Geological Society, London, 151, 139-152.

Kennedy, M.J., Pevear, D.R. \& Hill, R.J. 2001. Mineral surface control of organic carbon in black shale. Science, 295, 657-660

КосH, P.L., Zachos, J.C. \& Gingerich, P.D. 1992. Correlation between isotope records in marine and continental carbon reservoirs near the Palaeocene/ Eocene boundary. Nature, 358, 319-322.

Koepnick, R.B., Denison, R.E., Burke, W.H., Hetherington, E.A. \& Dahl, D.A. 1990. Construction of the Triassic and Jurassic portion of the Phanerozoic curve of seawater ${ }^{87} \mathrm{Sr} /{ }^{86} \mathrm{Sr}$. Chemical Geology, 80, 327-349.

KüSPERT, W. 1982. Environmental changes during oil shale deposition as deduced from stable isotope ratios. In: Einsele, G. \& Seilacher, A. (eds) Cyclic and Event Stratification. Springer, Berlin, 482-501.

KüsPERT, W. 1983. Faziestypen des Posidonienschiefer. Eine isotopengeologische, organisch-chemische und petrographische Studie. Thesis, University of Tübingen.

Lang, W.D., Spath, L.F., Cox, R.L. \& Muir Wood, H.M. 1928. The Belemnite Marls of Charmouth, a series in the Lias of the Dorset Coast. Quarterly Journal of the Geological Society, London, 84, 179-257.

Lea, D.W., Mashiotta, T.A. \& Spero, H.J. 1999. Controls on magnesium and strontium uptake in planktonic foraminifera determined by live culturing. Geochimica et Cosmochimica Acta, 63, 2369-2379.

Lear, C.H., Elderfield, H. \& Wilson, P.A. 2000. Cenozoic deep-sea temperatures and global ice volumes from $\mathrm{Mg} / \mathrm{Ca}$ in benthic foraminiferal calcite. Science, 287, 269-272.

Leith, T.L., WeIss, H.M., MørK, A. \& 10 others 1992. Mesozoic hydrocarbon sourse-rocks of the Arctic region. In: Vorren, T.O., Bergsager, E., DahLStammes, Ø.A., Holter, E., Johansen, B., Lie, E. \& Lund, T.B. (eds) Arctic Geology and Petroleum Potential. Proceedings of the Norwegian Petroleum Society Conference, August 1990, Tromsø, Norway. Norwegian Petroleum Society Special Publication, 2, 1-25.

McArthur, J.M. 1994. Recent trends in strontium isotope stratigraphy. Terra Nova, 6, 331-358

McArthur, J.M., Donovan, D.T., Thirlwall, M.F., Fouke, B.W. \& Mattey, D. 2000a. Strontium isotope profile of the early Toarcian (Jurassic) oceanic anoxic event, the duration of ammonite biozones, and belemnite palaeotemperatures. Earth and Planetary Science Letters, 179, 269-285.

McArthur, J.M., Morton, N. \& Thirlwall, M.F. 2000b. Strontium isotope stratigraphy of the Aalenian/Bajocian auxiliary stratotype point at Bearreraig, Isle of Skye, NW Scotland. In: HaLl, R.L. \& Smith, P.L. (eds) Advances in
Jurassic Research 2000. Proceedings of the Fifth International Symposium on the Jurassic System, Vancouver, Canada. GeoResearch Forum, 6, 137-144.

McArthur, J.M., Howarth, R.J. \& Bailey, T.R. 2001. Strontium isotope stratigraphy: LOWESS Version 3: best fit to the marine Sr-isotope curve for 0-509 Ma and accompanying look-up table for deriving numerical age. Journal of Geology, 109, 155-170.

McElwain, J.C., Beerling, D.J. \& Woodward, F.I. 1999. Fossil plants and global warming at the Triassic-Jurassic boundary. Science, 285, 1386-1390.

McRoberts, C.A., Furrer, H. \& Jones, D.S. 1997. Palaeoenvironmental interpretation of a Triassic-Jurassic boundary section from western Austria based on palaeoecological and geochemical data. Palaeogeography, Palaeoclimatology, Palaeoecology, 136, 79-95.

Magoon, L.B. \& Claypool, G.E. 1984. The Kingak Shale of northern Alaskaregional variations in organic geochemical properties and petroleum source rock quality. Organic Geochemistry, 6, 533-542.

Marshall, J.D. 1992. Climatic and oceanographic signals from the carbonate rock record and their preservation. Geological Magazine, 129, 143-160.

Martin, E.E. \& Haley, B.A. 2000. Fossil fish teeth as proxies for seawater $\mathrm{Sr}$ and Nd isotopes. Geochimica et Cosmochimica Acta, 64, 835-847.

MatYja, B.A. \& WierbowsKI, A. 1994. On correlation of Submediterranean and Boreal ammonite zonations of the middle and Upper Oxfordian: new data from central Poland. In: Cariou, E. \& Hantzpergue, P. (eds) 3ème Symposium International de Stratigraphie du Jurassique. Mémoire Special Geobios, 17, 351-358.

Monaco, P., Nocchi, M., Ortega-Huertas, M., Palomo, I., Martinez, F. \& Chiavini, G. 1994. Depositional trends in the Valdorbia Section (Central Italy) during the Early Jurassic, as revealed by micropaleontology, sedimentology and geochemistry. Eclogae Geologicae Helvetiae, 87, 157-223.

Morante, R. \& Hallam, A. 1996. Organic carbon isotopic record across the Triassic-Jurassic boundary in Austria and its bearing on the cause of the mass extinction. Geology, 24, 391-394.

MoRetTinI, E. 1998. Lower Jurassic stable isotope stratigraphy (carbon, oxygen, nitrogen) of the Mediterranean Tethys (Central Italy and southern Spain). Thesis, University of Lausanne.

Morettini, E. \& Bartolini, A. 1999. Stable carbon isotope stratigraphy in the Umbria-Marche and Sabina realm. In: Colacicchi, R., ParisI, G. \& Zamparelli, V. (eds) Bioevents and Integrate Stratigraphy of the Triassic and Jurassic in Italy. Special Publication Palaeopelagos, 3, 131-135.

Morgans-Bell, H.S., Coe, A., Hesselbo, S.P., Jenkyns, H.C., Weedon, G.P., Marshall, J.E.A. \& Williams, C.J. 2001. The stratotype of the Kimmeridge Clay Formation (Upper Jurassic) based on exposures and boreholes in south Dorset, UK. Geological Magazine, 138, 511-539.

MORRIS, K.A. 1980. Comparison of major sequences of organic-rich mud deposition in the British Jurassic. Journal of the Geological Society, London, $137,157-170$

Morton, N. \& Hudson, J.D. 1995. Field guide to the Jurassic of the Isles of Raasay and Skye, Inner Hebrides, NW Scotland. In: TAYLOR, P.D. (ed.) Field Geology of the British Jurassic. Geological Society, London, 209-280.

MucCI, A. 1987. The influence of temperature on the composition of magnesium calcite overgrowths precipitated from seawater. Geochimica et Cosmochimica Acta, 57, 1977-1984.

Murphy, N.J., Sauer, M.J. \& ARmstrong, J.P. 1995. Toarcian source rock potential in the North Celtic Sea Basin, offshore Ireland. In: CRоKеR, P.F. \& Shannon, P.M. (eds) The Petroleum Geology of Ireland's Offshore Basins. Geological Society, London, Special Publications, 93, 193-207.

Naydin, D.P. \& TeYs, R.V. 1976. Oxygen isotope compositions of Eurasian Toarcian-Aalenian seas. Geochemistry International, 13, 163-173.

Nikitenko, B.L. \& Shurygin, B.N. 1992. Lower Toarcian black shades and Pliensbachian-Toarcian crisis of the biota of Siberian paleoseas In: THURston, D.K. \& Fusta, K. (eds) Proceedings, International Conference on Arctic Margins. US Department of the Interior, Anchorage, AK, 39-44.

Nini, C., Nocchi, M. \& Venturi, F. 1996. The Toarcian marly-calcareous succession in the M. Martani area (Northern Apennines): lithostratigraphy, biostratigraphy, paleoecology and effects of Tethysian events on the depositional environment. Bollettino della Società Paleontologica Italiana, 35, $281-319$.

OhKouchi, N., Kawamura, K., Kajiwara, Y., Wada, E., Okada, M., KanamatSU, T. \& TAIRA, A. 1999. Sulfur isotope records around Livello Bonarelli (northern Apennines, Italy) black shale at the Cenomanian-Turonian boundary. Geology, 27, 535-538.

O'Sullivan, K.N.O., IVIMEY-CoOK, H.C., Lewis, B.J. \& HarRison, R.K. 1971. Log of the Llanbedr (Mochras Farm) Borehole. In: WoodLand, A.W. (ed.) The Llanbedr (Mochras Farm) Borehole. Report of the Institute of Geological Sciences, 71/18, 11-35.

PADDEN, M. 2001. Late Jurassic paleoceanography: evidence from stable isotopes and carbonate sedimentology. Thesis, University of Zürich.

Padden, M., Weissert, H. \& DE Rafelis, M. 2001. Evidence for Late Jurassic methane hydrate release: opening of a Pangean gateway. Geology, 29, 
$223-226$

PAGE, K.N. 1992. The sequence of ammonite correlated horizons in the British Sinemurian. Newsletters on Stratigraphy, 27, 129-156.

PAGE, K.N. 1995. East Quantoxhead, Somerset, England; a potential global stratotype section and point (GSSP) for the base of the Sinemurian Stage (Lower Jurassic). Proceedings of the Ussher Society, 8, 446-450.

PÁlfy, J. \& SMith, P.L. 2000. Synchronony between Early Jurassic extinction, oceanic anoxic event, and the Karoo-Ferrar flood basalt volcanism. Geology, 28, 747-750.

Pálfy, J., Demény, A., Hass, J., Hetényi, M., Orchard, M.J. \& Vetö, I. 2001. Carbon isotope anomaly and other geochemical changes at the TriassicJurassic bounary from a marine section in Hungary. Geology, 29, 1047-1050.

Palmer, C.P. 1972. The Lower Lias (Lower Jurassic) between Watchet and Lilstock in North Somerset (United Kingdom). Newsletters on Stratigraphy, $2,1-30$.

PALMER, M.R. \& EDMOND, J.M. 1989. The strontium isotope budget of the modern ocean. Earth and Planetary Science Letters, 92, 11-26.

PAlmer, M.R. \& Elderfield, H. 1985. Sr isotope composition of sea water over the past 75 Myr. Nature, 314, 526-528.

Parisi, G., Baldanza, A., Benedetti, L., Mattioli, E., Venturi, F. \& Cresta, S. 1998. Toarcian stratigraphy of the Colle d'Orlando section (Umbria, Central Italy, northern Apennine). Bollettino della Società Paleontologica Italiana, 37, 3-39.

Parisi, G., Ortega-Huertas, M., Nocchi, M., Palomo, I., Monaco, P. \& MartineZ, F. 1996. Stratigraphy and geochemical anomalies of the early Toarcian oxygen-poor interval in the Umbria-Marche Apennines (Italy). Geobios, 29, 469-484.

PARKInsON, D.N. 1994. The sequence stratigraphy of the Lower Jurassic of Western Europe. D.Phil. thesis, University of Oxford.

Paytan, A., Kastner, M., Campbell, D. \& Thiemens, M.H. 1998. Sulfur isotopic composition of Cenozoic seawater sulfate. Science, 282, 1459-1462.

Pedersen, T.F. \& Calvert, S.E. 1990. Anoxia vs. productivity: what controls the formation of organic-carbon-rich sediments and sedimentary rocks?. AAPG Bulletin, 74, 454-466.

Pegram, W.J., Krishnaswami, S., Ravizza, G.E. \& Turekian, K.K. 1992. The record of seawater ${ }^{187} \mathrm{Os} /{ }^{186} \mathrm{Os}$ variation through the Cenozoic. Earth and Planetary Science Letters, 113, 569-576.

Pettinelli, R., Nocchi, M. \& PARISI, G. 1995. Late Pliensbachian-Toarcian biestratigraphy and environmental interpretations in the Ionian Basin (Lefkas Island, western Greece) as compared to the Umbria-Marchean Basin (Central Italy). Bollettino del Servizio Geologico d'Italia, 114, 97-158.

Peucker-Ehrenbrink, B. \& Ravizza, G. 2000. The marine osmium isotope record. Terra Nova, 12, 205-219.

Peucker-Ehrenbrink, B., Ravizza, G. \& Hoffman, A.W. 1995. The marine ${ }^{187} \mathrm{Os} /{ }^{186} \mathrm{Os}$ record of the past 80 million years. Earth and Planetary Science Letters, 130, 155-167.

Piepgras, D.J. \& JACOBSEN, S.B. 1988. The isotopic composition of neodymium in the North Pacific. Geochimica et Cosmochimica Acta, 52, 1373-1381.

Piepgras, D.J. \& WasserbuRG, G.J. 1980. Neodymium isotopic variations in seawater. Earth and Planetary Science Letters, 50, 128-138.

Piepgras, D.J. \& Wasserburg, G.J. 1987. Rare earth element transport in the western North Atlantic inferred from Nd isotopic observations. Geochimica et Cosmochimica Acta, 51, 1257-1271.

Piepgras, D.J., Wasserburg, G.J. \& Dasch, E.J. 1979. The isotopic composition of $\mathrm{Nd}$ in different ocean masses. Earth and Planetary Science Letters, 45, $223-236$.

Pisera, A., SAtir, M., Gruszczyński, M., Hoffman, A. \& Malkowski, K. 1992. Variation in $\delta^{13} \mathrm{C}$ and $\delta^{18} \mathrm{O}$ in Late Jurassic carbonates, submediterranean province, Europe. Annales Societatis Geologorum Poloniae, 62, 141-147.

Podlaha, O.G., Mutterlose, J. \& Veizer, J. 1998. Preservation of $\delta^{18} \mathrm{O}$ and $\delta^{13} \mathrm{C}$ in belemnite rostra from the Jurassic/early Cretaceous successions. American Journal of Science, 298, 324-347.

Polgári, I.M., Okita, P.M. \& Hein, J.R. 1991. Stable isotope evidence for the origin of the Úrkút manganese ore deposit, Hungary. Journal of Sedimentary Petrology, 61, 384-393.

Prescott, D.M. 1988. The geochemistry and palaeoenvironmental significance of iron pisoliths and ferromanganese crusts from the Jurassic of Mallorca. Eclogae Geologicae Helvetiae, 81, 387-414.

Price, G.D. \& Sellwood, B.W. 1994. Palaeotemperatures indicated by Upper Jurassic (Kimmeridgian-Tithonian) fossils from Mallorca determined by oxygen isotopic composition. Palaeogeography, Palaeoclimatology, Palaeoecology, 110, $1-10$

Pride, C., Thunell, R., Sigman, D., Keigwin, L. \& Altabet, M. 1999. Nitrogen isotopic variations in the Gulf of California since the last deglaciation: response to global climate change. Paleoceanography, 14, 397-409.

Raiswell, R. 1988. Chemical model for the origin of minor limestone-shale cycles by anaerobic methane oxidation. Geology, 16, 641-644.

Ramanampisoa, L. \& DisnaR, J.R. 1994. Primary control of paleoproduction on organic matter preservation and accumulation in the Kimmeridge rocks of Yorkshire. Organic Geochemistry, 21, 1153-1167.

RavizzA, G. 1993. Variations in the ${ }^{187} \mathrm{Os} /{ }^{186} \mathrm{Os}$ ratio of seawater over the past 28 million years as inferred from metalliferous carbonates. Earth and Planetary Science Letters, 118, 335-348.

Ravizza, G. \& Turekian, K.T. 1989. Application of the ${ }^{187} \mathrm{Re}-{ }^{187}$ Os system to black shale geochronometry. Geochimica et Cosmochimica Acta, 53, 3257-3262.

Rees, C.E., Jenkins, W.J. \& Monster, J. 1978. The sulphur isotope composition of ocean water sulphate. Geochimica et Cosmochimica Acta, 42, 377-381.

Renard, M. 1986. Pelagic carbonate chemostratigraphy ( $\left.\mathrm{Sr}, \mathrm{Mg},{ }^{18} \mathrm{O},{ }^{13} \mathrm{C}\right)$. Marine Micropaleontology, 10, 117-164.

Riboulleau, A., Baudin, F., Daux, V., Hantzpergue, P., Renard, M. \& ZaKharov, V. 1998. Évolution de la paléotemperature des eaux de la plateforme russe au cours du jurassique supérieur. Comptes Rendus de l'Académie des Sciences, Paris, Sciences de la Terre et des Planètes, 326, 239-246.

Riegraf, W., Werner, G. \& Lörcher, F. 1984. Der Posidonienschiefer.Biostratigraphie, Fauna und Fazies des südwestdeutschen Untertoarciums (Lias $\mathrm{\epsilon}$ ). F. Enke, Stuttgart.

Robertson, A.H.F. \& OGG, J.G. 1986. Palaeoceanographic setting of the Callovian North Atlantic. In: Summerhayes, C.P. \& Shackleton, N.J. (eds) North Atlantic Palaeoceanography. Geological Society, London, Special Publications, 21, 283-298.

Röhl, J., Schmid-Röhl, A., Oschmann, W., Frimmel, A. \& Schwark, L. 2001 The Posidonia Shale (Lower Toarcian) of SW-Germany: an oxygen-depleted ecosystem controlled by sea level and palaeoclimate. Palaeogeography, Palaeoclimatology, Palaeoecology, 165, 27-52.

RomaneK, C.S., Grossman, E.L. \& Morse, J.W. 1992. Carbon isotopic fractionation in synthetic aragonite and calcite: effects of temperature and precipitation rate. Geochimica et Cosmochimica Acta, 56, 419-430.

Rosales, I., Quesada, S. \& Robles, S. 2001. Primary and diagenetic isotopic signals in fossils and hemipelagic carbonates: the Lower Jurassic of northern Spain. Sedimentology, 48, 1149-1169.

SÆlen, G., Doyle, P. \& Talbot, M.R. 1996. Stable-isotope analyses of belemnite rostra from the Whitby Mudstone Fm, England: surface water conditions during deposition of a marine black shale. Palaios, 11, 97-117.

SÆlen, G., Tyson, R.V., Talbot, M.R. \& Telnæs, N. 1998. Evidence of recycling of isotopically light $\mathrm{CO}_{2}$ (aq) in stratified black shale basins: contrasts between the Whitby Mudstone and Kimmeridge Clay formations, United Kingdom. Geology, 26, 747-750.

SÆlen, G., Tyson, R.V., Telnæs, N. \& Talbot, M.R. 2000. Contrasting watermass conditions during deposition of the Whitby Mudstone (Lower Jurassic) and Kimmeridge Clay (Upper Jurassic) formations, UK. Palaeogeography, Palaeoclimatology, Palaeoecology, 163, 163-196.

Sahagian, D., Pinous, O., Olferiev, A. \& Zakharov, V. 1996. Eustatic curve for the Middle Jurassic-Cretaceous based on Russian Platform and Siberian stratigraphy: zonal resolution. AAPG Bulletin, 80, 1433-1458.

SANDBERG, P.A. 1985. Nonskeletal aragonite and $\mathrm{pCO}_{2}$ in the Phanerozoic and Proterozoic. In: Sundquist, E.T. \& Broecker, W.S. (eds) The Carbon Cycle and Atmospheric $\mathrm{CO}_{2}$. Monograph of the American Geophysical Union, 32, $565-594$.

SCHLANGER, S.O. 1988. Strontium storage and release during deposition and diagenesis of marine carbonates related to sea-level variations. In: LERMAN, A. \& Meybeck, M. (eds) Physical and Chemical Weathering in Geochemical Cycles. NATO ASI Series, 251, 75-119.

Schmid-Röhl, A., RöHl, J., Oschmann, W. \& Frimmel, A. 1999. Der Posidonienschiefer (Lias $€$ ) Südwestdeutschlands: hochauflösende geochemische, palökologische und sedimentologische Untersuchungen. Zentralblatt für Geologie und Paläontologie, 1997, 989-1004.

Scholle, P.A. \& Arthur, M.A. 1980. Carbon isotope fluctuations in Cretaceous pelagic limestones: potential stratigraphic and petroleum exploration tool. AAPG Bulletin, 64, 67-87.

Schouten, S., Van Kaam Peters, H., Rijpstra, W.I.C., Schoell, M. \& Sinninghe Damsté, J. 2000. Effects of an oceanic anoxic event on the stable carbon isotopic composition of Early Toarcian carbon. American Journal of Science, 300, 1-22.

SELlwood, B.W. 1972. Regional environmental changes across a Lower Jurassic stage boundary in Britain. Palaeontology, 15, 124-157.

Shaw, H.F. \& WasserburG, G.J. 1985. Sm-Nd in marine carbonates and phosphates: implications for $\mathrm{Nd}$ isotopes in seawater and crustal ages. Geochimica et Cosmochimica Acta, 49, 503-518.

Sinninghe Damsté, J.S., KoK, M.D., Köster, J. \& Schouten, S. 1998 Sulfurized carbohydrates: an important sink for organic carbon?. Earth and Planetary Science Letters, 164, 7-13.

Soussi, M., Ben Ismail, M.H. \& M'RABET, A. 1990. Les 'black shales' toarciens de Tunisie centrale: témoins d'événement anoxique sur la marge sud téthysienne. Comptes Rendus de l'Académie des Sciences, Paris, Série II, 310, 591-596. 
Spaeth, Ch.r., Hoefs, J. \& Vetter, U. 1971. Some aspects of isotopic composition of belemnites and related paleotemperatures. Geological Society of America Bulletin, 82, 3139-3150.

Spero, H.J., Bijmat, J., Lea, D.W. \& Bemis, B.E. 1997. Effect of seawater carbonate concentration on foraminiferal carbon and oxygen isotopes. Nature, 390, 497-500.

Stein, R., Rullkötter, J. \& Welte, D.H. 1986. Accumulation of organic-rich sediments in the Late Jurassic and early Cretaceous Atlantic Ocean-a synthesis. Chemical Geology, 56, 1-32.

Stevens, G.R. \& Clayton, R.N. 1971. Oxygen isotope studies on Jurassic and Cretaceous belemnites from New Zealand and their biogeographic significance. New Zealand Journal of Geology and Geophysics, 14, 829-897.

Stille, P. \& Fischer, H. 1990. Secular variation in the isotopic composition of $\mathrm{Nd}$ in Tethys seawater. Geochimica et Cosmochimica Acta, 54, 3139-3145.

Stille, P., Clauer, N. \& Abrecht, J. 1989. Nd isotopic composition of Jurassic Tethys seawater and the genesis of Alpine Mn-deposits: evidence from $\mathrm{Sr}-\mathrm{Nd}$ isotope data. Geochimica et Cosmochimica Acta, 53, 1095-1099.

Stille, P., Steinmann, M. \& Riggs, S.R. 1996. Nd isotope evidence for the evolution of the paleocurrents in the Atlantic and Tethys Oceans during the past $180 \mathrm{Ma}$. Earth and Planetary Science Letters, 144, 9-19.

Stoll, H.M. \& Schrag, D.P. 1996. Evidence for glacial control of rapid sea level changes in the Early Cretaceous. Science, 272, 1771-1774.

Stoll, H.M. \& Schrag, D.P. 1998. Effects of Quaternary sea level changes on strontium in seawater. Geochimica et Cosmochimica Acta, 62, 1107-1118.

Stoll, H.M. \& Schrag, D.P. 2000. Coccolith $\mathrm{Sr} / \mathrm{Ca}$ as a new indicator of coccolithophorid calcification and growth rate. Geochemistry Geophysics Geosystems, 1, paper number 1999GC000015.

Stoll, H.M. \& Schrag, D.P. 2001. Sr/Ca variations in Cretaceous carbonates: relation to productivity and sea level changes. Palaeogeography, Palaeoclimatology, Palaeoecology, 168, 311-336.

Stoneley, R. 1987. A review of petroleum source rocks in parts of the middle East. In: Brooks, J. \& Fleet, A.J. (eds) Marine Petroleum Source Rocks. Geological Society, London, Special Publications, 26, 263-269.

Strauss, H. 1999. Geological evolution from isotope proxy signals-sulfur. Chemical Geology, 161, 89-101.

SURLYK, F. 1987. Slope and deep gully sandstones, Upper Jurassic, East Greenland. AAPG Bulletin, 71, 464-475.

Toyoda, K. \& Tokonami, M. 1990. Diffusion of rare-earth elements in fish teeth from deep-sea sediments. Nature, 345, 607-609.

Tribovillard, N.-P. 1988. Géochimie organique et minérale dans les Terres Noires calloviennes et oxfordiennes du bassin dauphinois (France SE): mise en évidence de cycles climatiques. Bulletin de la Société Géologique de France, Série 8, 4, 141-150.

Tribovillard, N.-P., Desprairies, A., Lallier-Verges, E., Bertrand, P., Moureau, N., Ramdani, A. \& Ramanampisoa, L. 1994. Geochemical study of organic-matter rich cycles from the Kimmeridge Clay formation of Yorkshire (UK): productivity versus anoxia. Palaeogeography, Palaeoclimatology, Palaeoecology, 108, 165-181.

URLICHS, M. 1977. The Lower Jurassic in southwestern Germany. Stuttgarter Beiträge zur Naturkunde, Series B (Geologie und Paläontologie), 24, 1-41.

VAKhrameYeV, V.A. 1982. Classopolis pollen as an indicator of Jurassic and Cretaceous climate. International Geological Review, 24, 1190-1196.

VAN KAAM-Peters, H.M.E. 1997. The depositional environment of Jurassic organic-rich sedimentary rocks in NW Europe. A biomarker approach. Geologica Ultraiectiana, Mededelingen van de Faculteit Aardwetenschappen Universiteit Utrecht, 153.

Van Kaam-Peters, H.M.E., Schouten, S., Köster, J. \& Sinninghe Damsté, J.S. 1998. Controls on the molecular and carbon isotopic composition of organic matter deposited in a Kimmeridgian euxinic shelf sea: evidence for preservation of carbohydrates through sulfurisation. Geochimica et Cosmochimica Acta, 62, 3259-3283.

VeIZer, J. 1974. Chemical diagenesis of belemnite shells and possible consequences for paleotemperature determinations. Neues Jahrbuch für Geologie und Paläontologie, Abhandlungen, 147, 91-111.

Veizer, J. \& Fritz, P. 1976. Possible control of post-depositional alteration in oxygen paleotemperature determinations. Earth and Planetary Science Letters, 33, 255-260.

Veizer, J., Ala, D., Azmy, K. \& 12 others $1999 .{ }^{87} \mathrm{Sr} /{ }^{86} \mathrm{Sr}, \delta^{13} \mathrm{C}$ and $\delta^{18} \mathrm{O}$ evolution of Phanerozoic seawater. Chemical Geology, 161, 59-88.

Veizer, J., Buhl, D., Diener, A. \& 8 others 1997. Strontium isotope stratigraphy: potential resolution and event correlation. Palaeogeography, Palaeoclimatology, Palaeoecology, 132, 65-77.

Vetö, I., Demény, A., Hertelendi, E. \& Hetényi, M. 1997. Estimation of primary productivity in the Toarcian Tethys - a novel approach based on TOC, reduced sulphur and manganese contents. Palaeogeography, Palaeoclimatology, Palaeoecology, 132, 355-371.

Ward, P.D., Haggart, J.W., Carter, E.S., Wilbur, D., Tipper, H.W. \& Evans, T. 2001. Sudden productivity collapse associated with the Triassic-Jurassic boundary mass extinction. Science, 292, 1148-1151.

Weedon, G.P. \& Jenkyns, H.C. 1990. Regular and irregular climatic cycles and the Belemnite Marls (Pliensbachian, Lower Jurassic, Wessex Basin). Journal of the Geological Society, London, 147, 915-918.

Weedon, G.P. \& Jenkyns, H.C. 1999. Cyclostratigraphy and the Early Jurassic timescale: data from the Belemnite Marls, Dorset, Southern England. Geological Society of America Bulletin, 111, 1823-1840.

Weissert, H. \& Channell, J.E.T. 1989. Tethyan carbon isotope stratigraphy across the Jurassic-Cretaceous boundary: an indicator of decelerated carbon cycling. Paleoceanography, 4, 483-494.

Weissert, H. \& Mohr, H. 1996. Late Jurassic climate and its impact on carbon cycling. Palaeogeography, Palaeoclimatology, Palaeoecology, 122, 27-43.

WiErzBowsKi, H. 2002. Detailed oxygen and carbon isotope stratigraphy of the Oxfordian in Central Poland. Internatioanl Journal of Earth Sciences (Geologische Rundschau), 91, 304-314.

Wilkinson, B.H. \& Algeo, T.J. 1989. Sedimentary carbonate record of calciummagnesium cycling. American Journal of Science, 289, 1158-1194.

Williams, C.J., Hesselbo, S.P., Jenkyns, H.C. \& Morgans-Bell, H.S. 2001. Quartz silt in mudrocks as a key to sequence stratigraphy (Kimmeridge Clay Formation, Late Jurassic, Wessex Basin, UK). Terra Nova, 13, $449-455$.

Woodfine, R., Jenkyns, H.C., SARti, M., Bruni, R. \& Baroncini, F. 2001. Stable-isotope analysis of Italian shallow-water carbonates: the response of Mesozoic platform carbonates to Oceanic Anoxic Events. EOS Transactions, American Geophysical Union, Fall Meeting Supplement, 82, Abstract PP32A01512 .

YAPP, C.Y. \& Poths, H. 1996. Carbon isotopes in continental weathering environments and variations in ancient atmospheric $\mathrm{CO}_{2}$. Earth and Planetary Science Letters, 137, 71-82.

Yasamanov, N.A. 1981. Paleothermometry of Jurassic, Cretaceous, and Paleogene periods of some regions of the USSR. International Geology Review, 23, $700-706$.

Zachos, J.C., Stott, L.D. \& Lohmann, K.C. 1994. Evolution of early Cenozoic marine temperatures. Paleoceanography, 9, 353-387.

Zempolich, W.G. \& Erba, E. 1999. Sedimentologic and chemostratigraphic recognition of third-order sequences in resedimented carbonate: the Middle Jurassic Vajont Limestone. In: Harris, P.M., Saller, A.H. \& Simo, J.A. (eds) Advances in Carbonate Sequence Stratigraphy: Application to Reservoirs, Outcrops and Models. SEPM (Society for Sedimentary Geology) Special Publication, 63, 335-370. 